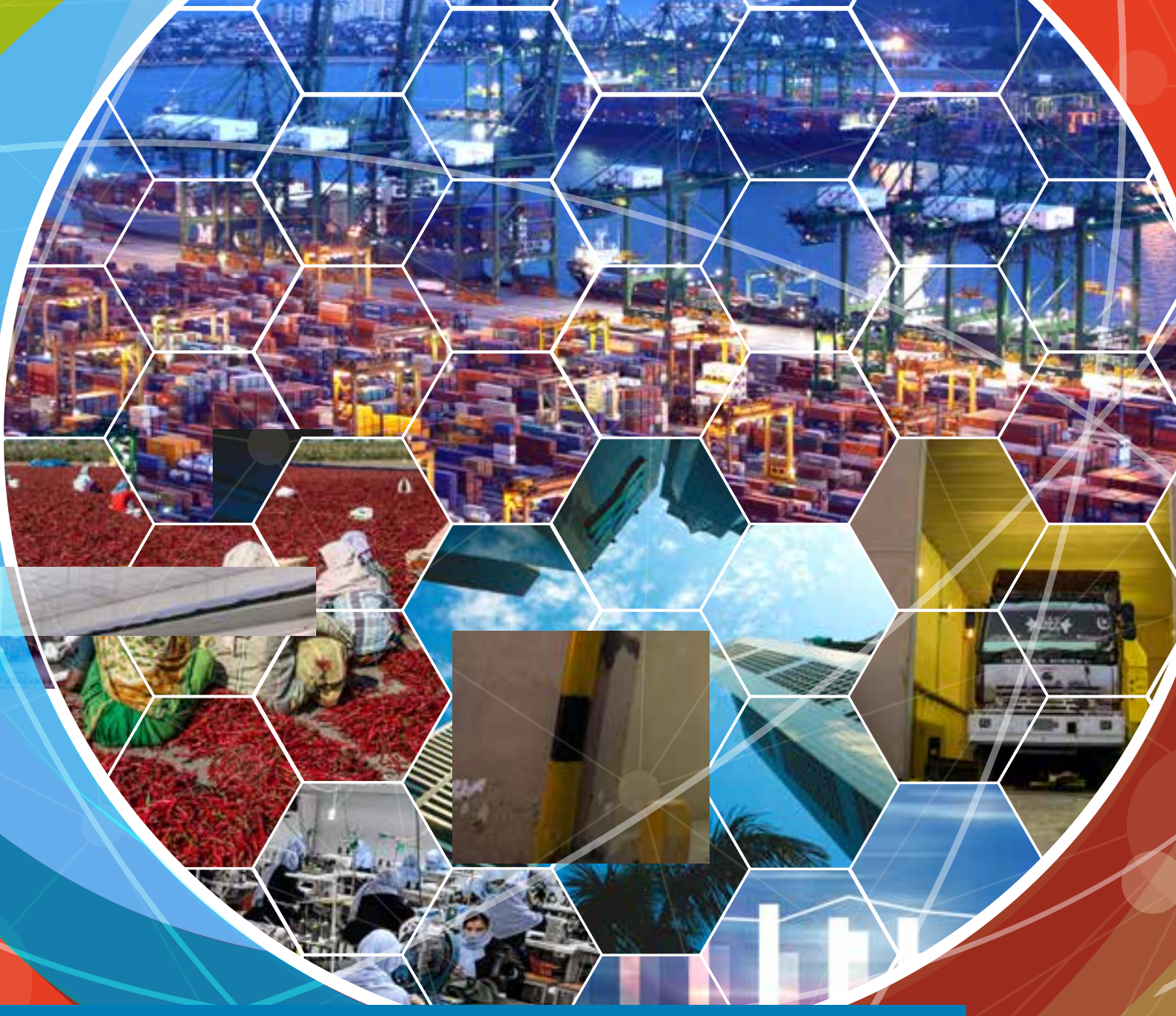

TRADE FACILITATION AND

BETTER CONNECTIVITY

FOR AN INCLUSIVE ASIA

AND PACIFIC 



\section{TRADE FACILITATION AND BETTER CONNECTIVITY FOR AN INCLUSIVE ASIA AND PACIFIC}


(c) 2017 Asian Development Bank

6 ADB Avenue, Mandaluyong City, 1550 Metro Manila, Philippines

Tel +632632 4444; Fax+6326362444

www.adb.org

UNESCAP has granted permission to to use UNESCAP-copyrighted material for this Work, and to make the material available under an open access license.

Some rights reserved. Published in 2017.

ISBN 978-92-9257-933-3 (Print), 978-92-9257-934-0 (e-ISBN)

Publication Stock No. TCS178988-2

http://dx.doi.org/10.22617/TCS178988-2

The views expressed in this publication are those of the authors and do not necessarily reflect the views and policies of the Asian Development Bank (ADB) or its Board of Governors or the governments they represent.

ADB does not guarantee the accuracy of the data included in this publication and accepts no responsibility for any consequence of their use. The mention of specific companies or products of manufacturers does not imply that they are endorsed or recommended by ADB in preference to others of a similar nature that are not mentioned.

By making any designation of or reference to a particular territory or geographic area, or by using the term "country" in this document, ADB does not intend to make any judgments as to the legal or other status of any territory or area.

This work is available under the Creative Commons Attribution 3.0 IGO license (CC BY 3.0 IGO)

https://creativecommons.org/licenses/by/3.0/igo/. By using the content of this publication, you agree to be bound by the terms of this license. For attribution, translations, adaptations, and permissions, please read the provisions and terms of use at https://www.adb.org/terms-use\#openaccess

This CC license does not apply to non-ADB copyright materials in this publication. If the material is attributed to another source, please contact the copyright owner or publisher of that source for permission to reproduce it. ADB cannot be held liable for any claims that arise as a result of your use of the material.

Please contact pubsmarketing@adb.org if you have questions or comments with respect to content, or if you wish to obtain copyright permission for your intended use that does not fall within these terms, or for permission to use the ADB logo.

Notes:

In this publication, "\$” refers to US dollars.

Corrigenda to ADB publications may be found at http://www.adb.org/publications/corrigenda 


\section{CONTENTS}

Acknowledgments $\quad v$

Abbreviations

Highlights $\quad$ vii

1. Introduction 1

2. Trade Facilitation and Paperless Trade in Asia and the Pacific: State of Play 4

2.1 Trade costs 4

2.2 Implementation of Trade Facilitation and Paperless Trade Measures 6

2.2.1 Status of implementation 6

2.2.2 Implementation progress from 2015 to 2017

2.3 Subregional Cooperation Initiatives and Trade Facilitation in Asia and the Pacific 14

2.3.1 Central Asia Regional Economic Cooperation Program 14

2.3.2 Greater Mekong Subregion Program 16

2.3.3 South Asia Subregional Economic Cooperation Program 18

2.3.4 The Pacific 20

3. Assessing Impacts of Trade Facilitation 22

3.1 Trade Facilitation Impact on Trade Costs: Evidence from Asia and the Pacific 22

3.1.1 Trade cost model and data 22

3.1.2. Regression analysis results 22

3.1.3. Simulation analysis 25

3.1.4. Summary 27

3.2 Trade Facilitation Impact on Trade Flows: Evidence from Central Asia 27

3.2.1. Background: Trade facilitation indicators in Central Asia Regional Economic Cooperation 27

3.2.2. Methodology: Gravity model 28

3.2.3. Data for analysis 30

3.2.4. Estimation results 31

3.2.5. Simulation exercise 32

3.2.6 Summary

4. Challenges and the Way Forward 37

$\begin{array}{ll}\text { Appendix } & 39\end{array}$

$\begin{array}{ll}\text { References } & 41\end{array}$ 


\section{Figures}

Figure 1: The Four Pillars and Five Key Areas of Trade Facilitation 1

Figure 2: Impact of Trade Facilitation $\quad 2$

Figure 3: Trade Costs of Asia and Pacific Subregions with Large Developed Economies 5

Figure 4: Overall Implementation of Trade Facilitation Measures in 44 Asia and Pacific Countries 9

Figure 5: Trade Facilitation Implementation Across Asia and Pacific Subregions and Countries with Special Needs 9

Figure 6: Implementation of Different Groups of Trade Facilitation Measures 10

Figure 7: Trade Facilitation Implementation in 2015 and 2017

Figure 8: Implementation of Different Groups of Trade Facilitation Measures in 2015 and 2017

Figure 9: The Central Asia Regional Economic Cooperation Corridors $\quad 15$

Figure 10: The Greater Mekong Subregion Economic Corridors 17

Figure 11: The South Asia Subregional Economic Cooperation Economic Corridors 19

Figure 12: Diagram for Border Crossing Point Data Structure 31

Figure 13: Moving up the Trade Facilitation Ladder Toward Seamless International Supply Chains 38

\section{Tables}

Table 1: Intraregional and Extra-Regional Comprehensive Trade Costs in Asia and the Pacific (excluding tariff costs), 2010-2015 5

Table 2: Grouping of Trade Facilitation Measures Included in the Questionnaire $\quad 7$

Table 3: Most and Least Implemented Measures in Asia and the Pacific 11

Table 4: Impact of Trade Facilitation Measures at the Subregional Level Trade Facilitation Measure Impact 18

Table 5: Description of Variables in the Model 23

Table 6: Trade Cost Model Results $\quad 24$

Table 7: International Trade Cost Changes in Asia and the Pacific Resulting from WTO TFA Implementation 26

Table 8: Trade Cost Changes in Asia and the Pacific Resulting from Port Connectivity and Trade Finance Improvement $\quad 26$

Table 9: Corridor Performance Measurement and Monitoring Trade Facilitation Indicators 28

Table 10: Variables in the Gravity Model $\quad 29$

Table 11: Gravity Model Estimation: Time Taken (hours) at Border Crossing Points (road) on Bilateral Exports 33

Table 12: Gravity Model Estimation: Impact of Average Cost (in US\$) at BCPs (road) on Bilateral Exports 34

Table 13: Trade Gains from Time Reduction at Border Crossing Points 35

\section{Boxes}

Box 1: Estimated Gains from Trade Facilitation 3

Box 2: The World Trade Organization's Trade Facilitation Agreement 6

Box 3: The Economic and Social Commission for Asia and the Pacific Framework Agreement on Facilitation of Cross-Border Paperless Trade 13

Box 4: Toward a National Integrated and Sustainable Trade and Transport Facilitation Monitoring Mechanism 21 


\section{ACKNOWLEDGMENTS}

This report was jointly prepared by the Regional Cooperation and Integration Division of the Economic Research and Regional Cooperation Department, the Asian Development Bank (ADB), and Trade, Investment and Innovation Division, the United Nations Economic and Social Commission for Asia and the Pacific (ESCAP).

Cyn-Young Park, Director of the Regional Cooperation and Integration Division, ADB and Yann Duval, Chief a.i. of Trade Policy and Facilitation, Trade, Investment and Innovation Division, ESCAP led the preparation of this publication.

The main contributors from ADB included Kijin Kim and Aleli Rosario. Paulo Halili, Carolyn Ongchangco, and Maria Criselda Aherrera provided additional inputs and administrative support. A group of consultants, namely, Regina Villasor, Paul Mariano, Benjamin Endriga, and Zemma Ardaniel provided research support. Ying Qian and Julius Santos supported the analysis of trade facilitation in the Central Asia Regional Economic Cooperation region by providing the data and consultation.

The main contributors from the ESCAP included Tengfei Wang, Yann Duval, and Chorthip Utoktham, with support from Agathe Blanchard during her internship at ESCAP. Financial support from the Ministry of Finance, the Republic of Korea, for conducting the survey and disseminating the results is gratefully acknowledged.

Eric Van Zant edited the manuscript and Erickson Mercado typeset it and designed the cover and graphics. The Printing Services Unit of ADB's Office of Administrative Services and the Publishing Team of the Department of External Relations supported printing and publishing. 


\section{ABBREVIATIONS}

ADB

ASEAN

AUS

BCP

BIMSTEC

BPA

CAREC

CEPII

CPMM

ESCAP

EU

GDP

GMS

$\mathrm{LSCl}$

NZL

OECD

PRC

$\mathrm{RCl}$

SAARC

SASEC

SDGs

SMES

SPS

TFA

TFI

UN

UN/CEFACT United Nations Centre for Trade Facilitation and Electronic Business

UNCTAD United Nations Conference on Trade and Development

UNDP

WTO

Asian Development Bank

Association of Southeast Asian Nations

Australia

border crossing point

Bengal Initiative for Multi-Sectoral Technical and Economic Cooperation

business process analysis

Central Asia Regional Economic Cooperation

Centre d'Études Prospectives et d'Informations Internationales

corridor performance measurement and monitoring

Economic and Social Commission for Asia and the Pacific

European Union

gross domestic product

Greater Mekong Subregion

liner shipping connectivity index

New Zealand

Organisation for Economic Co-operation and Development

People's Republic of China

regional cooperation and integration

South Asian Association for Regional Cooperation

South Asia Subregional Economic Cooperation

sustainable development goals

small and medium-sized enterprises

sanitary and phytosanitary

trade facilitation agreement

trade facilitation indicators

United Nations

United Nations Development Programme

World Trade Organization 


\section{HIGHLIGHTS}

- Trade facilitation has emerged as a key instrument for further reducing trade costs. While tariff rates have come down substantially across Asia and the Pacific, non-tariff barriers remain significant. Trade facilitation improves trade efficiency and lowers transaction costs. With the decline of tariffs over the last 2 decades, the real impediments to trade are non-tariff and technical barriers. Trade facilitation also offers more practical solutions for stimulating trade and economic growth amid the fallout from the Trans-Pacific Partnership trade agreement.

- Trade costs have fallen in Asia and the Pacific since 1996, but still vary widely across subregions. East Asia has the lowest trade costs in the region, continuing a downward trend. Trade costs in the Russian Federation and Central Asia remained high but have declined dramatically and steadily over the past decade, putting them nearly at par with those of the South Asian economies. The Pacific has the highest, but their trend is clearly downward.

- The 2017 global survey on trade facilitation and paperless trade implementation reveals improvement across Asia and the Pacific. The survey covers 47 trade facilitation measures divided into seven groups-(i) general trade facilitation measures including transparency formalities, and institutional arrangement and cooperationv; (ii) paperless trade; (iii) cross-border paperless trade; (iv) transit facilitation; ( $v$ ) trade facilitation for small and medium-sized enterprises (SMEs); (vi) agricultural trade facilitation; and (vii) women in trade facilitation. ${ }^{a}$ Key findings include the following:

- The average implementation rate on (i) general trade facilitation, (ii) paperless trade, and (iii) cross-border paperless trade improved to $50.4 \%$ in 2017 from 46.5\% in 2015 for Asia and the Pacific.

- The implementation rates vary widely across subregions and within each subregional group. Apart from Australia and New Zealand, average implementation is highest in East Asia (73.7\%), followed by Southeast Asia and Timor-Leste (60.1\%), the Russian Federation and Central Asia (51.8\%), and South Asia and Turkey (46.5\%). The Pacific lags at 28.2\%.

- The region's implementation rates on (i) general trade facilitation and (iv) transit facilitation-mostly covered by the World Trade Organization's Trade Facilitation Agreement (WTO TFA) - are relatively high, at 50\%-70\%. However, areas such as cross-border paperless trade remain at an early stage.

- Average implementation rates in (v) trade facilitation for SMEs are low at 39\% and (vii) women in trade facilitation, at 23\%, suggesting a need for further support in these areas.

- Full implementation of the WTO TFA could reduce trade costs by $9 \%$. Scenario analysis of the impact of trade facilitation implementation in Asia and the Pacific reveals that:

a The first global survey was conducted in 2015 to assess the implementation status of trade facilitation worldwide. The second global survey, in 2017 , draws on the final list of provisions under the World Trade Organization Trade Facilitation Agreement and the text of the regional United Nations treaty on cross-border paperless trade facilitation. Each trade facilitation measure is rated either "fully implemented", "partially implemented", "on a pilot basis", or "not implemented" with scores of 3, 2, 1, or 0 . Further information of the survey is available at https://unnext.unescap.org/content/global-survey-trade-facilitation-and-paperless-trade-implementation-2017 
- Implementing the WTO TFA measures could reduce trade costs by $5 \%$ under partial implementation, and $9 \%$ under full implementation.

- If paperless and cross-border paperless trade measures are implemented in addition to the WTO TFA measures, trade costs could be reduced by up to $16 \%$.

- Subregional cooperation initiatives including the Central Asia Regional Economic Cooperation (CAREC) contribute significantly to reducing trade costs and increasing intra-regional trade volume. Empirical analysis of corridor performance on reducing trade costs and increasing trade in the subregion covered by the CAREC program shows that:

- Average time (hours) taken at a border crossing is a more significant factor than average costs (US dollar) at a border in determining bilateral trade flows within the region.

- A $10 \%$ reduction in time at the importers' border raises intra-CAREC trade by $2 \%-3 \%$, for a $\$ 1.4$ billion increase in intraregional trade.

- Institutional coordination is essential for successful trade facilitation.

Commitment and consistency are required for all stakeholders on policies, operating systems, and institutions. Improving the business climate and governance is also a critical condition to maximize trade facilitation results.

- Going forward, digitalization offers great potential to enhance trade facilitation implementation and further reduce trade costs in Asia and the Pacific.

- Trade facilitation implementation follows a step-by-step process: (1) setting up the institutional arrangement, (2) ensuring more transparent trade processes, (3) designing and implementing simpler and more efficient trade formalities, (4) developing paperless trade systems, and (5) achieving crossborder paperless trade.

- The United Nations treaty, the "Framework Agreement on Facilitation of Cross-Border Paperless Trade in Asia and the Pacific", which complements the WTO TFA by facilitating paperless trade, can provide a unique opportunity for participating countries to boost trade and investment competitiveness and support the growth of their digital economies. The treaty aims to enable the electronic exchange of trade-related data and documents across borders. 


\section{INTRODUCTION*}

Trade helps drive inclusive growth and poverty reduction. Strong value added from trade-related activities contributes to economic growth and development in developing Asia. Global trade helps reallocate capital and labor toward sectors with comparative advantage. And international trade is one important way to help meet the United Nations Sustainable Development Goals (SDGs). The beneficial links between trade and investment catalyzes economic transformation, job creation, and skill development-which all support SDG 8 (promoting decent work and economic growth), SDG 9 (building resilient infrastructure, promoting inclusive and sustainable industrialization and fostering innovation), SDG 10 (reducing inequality within and among countries), and SDG 17 (revitalized and enhanced global partnership) (Kituyi 2016).

Trade facilitation eases the cross-border movement of goods by cutting costs and simplifying trade procedures (OECD 2005). It rests on four pillars: (i) transparency, (ii) simplification, (iii) harmonization, and (iv) standardization. Transparency promotes openness and accountability; it involves publicizing easily understood regulations so stakeholders can provide feedback prior to enforcement. Simplification eliminates unnecessary elements and duplications, focusing on essential aspects of trade and critical processes. Harmonization aligns national procedures, operations, and documents among trading partners. And standardization aims to develop international best practices (UNECE 2012).

Based on these principles, trade facilitation focuses on five areas: (i) publicizing and administering policies related to trade issues, (ii) establishing rules and procedures for import and export, (iii) creating product standards that conform to World Trade Organization (WTO) guidelines on standards, (iv) building traderelated infrastructure and supplying quality services that effectively reduce trade costs, and (v) balancing rapid customs clearance with adequate security and protection from fraud (ADB 2013, Figure 1).

Figure 1: The Four Pillars and Five Key Areas of Trade Facilitation
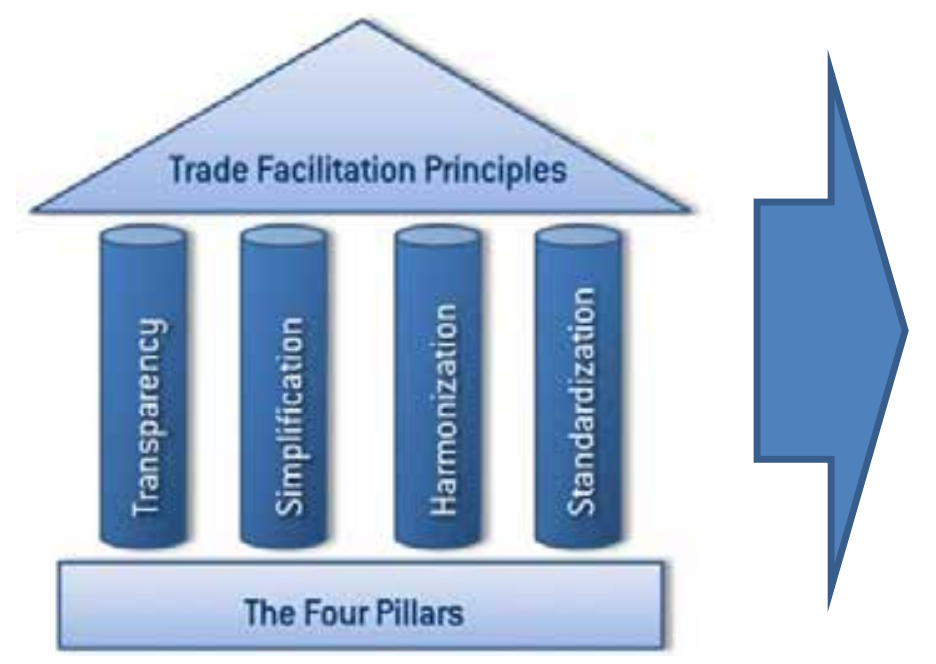
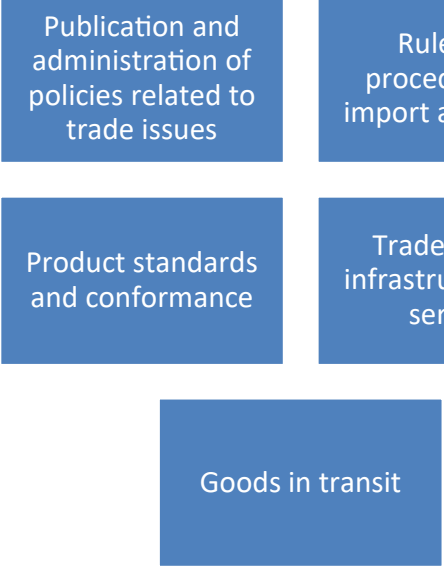

Sources: National Board of Trade, Sweden; ADB (2013).

\footnotetext{
* This section draws mostly on ADB (2017a), and the latest data available were updated or added.
} 
Trade facilitation particularly benefits landlocked and island countries, where it boosts participation in international supply chains. They can diversify production of intermediate and final goods to cater to the global market, benefiting other regions as well.?

Indeed, everyone gains from easier trading processes (OECD 2005) - trade facilitation raises government revenues by reducing fraud; businesses become more competitive and efficient, raising profits; and consumers save from lower prices. Inefficient trade procedures add significant costs, usually shouldered by the taxpayer or buyer, and it makes investment less attractive.

Trade facilitation increases trade flows and ultimately helps achieve sustainable and inclusive growth (Figure 2). It lowers direct costs by raising efficiency among interacting businesses and administering agencies. Prices fall as they indirectly benefit from simpler, transparent border procedures. Even modest cost reductions show a positive link between trade facilitation and increased trade. All countries stand to gain, especially the developing ones, and those that improve border procedures will benefit most.

\section{Figure 2: Impact of Trade Facilitation}

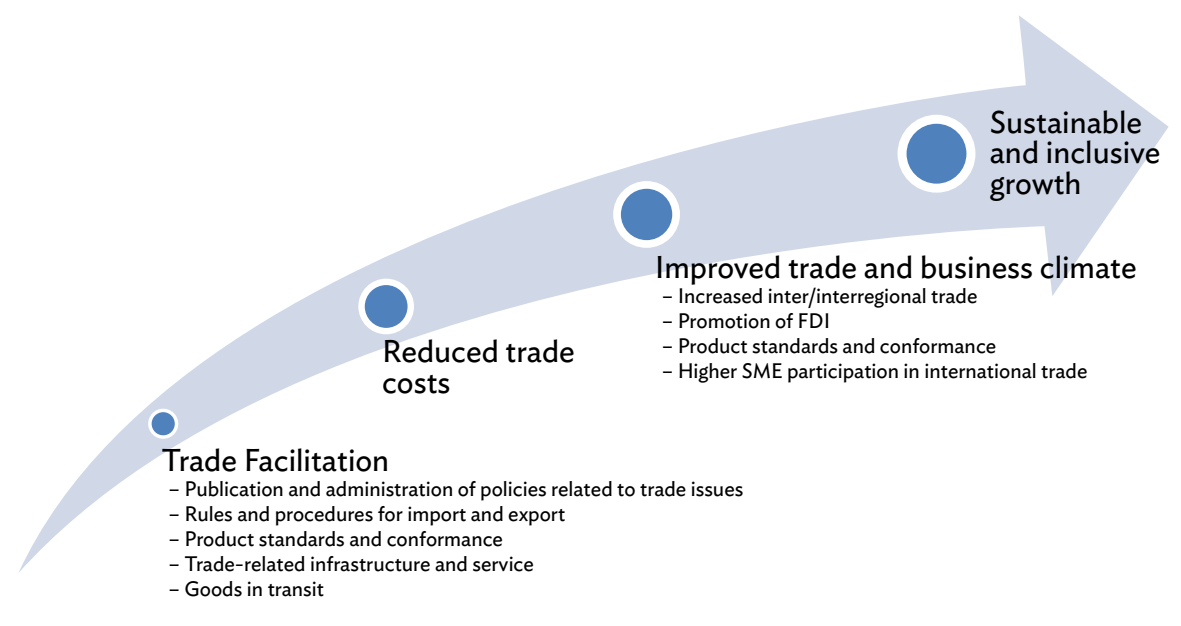

$\mathrm{FDI}=$ foreign direct investment, $\mathrm{SME}=$ small and medium-sized enterprises. Source: Authors.

Trade facilitation can have a greater impact on specific product groups, firms, and economies (Box 1). For example, agro-food products have higher cross-border costs than manufactured goods, as they are subjected to special border procedures (costing 1\%-15\% of product value). Long border delays raise final costs by increasing spoilage.

Small and medium-sized enterprises (SMEs) are more vulnerable to financial and efficiency costs than large enterprises. The larger the international trade within a firm, the more economies of scale and comparative advantage exist for logistics and administrative coordination. In a highly competitive environment, SMEs have to address the constraints of limited human resources, information, and capital. They are also often classified as high-risk and are required to comply with additional documentation and cargo checks.

This is especially true for non-OECD countries with high trade-to-gross-domestic-product (GDP) ratios - and thus highly sensitive to changes in import and export costs. Developing countries would likely gain from trade facilitation. Those best able to ease border flows with minimal financial resources show how small investments in trade facilitation can bring high relative returns. Additional investments would amplify the benefits.

1 Developing countries in East Asia and Southeast Asia accounted for approximately 40\% of global supply chain trade in 2015, compared with 34\% for the European Union (EU), 10\% for the United States (US), and 5\% for Japan (Daily Mirror 2017). 
This report is constructed as follows. Chapter 2 reviews the evolution of trade costs in the region, examines trade facilitation and paperless trade implementation, and highlights key initiatives and efforts in Central Asia, the Greater Mekong Subregion, South Asia, and the Pacific. Chapter 3 analyzes in-depth the impact assessments of trade facilitation implementation and corridor performance on reducing trade costs and increasing trade. Chapter 4 concludes by examining the challenges in implementing trade facilitation measures, presenting the way forward.

\section{Box 1: Estimated Gains from Trade Facilitation}

Benefits from trade facilitation vary across economies, enterprises, and product groups.

\section{Across economies}

- In developed economies, efficiency gains and savings are still achieved:

- Japan: waiting time and incurred costs were lessened by transitioning from paper to electronic data interchange. This translated to a $50 \%$ reduction in the number of application forms to be filled out and $200 \%$ reduction in the number of items for general declaration from 2001 to 2005.

- New Zealand: the number of trade transactions has significantly increased from 1 million import entries in 2000 to 4 million in 2011 after the implementation of risk management system ${ }^{1}$ in its customs transactions.

- Singapore: the single-window system helped minimize documentation costs by more than half. Trade documentation fees went down to as low as $\$ 1.80$ per application in 2010 from $\$ 6.25$ before the TradeNet ${ }^{2}$ implementation in 1989.

- In developing countries:

- Bangladesh: the number of signatures required for export and import clearance declined significantly from 25 in 1999 to five in 2014.

- Thailand: the implementation of the National Single Window in 2008 brought savings of about $\$ 1.5$ billion annually and cut the time to export from 17 days to 14 days.

\section{Enterprises}

- In the Philippines, electronic lodgment which started in October 2007 had helped transactions of small and medium-sized enterprises (SMEs) become convenient and efficient through reduced cost and time.

- The customs automation system in Bangladesh implemented in October 2008 has increased SMEs' integration into international trade, made document processing for exports faster, and improved the goodwill and business reputations of SMEs.

- For large firms in the Republic of Korea, implementation of information technology ${ }^{3}$ to cargo clearance led to significant cost reductions and substantial reduction, if not eliminate, customs and cargo clearance divisions. SMEs were also able to save labor costs and costs associated with opening trade documents.

\section{Product groups}

- GrapeNet software, launched in India in 2006 , to meet international standards and provide traceability of grape exports allowed importers to access certificate-issuing authorities, check inspection reports, laboratory analysis, certificate of residue analysis and other details related to the particular produce boosting India's exports to the European Union and raising importers' confidence.

- In Greece, the automated risk-based control in agricultural exports implemented in 2011, significantly reduced the time needed for exports to non-EU countries and the number of inspections while maintaining high-quality of agricultural exports.

1 The comprehensive risk management system allowed customs to assess risks for all transactions within minutes of an entry being made and in advance of the physical arrival of goods.

2 TradeNet is the national single window system of Singapore.

3 Information technology involves hardware/software installation, replacement of paper forms with electronic ones, and revisions related to laws and regulations.

Sources: UNNExT (2010, 2011, 2012, 2014, 2015), Farhad (2014), WTO (2011), De Dios (2009), Yang (2009), Syed, et al. (2009). 


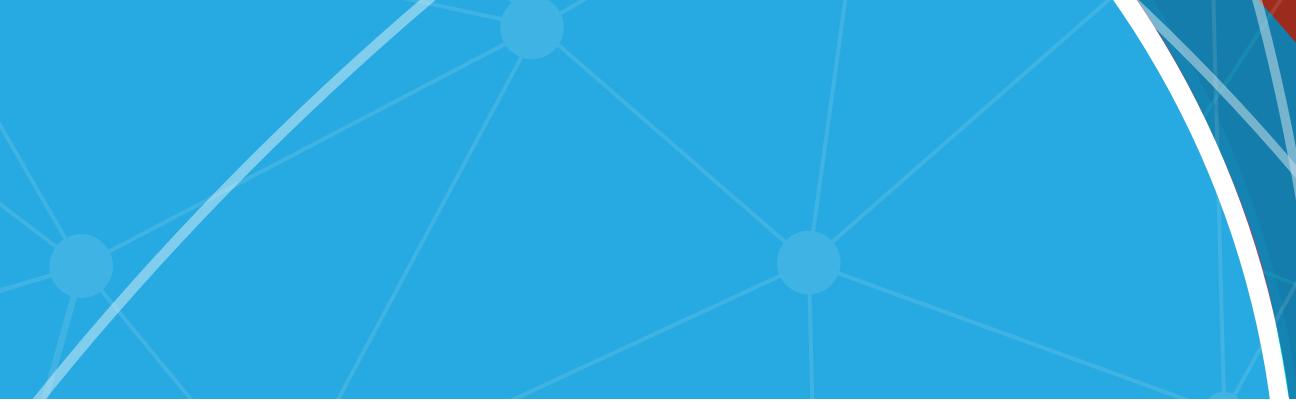

\section{TRADE FACILITATION AND PAPERLESS TRADE IN ASIA AND THE PACIFIC: STATE OF PLAY*}

\subsection{Trade costs ${ }^{2}$}

According to the latest data from the ESCAP-World Bank International Trade Cost Database (Table 1), the overall cost of trading goods among the three largest European Union (EU) economies is equivalent to a $42 \%$ average tariff on the value of goods traded. The People's Republic of China (PRC), Japan, and the Republic of Korea (East Asia-3) come closest to matching intra-EU trade costs (51\% tariff equivalent), followed by middle-income Association of Southeast Asian Nations (ASEAN) members (76\% tariff equivalent). Countries in South Asia, including Bhutan, face the region's highest trade costs (186\% tariff equivalent).

Figure 3 shows the evolution of trade costs of the Asia and Pacific subregions in trading with the three largest developed economies from 1996 to 2014. ${ }^{3}$ Trade costs in the region have generally declined slowly, but still vary widely across subregions. East Asia-3 has the lowest trade costs and the Russian Federation and the Central Asian economies have maintained a declining trend and now have trade costs comparable to the ones of the South Asian economies (South Asian Association for Regional Cooperation [SAARC] SAARC-4). Trade costs remain highest in the Pacific, although trade costs there are clearly trending downward.

Chapter 2 draws mostly on ESCAP (2015), and the latest data available were updated or added.

2 In sections 2.1 and 2.2, regional and income groupings used in the global survey on trade facilitation are defined as follows: East Asia includes People's Republic of China, Japan, the Republic of Korea, and Mongolia; Central Asia includes- Armenia, Azerbaijan, Kazakhstan, Kyrgyz Republic, Tajikistan, and Uzbekistan; The Pacific includes Fiji, Kiribati, Federated States of Micronesia, Nauru, Palau, Papua New Guinea, Samoa, Solomon Islands, Tonga, Tuvalu, and Vanuatu; South Asia includes Afghanistan, Bangladesh, Bhutan, India, Maldives, Nepal, Pakistan, and Sri Lanka; Southeast Asia includes Brunei Darussalam, Cambodia, Indonesia, Lao People’s Democratic Republic (Lao PDR), Malaysia, Myanmar, Philippines, Singapore, Thailand, and Viet Nam; landlocked developing countries include Afghanistan, Armenia, Azerbaijan, Bhutan, Kazakhstan, Kyrgyz Republic, Lao PDR, Mongolia, Nepal, Tajikistan, and Uzbekistan; least developed countries include Afghanistan, Bangladesh, Bhutan, Cambodia, Kiribati, Lao PDR, Myanmar, Nepal, Solomon Islands, Timor-Leste, Tuvalu, and Vanuatu; small island developing states include Fiji, Kiribati, Maldives, Federated States of Micronesia, Nauru, Palau, Papua New Guinea, Samoa, Solomon Islands, Timor-Leste, Tonga, Tuvalu, and Vanuatu.

3 This is done using bilateral aggregate trade cost data from the ESCAP-World Bank Database (2017). 
Table 1: Intraregional and Extra-Regional Comprehensive Trade Costs in Asia and the Pacific (excluding tariff costs), 2010-2015

\begin{tabular}{|c|c|c|c|c|c|c|c|}
\hline Region & ASEAN-4 & East Asia-3 & $\begin{array}{l}\text { Russian } \\
\text { Federation } \\
\text { and Central } \\
\text { Asia-4 }\end{array}$ & Pacific & SAARC-4 & AUS-NZL & EU-3 \\
\hline ASEAN-4 & $\begin{array}{r}76 \% \\
(6.7 \%)\end{array}$ & & & & & & \\
\hline East Asia-3 & $\begin{array}{r}76 \% \\
(4.1 \%)\end{array}$ & $\begin{array}{r}51 \% \\
(-2.9 \%)\end{array}$ & & & & & \\
\hline $\begin{array}{l}\text { Russian Federation and } \\
\text { Central Asia - } 4\end{array}$ & $\begin{array}{r}343 \% \\
(5.4 \%)\end{array}$ & $\begin{array}{r}167 \% \\
(-9.9 \%)\end{array}$ & $\begin{array}{r}116 \% \\
(-0.9 \%)\end{array}$ & & & & \\
\hline Pacific & $\begin{array}{r}172 \% \\
(-9.0 \%)\end{array}$ & $\begin{array}{r}173 \% \\
(-3.1 \%)\end{array}$ & $\begin{array}{r}370 \% \\
(21.6 \%)\end{array}$ & $\begin{array}{r}130 \% \\
(-8.8 \%)\end{array}$ & & & \\
\hline SAARC-4 & $\begin{array}{r}130 \% \\
(3.5 \%)\end{array}$ & $\begin{array}{r}123 \% \\
(-2.1 \%)\end{array}$ & $\begin{array}{l}302 \% \\
(7.7 \%)\end{array}$ & $\begin{array}{r}300 \% \\
(-4.6 \%)\end{array}$ & $\begin{array}{r}119 \% \\
(12.9 \%)\end{array}$ & & \\
\hline AUS-NZL & $\begin{array}{r}101 \% \\
(2.9 z \%)\end{array}$ & $\begin{array}{r}87 \% \\
(-5.4 \%)\end{array}$ & $\begin{array}{r}341 \% \\
(-4.9 \%)\end{array}$ & $\begin{array}{r}82 \% \\
(-8.9 \%)\end{array}$ & $\begin{array}{r}136 \% \\
(-6.7 \%)\end{array}$ & $\begin{array}{r}51 \% \\
(-4.9 \%)\end{array}$ & \\
\hline EU-3 & $\begin{array}{r}105 \% \\
(-3.4 \%)\end{array}$ & $\begin{array}{r}84 \% \\
(-3.4 \%)\end{array}$ & $\begin{array}{r}150 \% \\
(-7.1 \%)\end{array}$ & $\begin{array}{r}204 \% \\
(-7.1 \%)\end{array}$ & $\begin{array}{r}113 \% \\
(0.3 \%)\end{array}$ & $\begin{array}{r}108 \% \\
(-2.3 \%)\end{array}$ & $\begin{array}{r}42 \% \\
(-8.1 \%)\end{array}$ \\
\hline United States & $\begin{array}{r}86 \% \\
(8.0 \%)\end{array}$ & $\begin{array}{r}63 \% \\
(0.4 \%)\end{array}$ & $\begin{array}{r}174 \% \\
(-3.5 \%)\end{array}$ & $\begin{array}{r}161 \% \\
(-5.4 \%)\end{array}$ & $\begin{array}{r}112 \% \\
(6.7 \%)\end{array}$ & $\begin{array}{r}100 \% \\
(2.9 \%)\end{array}$ & $\begin{array}{r}67 \% \\
(0.4 \%)\end{array}$ \\
\hline
\end{tabular}

ASEAN-4 = Indonesia, Malaysia, Philippines, Thailand. East Asia-3 = People's Republic of China, Japan, the Republic of Korea. Central Asia = Georgia, Kazakhstan, Kyrgyz Republic. Pacific = Fiji, Papua New Guinea. SAARC = South Asian Association for Regional Cooperation; SAARC-4 = Bangladesh, India, Pakistan, Sri Lanka. AUS-NZL = Australia, New-Zealand. EU-3: Germany, France, United Kingdom.

Notes: Trade costs may be interpreted as tariff equivalents. Percentage changes in trade costs between 2004-2009 and 2010-2015 are in parentheses.

Source: ESCAP. 2017.

Figure 3: Trade Costs of Asia and Pacific Subregions with Large Developed Economies

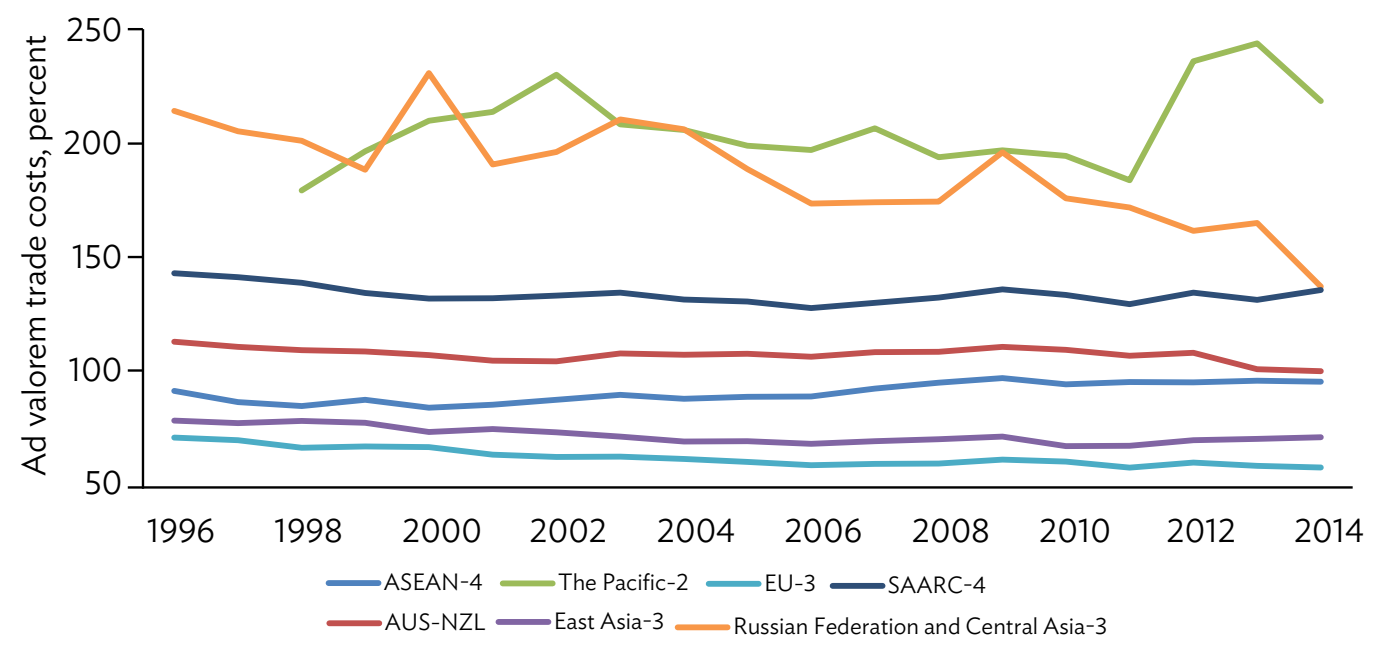

ASEAN-4 = Indonesia, Malaysia, Philippines, Thailand. AUS-NZL = Australia and New Zealand. East Asia-3 = People's Republic of China, Japan, the Republic of Korea; EU-3 = Germany, France, United Kingdom. Pacific-2 = Fiji and Papua New Guinea. Central Asia = Georgia, Kazakhstan, Kyrgyz Republic. SAARC-4 = Bangladesh, India, Pakistan, Sri Lanka.

Note: Trade costs shown are tariff equivalents, calculated as trade-weighted average trade costs of countries in each subregion with the three largest developed economies (Germany, Japan, and the United States).

Source: ESCAP. 2017. 


\section{Box 2: The World Trade Organization's Trade Facilitation Agreement}

During the 2013 Bali Ministerial Conference, World Trade Organization (WTO) member finalized negotiations on the Trade Facilitation Agreement (TFA), which came into force on 22 February 2017 upon ratification by two-thirds of members.

With the promise of alleviating bureaucratic and logistic barriers to trade, the TFA promotes customs improvements and cross-border cooperation through technical assistance and capacity building. It is the first agreement that allows WTO members to determine implementation schedules and the type of assistance needed to meet them.

Historically, complex trade processes have hampered reaching the potential of global and regional exchange. This emerged as an issue at the 1996 Singapore Ministerial Conference, which prompted further research. The consistent conclusion was that trade facilitation would lower trade costs, and formal negotiations started when the Negotiating Group on Trade Facilitation was established in 2004. The proposals moved trade facilitation toward simplified documentation and modernized customs procedures, while evidence showed that trade facilitation would allow better integration into global supply chains and expand international trade. This would help developing nations as the TFA would help increase exports from existing firms and open entry for new traders. This negotiating phase concluded in 2013. A legal review of the proposals and evidence was completed in 2014. Discussions on amendments and qualification procedures culminated in TFA ratification in 2017.

With the TFA in force, Category A provisions call for immediate implementation for developed members and within 1 year for developing country members. Meanwhile, Category B provides a transitional period, and Category $C$ requires implementation after the transitional period and upon assistance provided for capacity building. Allowances are made for developing members to maximize TFA benefits. Trade costs are estimated to drop an average 14.3\%, while global trade is expected to increase up to $\$ 1$ trillion per year.

Source: World Trade Organization. 2017.

\subsection{Implementation of Trade Facilitation and Paperless Trade Measures}

\subsubsection{Status of implementation}

In 2012, the ESCAP_-in conjunction with the Asia-Pacific Trade Facilitation Forum organized by ADB and ESCAP — conducted the first regional survey on the implementation of trade facilitation and paperless trade. A second regional survey was conducted in 2013-14. Extensive discussions at the Global Trade Facilitation Forum 2013 over the lack of reliable, detailed and regularly updated data on the implementation of trade facilitation-building on ESCAP's regional surveys - led to the first global survey, jointly by all United Nations Regional Commissions and other international organizations in 2015.

The second global survey, which has begun in early 2017, uses the final list of provisions included in the WTO TFA and the draft text of the regional UN treaty on cross-border paperless trade facilitation under negotiation at ESCAP. It covers 47 trade facilitation measures divided into seven groups-(i) general trade facilitation measures, (ii) paperless trade, (iii) cross-border paperless trade, (iv) transit facilitation, (v) trade facilitation for SMEs, (vi) agricultural trade facilitation and (vii) women in trade facilitation (as shown in Table 2). ${ }^{4}$ While general trade facilitation measures and transit facilitation measures are largely featured in the WTO TFA, most cross-border paperless trade measures are not (although they support implementation in many general trade facilitation measures).

4 The survey questionnaire and database are available at https://unnext.unescap.org/content/global-survey-trade-facilitation-and-paperless-tradeimplementation-2017 
Table 2: Grouping of Trade Facilitation Measures Included in the Questionnaire

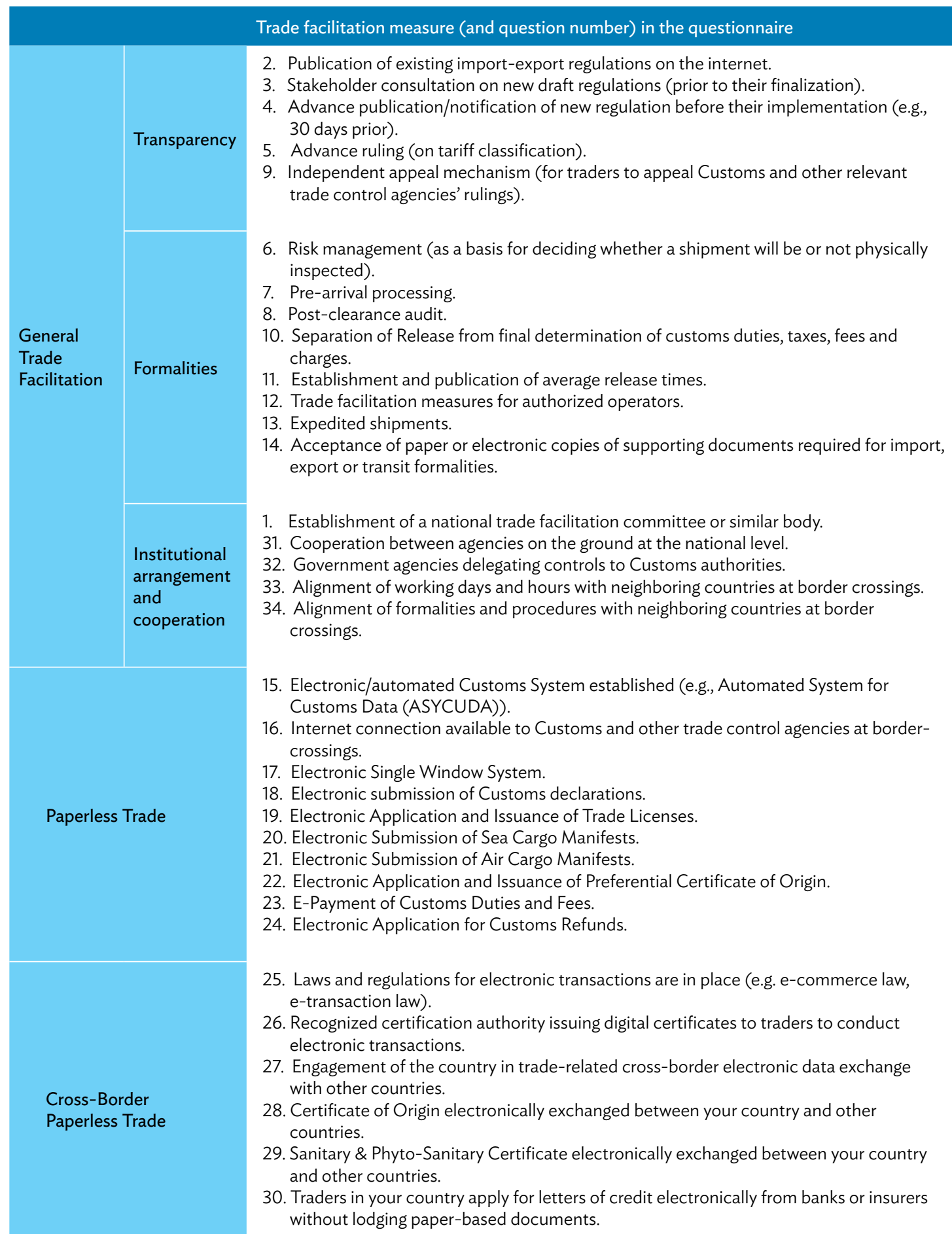

35. Transit facilitation agreement(s) with neighboring country(ies).

36. Customs Authorities limit the physical inspections of transit goods and use risk assessment.

Transit Facilitation

37. Supporting pre-arrival processing for transit facilitation.

38. Cooperation between agencies of countries involved in transit. 
Table 2: continued

Trade facilitation measure (and question number) in the questionnaire
$\begin{aligned} & \text { 39. Government has developed trade facilitation measures that ensure easy and affordable } \\ & \text { access for SMEs to trade related information. } \\ & \text { 40. Government has developed specific measures that enable SMEs to more easily benefit } \\ & \text { from the AEO scheme. }\end{aligned}$
$\begin{aligned} & \text { Trade Facilitation for } \\ & \text { Small and Medium-sized } \\ & \text { Enterprises (SMEs) }\end{aligned}$
$\begin{aligned} & \text { 41. Government has taken actions to make the single windows more easily accessible } \\ & \text { to SMEs (e.g., by providing technical consultation and training services to SMEs on } \\ & \text { registering and using the facility.) }\end{aligned}$
$\begin{aligned} & \text { 42. Government has taken actions to ensure that SMEs are well represented and made key } \\ & \text { members of National Trade Facilitation Committees. }\end{aligned}$
$\begin{aligned} & \text { 43. Testing and laboratory facilities are equipped for compliance with sanitary and } \\ & \text { phytosanitary (SPS) standards in your country. }\end{aligned}$
$\begin{aligned} & \text { 44. National standards and accreditation bodies are established for the purpose of } \\ & \text { compliance with SPS standards in your country. } \\ & \text { 45. Application, verification and issuance of SPS certificates is automated. }\end{aligned}$
$\begin{aligned} & \text { 46. The existing trade facilitation policy/strategy incorporates special consideration of } \\ & \text { women involved in trade. }\end{aligned}$
$\begin{aligned} & \text { 47. Government has introduced trade facilitation measures to benefit women involved in } \\ & \text { trade. }\end{aligned}$

Source: United Nations Regional Commissions. 2017.

For analysis and presentation of the results, each trade facilitation measure included was rated either "fully implemented," "partially implemented," "on a pilot basis," or "not implemented." A score (weight) of 3 , 2,1 , or 0 was assigned to each implementation stage to calculate scores for individual measures across countries, regions, or categories.

Implementation levels of 44 countries in Asia and the Pacific were calculated based on 31 trade facilitation and paperless trade measures (Figure 4). ${ }^{5}$ The regional average implementation of this comprehensive set of trade facilitation measures was $50.4 \%$, though results vary widely by country. Australia, the People's Republic of China, Japan, the Republic of Korea, and Singapore have implementation rates over $80 \%$, while several Pacific countries barely reach 15\%.

Figure 5 presents the rate of implementation on trade facilitation measures by subregion and groups of countries with special needs-landlocked developing countries, least developed countries, and small island developing states - as well as the average implementation rate of each group (indicated by the red bars). After Australia and New Zealand, East Asia has the highest average rate (73.7\%), followed by Southeast Asia and Timor-Leste (60.1\%), the Russian Federation and Central Asia (51.8\%), and South Asia and Turkey (46.5\%). The Pacific lagged at 28.2\%.

Implementation varies widely within each subregional group. In Southeast Asia, all Association of Southeast Asian Nations (ASEAN) countries have well-implemented trade facilitation measures. In contrast, Timor-Leste only recently began to actively engage in international trade. Differences in trade facilitation implementation are smallest in the Pacific, possibly due to economic cooperation initiatives on trade facilitation - but arguably more likely because they all face relatively similar implementation constraints.

5 Note: Among 47 trade facilitation measures surveyed, three measures including 20. Electronic Submission of Sea Cargo Manifests, 33. Alignment of working days and hours with neighboring countries at border crossings, and 34. Alignment of formalities and procedures with neighboring countries at border crossings are excluded for calculating the overall score as they are not relevant to all countries surveyed. Similarly, four transit facilitation measures are also excluded. The remaining three groups of measures related to SMEs, agricultural trade facilitation and women in trade facilitation (the trade facilitation measures 39 through 47) are excluded for calculating the overall score due to the incompleteness of dataset. 
Figure 4: Overall Implementation of Trade Facilitation Measures in 44 Asia and Pacific Countries

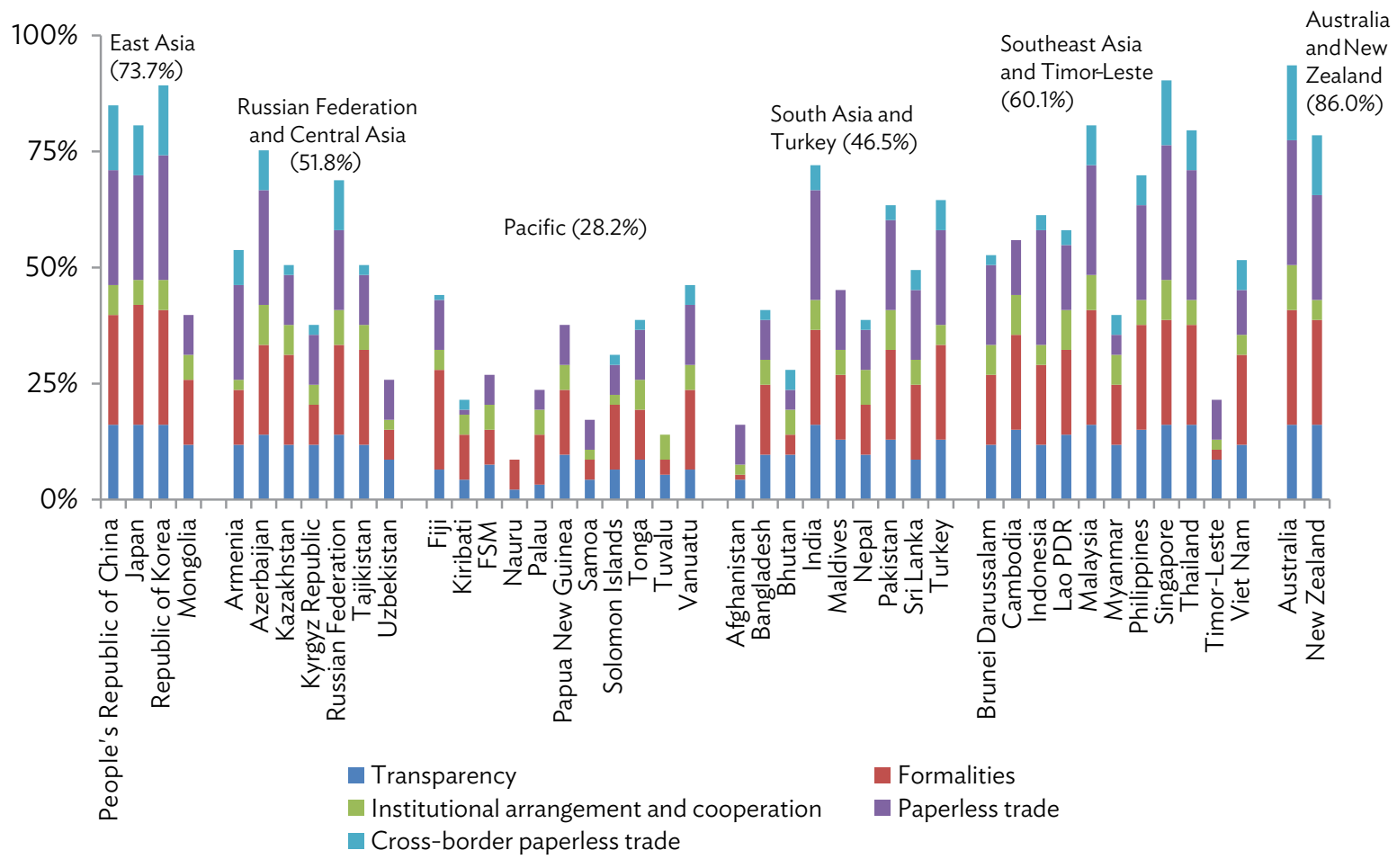

Lao PDR = Lao People's Democratic Republic, FSM = Federated States of Micronesia.

Source: United Nations Regional Commissions. 2017.

Figure 5: Trade Facilitation Implementation across Asia and Pacific Subregions and Countries with Special Needs

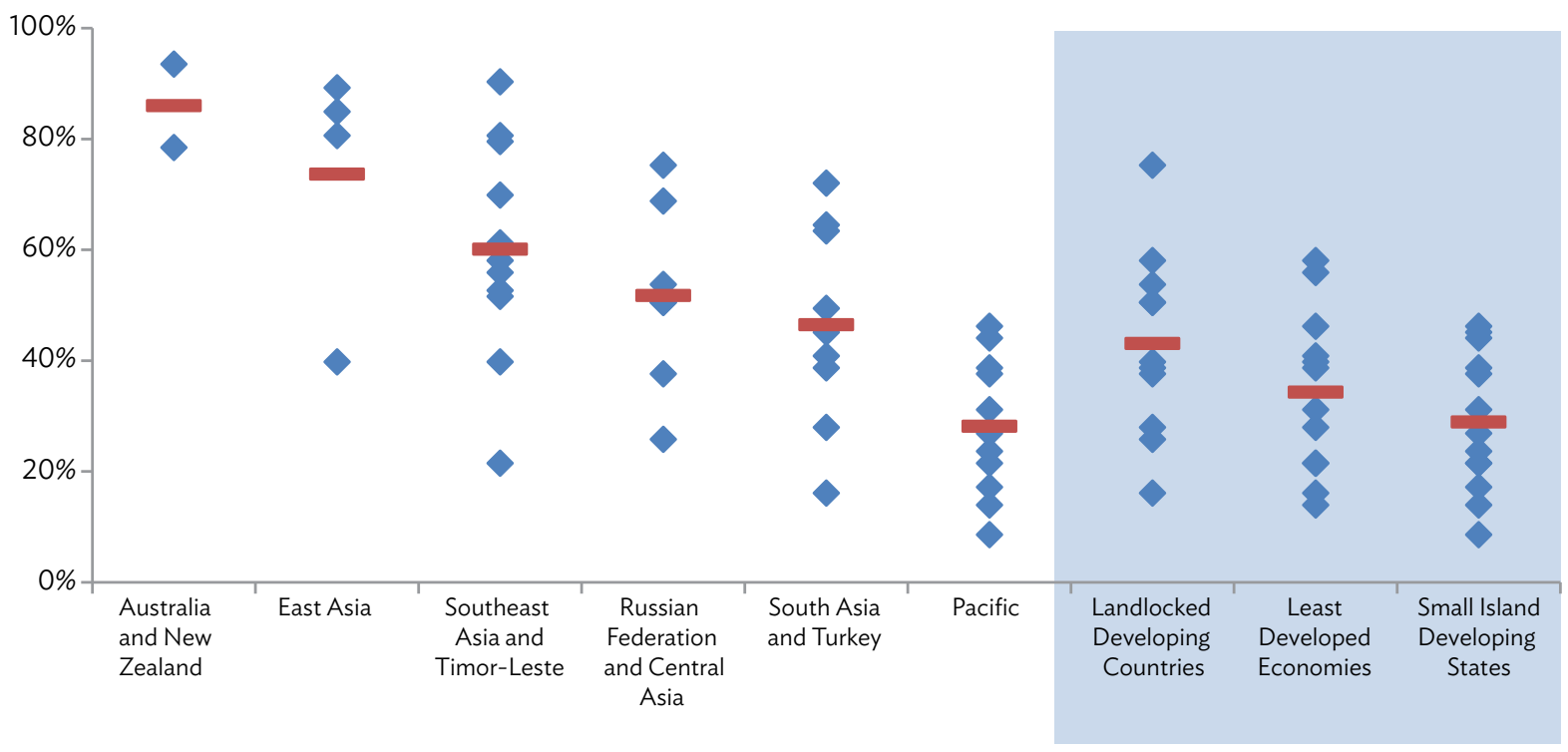

Note: Blue diamonds represent country scores; red lines are group averages.

Source: United Nations Regional Commissions. 2017. 
Countries with special needs face particular challenges in implementing trade facilitation measures-in particular paperless trade and cross-border paperless trade. Trade facilitation implementation is higher among landlocked developing countries as a group on average than among least developed countries or small island developing states. This is encouraging given the importance of trade facilitation for these economies - and the strong support of development partners in supporting trade and transport facilitation in landlocked developing countries (and in the context of the Vienna Programme of Action). ${ }^{6}$

Figure 6 shows that "transparency" measures have been the best implemented (regional average implementation at 68.5\%), followed by "formalities" measures (60\%). Measures aimed at reducing or speeding up have also been given serious attention in many economies of the region, with the regional average implementation rate exceeding 50\% in that category. Regional average implementation also reaches over $50 \%$ for measures related to "institutional arrangements and interagency cooperation" and "transit".

The regional average level of implementation of "paperless trade" measures also stands close to $50 \%$. While many economies have developed legal frameworks to enable paperless trade, implementation of "cross-border paperless trade" has yet to begin in many developing countries, with the average rate of implementation at $23 \%$.

To better reflect trade facilitation in the context of the SDGs, three groups of trade facilitation measurestrade facilitation for SMEs, trade facilitation for agricultural trade, and women in trade facilitation-were added to the survey in 2017. Figure 6 shows that, according to the data from 25 countries, agricultural trade facilitation has been generally well implemented. However, very few countries have customized trade facilitation measures to support SMEs and women, as reflected by the low average implementation rates at $39 \%$ and $23 \%$, respectively.

\section{Figure 6: Implementation of Different Groups of Trade Facilitation Measures}

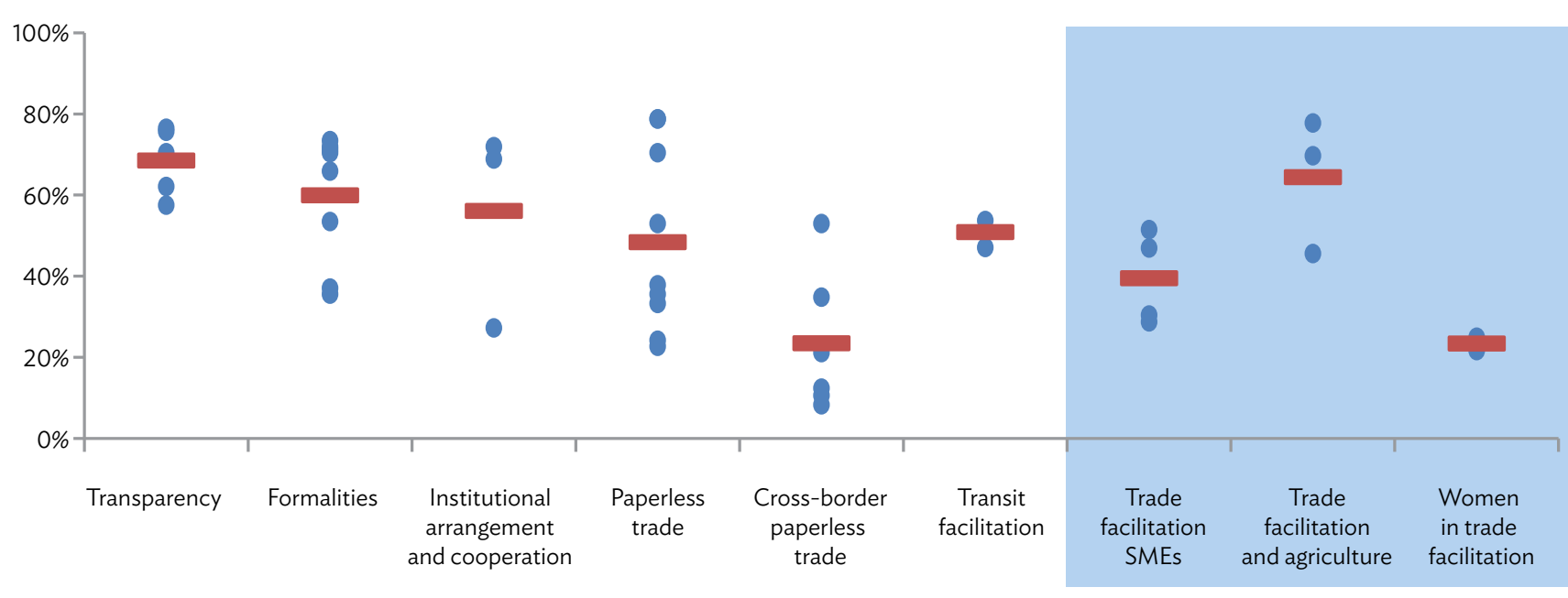

SMEs = small and medium-sized enterprises.

Note: Blue circles represent country scores; red lines are group averages.

Source: United Nations Regional Commissions. 2017.

Table 3 shows the most and least implemented areas of trade facilitation within each category of trade facilitation measures. Stakeholder consultation on new draft regulations (prior to their finalization) is the most implemented transparency measure in the region, as more than $95 \%$ of the 44 economies have either fully or partially implemented it. The least implemented transparency measures are advance ruling (on tariff classification). Still, it has been already either fully or partially implemented by almost $70 \%$ of the countries (or 30 countries) in the region.

6 See http://unohrlls.org/about-Ildcs/programme-of-action/for more information. 
Table 3: Most and Least Implemented Measures in Asia and the Pacific

\begin{tabular}{|c|c|c|}
\hline Category & Most Implemented & Least Implemented \\
\hline Transparency & $\begin{array}{l}\text { Stakeholders' consultation on new draft } \\
\text { regulations (prior to their finalization) }\end{array}$ & Advance ruling (on tariff classification) \\
\hline Formalities & Risk management & $\begin{array}{l}\text { Trade facilitation measures for } \\
\text { authorized operators }\end{array}$ \\
\hline $\begin{array}{l}\text { Institutional arrangement and } \\
\text { cooperation }\end{array}$ & $\begin{array}{l}\text { National legislative framework and } \\
\text { institutional arrangement are available } \\
\text { to ensure border agencies to cooperate } \\
\text { with each other }\end{array}$ & $\begin{array}{l}\text { Government agencies delegating } \\
\text { controls to Customs authorities }\end{array}$ \\
\hline \multirow[t]{2}{*}{ Paperless trade facilitation } & $\begin{array}{l}\text { Internet connection available to } \\
\text { Customs and other trade control } \\
\text { agencies at border-crossings }\end{array}$ & \multirow[t]{2}{*}{$\begin{array}{l}\text { Electronic Application for Customs } \\
\text { Refunds }\end{array}$} \\
\hline & Electronic/automated Customs System & \\
\hline Cross-border paperless trade & $\begin{array}{l}\text { Laws and regulations for electronic } \\
\text { transactions }\end{array}$ & $\begin{array}{l}\text { Traders in your country apply for letters } \\
\text { of credit electronically from banks or } \\
\text { insurers without lodging paper-based } \\
\text { documents }\end{array}$ \\
\hline Transit & $\begin{array}{l}\text { Transit facilitation agreement(s) with } \\
\text { neighbouring country(ies) }\end{array}$ & $\begin{array}{l}\text { Supporting pre-arrival processing for } \\
\text { transit facilitation }\end{array}$ \\
\hline Trade facilitation and SMEs & $\begin{array}{l}\text { Government has developed trade } \\
\text { facilitation measures that ensure easy } \\
\text { and affordable access for SMEs to trade } \\
\text { related information }\end{array}$ & $\begin{array}{l}\text { Government has developed specific } \\
\text { measures that enable small and } \\
\text { medium enterprises to more easily } \\
\text { benefit from the authorized economic } \\
\text { operator scheme }\end{array}$ \\
\hline Trade facilitation and agriculture trade & $\begin{array}{l}\text { Testing and laboratory facilities are } \\
\text { equipped for compliance with sanitary } \\
\text { and phytosanitary standards in your } \\
\text { country }\end{array}$ & $\begin{array}{l}\text { Application, verification and issuance of } \\
\text { sanitary and phytosanitary certificates } \\
\text { is automated }\end{array}$ \\
\hline Women in trade facilitation & $\begin{array}{l}\text { Government has introduced trade } \\
\text { facilitation measures to benefit women } \\
\text { involved in trade }\end{array}$ & $\begin{array}{l}\text { The existing trade facilitation } \\
\text { policy/strategy incorporates special } \\
\text { consideration of women involved in } \\
\text { trade }\end{array}$ \\
\hline
\end{tabular}

SMEs = small and medium-sized enterprises.

Source: United Nations Regional Commissions. 2017.

Risk management, the most implemented among the formalities measures, has been implemented by 41 countries, or $93 \%$ of the Asia and Pacific countries surveyed, although in some cases only on a pilot basis. Two measures in this group particularly stand out as poorly implemented. Trade facilitation measures for authorized operators has been initiated by slightly more than $50 \%$ of the countries. Although not shown in the table, a majority of countries have not initiated establishment and publication of average release times, with only 20 countries considered to have partially or fully implemented this measure.

Among institutional and cooperation measures, National legislative framework and institutional arrangement are available to ensure border agencies to cooperate with each other and committee have already been quite extensively implemented in the region and most subregions. In contrast, implementation levels of mechanisms enabling government agencies to delegate controls to customs authorities remain well under 30\% in Asia and the Pacific. This is particularly the case in East Asia, the Russian Federation, and Central Asia, and South Asia and Turkey where the implementation is below 20\%.

The most fully implemented among three measures considered in this group is establishment of National Trade Facilitation Committee. Establishment of such a committee is mandatory for all countries intent on ratifying the WTO TFA.? About $80 \%$ of the countries have already established the body, although it often remains unclear whether that body is fully operational or has the authority and membership necessary to support effective trade facilitation reforms.

7 See Article 23.2 of the WTO TFA. 
Among nine of the trade facilitation measures categorized as "paperless trade" measures, Internet connection available to customs and other trade control agencies at border-crossings, availability of electronic/ automated customs system, along with electronic submission of customs declarations, are among the most implemented measures of all trade facilitation measures included in the survey. In contrast, regional implementation of almost all other measures, including electronic application for customs refunds and electronic application and issuance of preferential certificates of origin are well below the overall regional implementation average. The implementation levels of "paperless trade" measures in Southeast Asia and Timor-Leste, and East Asia exceed those in the other subregions, especially for electronic single window system, electronic application and issuance of import and export permit and electronic submission of air cargo manifests (particularly in East Asia's case).

With respect to the group of "cross-border paperless trade" measures, more than $70 \%$ of the countries surveyed in Asia and the Pacific have at least partially developed the legal and regulatory frameworks needed to support electronic transactions. But these frameworks remain incomplete and may not readily support the legal recognition of electronic data or documents received from stakeholders in other countries. In part because of the lack of institutional and legal frameworks to support cross-border paperless trade, engagement in trade-related cross-border electronic data exchange has remained limited, typically conducted on a limited basis with a few specific trade partners, and often only on a pilot basis. Indeed, electronic exchange of certificates of origin and electronic exchange of sanitary and phytosanitary certificates have been implemented on a limited basis by less than $20 \%$ of the economies of the region. Similarly, in all but one Asia and Pacific country in the survey, it is not yet feasible for traders to apply for letters of credit electronically from banks or insurers without lodging paper-based documents.

\subsubsection{Implementation progress from 2015 to 2017}

There has been substantial progress in implementing trade facilatation during 2015-2017 (Figure 7). The overall average implementation rate in the region increased from $46.5 \%$ in 2015 to $50 \%$ in 2017. Figure 7 also shows progress of implementation in different subregions, landlocked developing countries, least developed countries, and Pacific island countries. The Russian Federation and Central Asia made the most progress, with the implementation rate up from 41.6\% in 2015 to $51.8 \%$ in 2017. As most countries in this group are also landlocked developing countries, these countries in Asia and the Pacific as a group enhanced implementation by $7.9 \%$ from 2015 to 2017. In contrast, the Pacific did not witness substantial improvement: implementation increased by 3.2\% from 24.9\% in 2015 to 28.2\% in 2017.

Figure 7: Trade Facilitation Implementation in 2015 and 2017

Implementation in sub-regions and countries with special needs

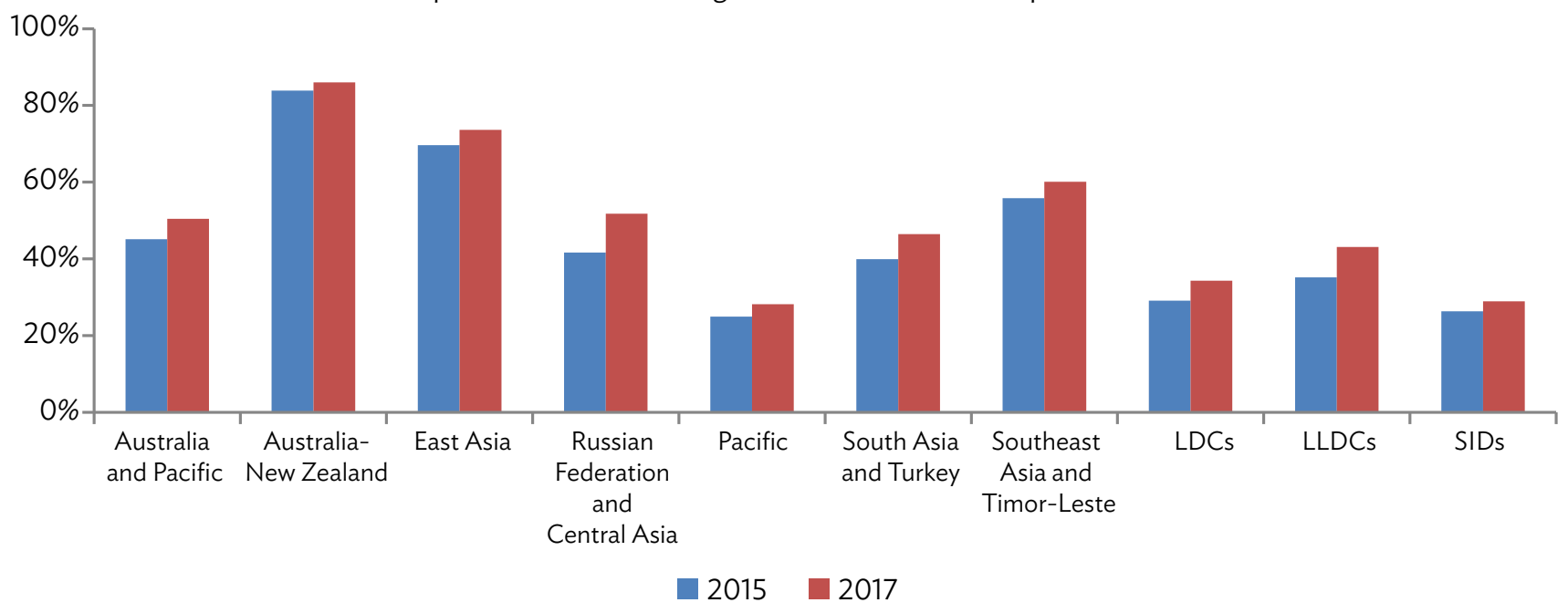

LDCs = least developed countries, LLDCs = landlocked developing countries, SIDs = small island developing countries. Source: United Nations Regional Commissions. 2017. 
Figure 8 shows that countries in Asia and the Pacific made the most progress in implementing trade facilitation measures by the WTO TFA, namely, transparency, formalities, institutional arrangement and cooperation during 2015-2017, with implementation rates from 61.8\% to 68.5\% for transparency measures, from $53.1 \%$ to $59.8 \%$ for formalities measures, and from $48.7 \%$ to $56.1 \%$ for institutional arrangement and cooperation measures. Implementation of paperless trade increased from $44.5 \%$ to $48.2 \%$ and crossborder paperless from $19.6 \%$ to $23.4 \%$.

\section{Figure 8: Implementation of Different Groups of Trade Facilitation Measures in 2015 and 2017}

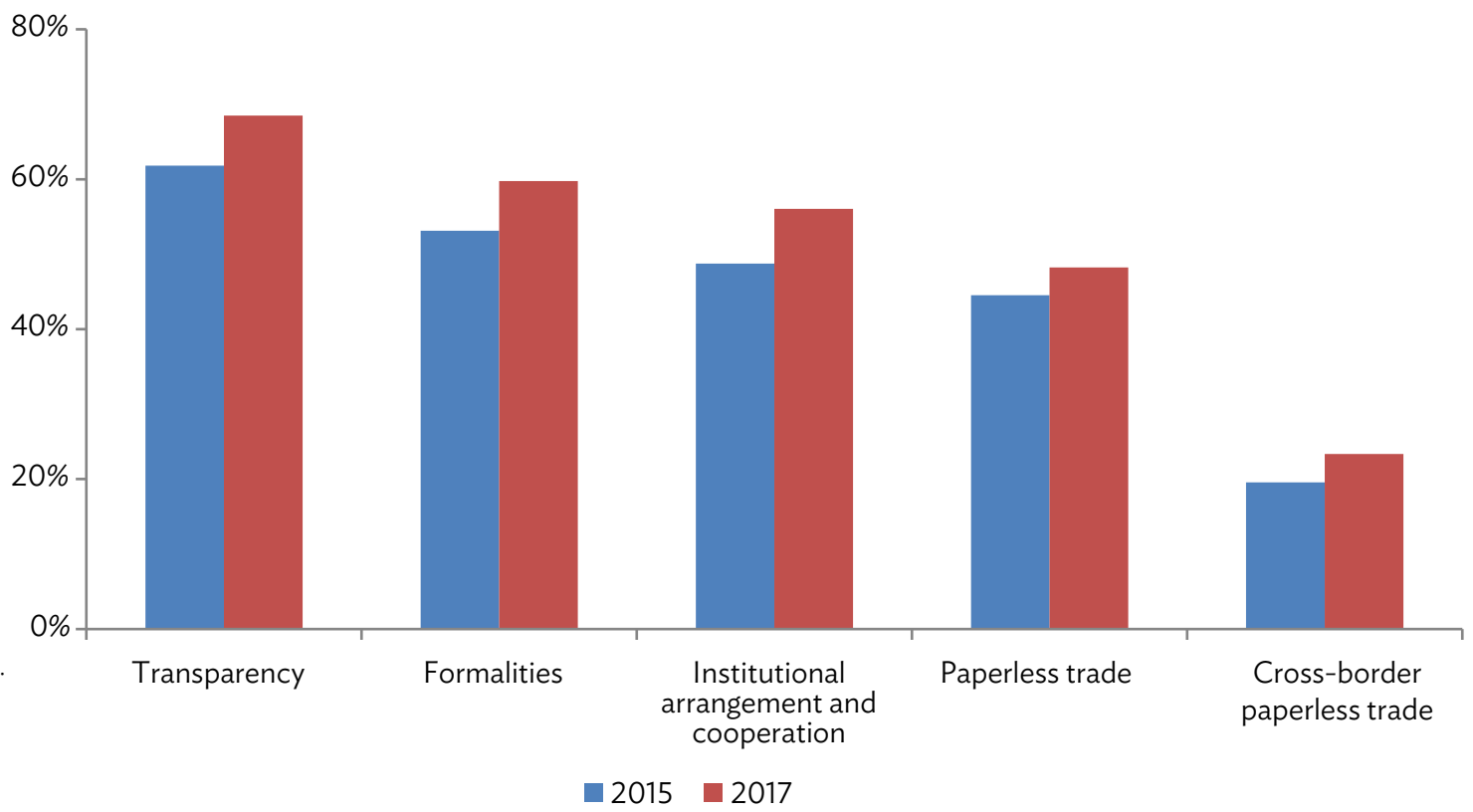

Source: United Nations Regional Commissions. 2017.

\section{Box 3: The Economic and Social Commission for Asia and the Pacific Framework Agreement on Facilitation of Cross-Border Paperless Trade}

In May 2016, after 4 years of negotiations, the Framework Agreement on Facilitation of Cross-Border Paperless Trade in Asia and the Pacific ${ }^{1}$ was adopted to facilitate implementation of such trade among willing Economic and Social Commission for Asia and the Pacific (ESCAP) members by providing a dedicated intergovernmental framework to develop legal and technical solutions.

This agreement is open for signature by ESCAP members until 30 September 2017, and will enter into force after five member states have ratified it. Entirely dedicated to facilitation of cross-border paperless trade, the agreement complements the World Trade Organization Trade Facilitation Agreement (WTO TFA), which focuses on conventional trade facilitation measures, but does not specifically features paperless trade. Indeed, implementing the Framework Agreement is expected to help ESCAP members meet the singlewindow requirements of the WTO TFA.

Benefits from the Framework Agreement are numerous, especially for small and medium-sized enterprises. First, it is expected to allow substantial reduction of paperwork thanks to the electronic exchange of data and documents, leading to communication cost reduction and time saving. Secondly, it should give SMEs from states that will ratify the agreement access to a wider market. Third, systems interoperability and norms harmonization are expected, greatly procedures.

1 Full text available here: https://treaties.un.org/doc/Treaties/2016/05/20160519\%2012-16\%20PM/Ch_X-20.pdf Source: ESCAP. 2016. http://www.unescap.org/resources/framework-agreement-facilitation-cross-border-paperless-trade-asia-andpacific (accessed 8 August 2017). 


\subsection{Subregional Cooperation Initiatives and Trade Facilitation in Asia and the Pacific}

Regional cooperation and integration $(\mathrm{RCl})$ is a strategy pursued to attain national development goals by strengthening collaboration among governments to resolve development challenges needing regional solutions. Across the subregions of Asia and the Pacific, RCI has helped advance economic development in the areas of trade and investment, infrastructure, finance, and regional public goods. Through $\mathrm{RCl}$, trade facilitation measures have effectively reduced processing time, trade costs, and travel time, not to mention other benefits such as increased labor mobility and more jobs. Although progress has been made, countries and subregions are at varied stages of development. The discussion below gives a snapshot of the progress of trade facilitation within subregions.

\subsubsection{Central Asia Regional Economic Cooperation Program}

\section{Overview}

Established in 2001, the Central Asia Regional Economic Cooperation (CAREC) program covers 11 countries-Afghanistan, Azerbaijan, the PRC, Georgia, Mongolia, Pakistan, Kazakhstan, the Kyrgyz Republic, Tajikistan, Turkmenistan, and Uzbekistan. The program focuses on regional infrastructure development and trade issues prioritizing energy, transport, trade facilitation, and trade policy.

At the heart of CAREC is an institutional framework that guides and strengthens initiatives from planning to implementation. The annual ministerial-level conference is CAREC's policy-making body, providing guidance on the program's overall direction. The Senior Officials' Meeting, ${ }^{8}$ sector coordinating committees for transport, energy, trade policy, and trade facilitation, ${ }^{9}$ and national focal points provide support. ${ }^{10}$

Despite economic recovery in some Central Asia countries, overall economic performance has been weak. Output growth in Central Asia fell to 2.1\% in 2016 from 3.1\% in 2015 as low oil prices, recession in the Russian Federation, and weak export demand continued to constrain growth.

New growth opportunities include economic corridor development-particularly the Almaty-Bishkek corridor between Kazakhstan and the Kyrgyz Republic. Still in its early phase, the corridor is "instrumental in promoting the regional cooperation agenda" by linking markets, ideas and people (CAREC). Other initiatives include the PRC's Belt and Road, the US-favored New Silk Road, the Eurasia Initiative promoted by the Republic of Korea, and the Partnership for Quality Infrastructure initiative sponsored by Japan. The entry of Kazakhstan and the Kyrgyz Republic into the Eurasian Economic Union is also expected to lower internal trade and investment barriers. The establishment of the Asian Infrastructure Investment Bank and New Development Bank expand multilateral development financing in the region.

While these developments are important, CAREC needs to adapt quickly to a "new normal" of more moderate capital inflows, subdued yet stable oil prices, and lower purchasing power of remittances. This is crucial if members are to capitalize on changing patterns of trade, particularly the "shift of resources from production that is not internationally traded to production that competes in international markets", the increasing tradability of services across borders and reorientation of trade toward Asia (World Bank 2017).

8 Coordinates cross-sectoral issues, prepares for ministerial conferences, and ensures implementation of policy decisions made at ministerial meetings.

9 Coordinates respective sectoral issues, strategy articulation, and program development and implementation.

10 The focal points ensure coordination among government agencies and other parties concerned. 


\section{Figure 9: The Central Asia Regional Economic Cooperation Corridors}

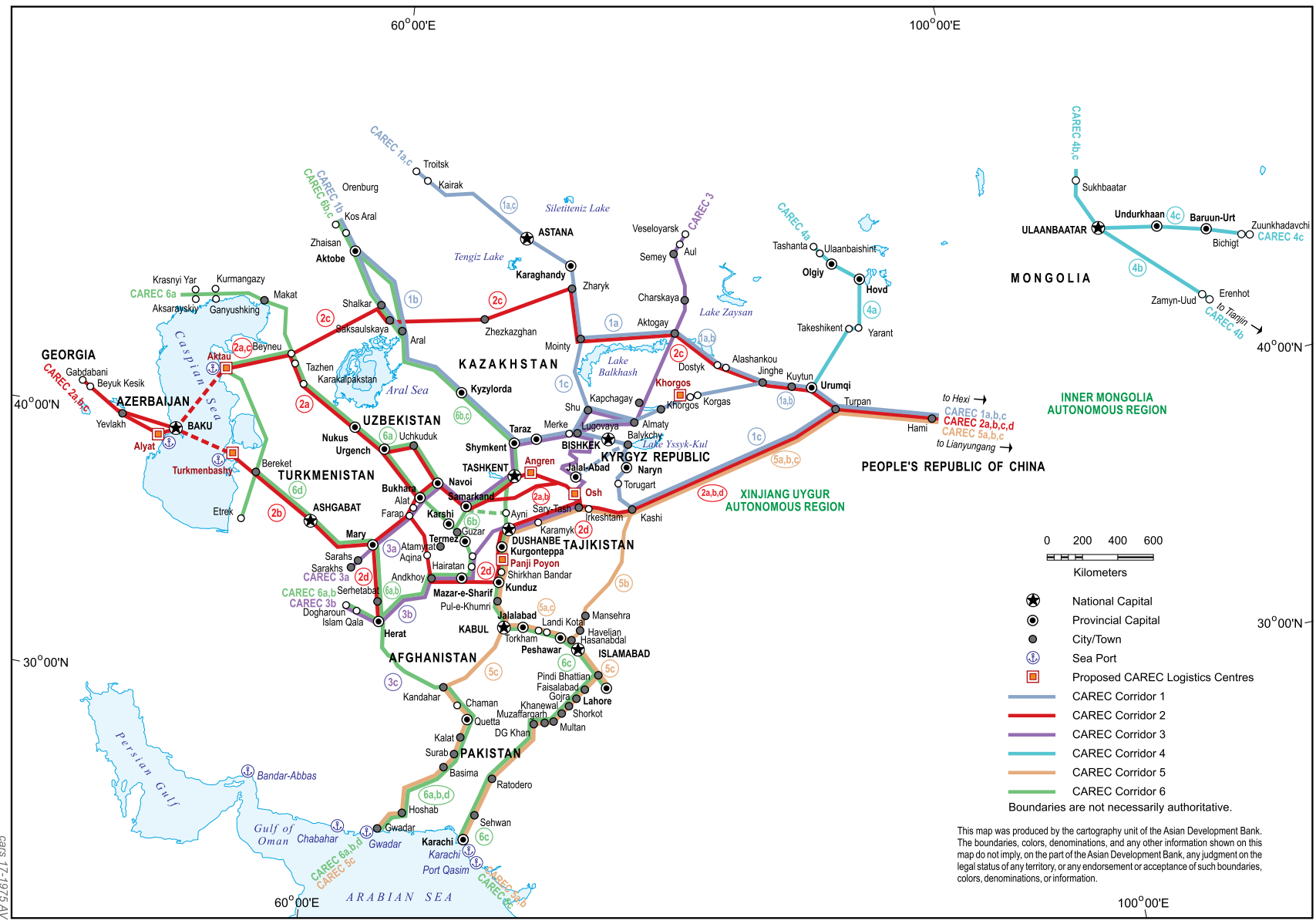

Source: Asian Development Bank.

\section{Trade facilitation in Central Asia Regional Economic Cooperation}

Trade facilitation is central to the CAREC Program." Guided by the Transport and Trade Facilitation Strategy, it aims to (i) reduce time, costs, and uncertainty in trade transactions; (ii) encourage free movement of people and goods; and (iii) enhance legal transparency. Trade facilitation has two components, ${ }^{12}$ customs cooperation on reforms and modernization, and integrated trade facilitation by establishing a regional mechanism. The trade facilitation program is coordinated through the Customs Cooperation Committee and the CAREC Federation of Carrier and Forwarder Associations. ADB assistance covers regional sanitary and phytosanitary (SPS) cooperation and border services projects in the Kyrgyz Republic, Mongolia, Pakistan, and Tajikistan.

CAREC plans six multimodal transport corridors in the region (Figure 9). By 2015, corridor implementation included the development of two ports, two logistics centers, three border crossings, and six civil aviation centers. CAREC projects contributed to building or improving 809 kilometers of expressways or national highways, 93\% of the target under the Transport and Trade Facilitation Strategy 2020. In 2015, CAREC projects covered road safety, road asset management, transport facilitation, and railway improvement.

11 As of September 2016, ADB's cumulative investments under CAREC totaled $\$ 28.9$ billion (ADB 2016; CAREC Mid-Term Report). Of the total, this figure, $\$ 22.6$ billion (78\%) was in transport, $\$ 5.7$ billion (20\%) in energy, and $\$ 0.6$ billion (2\%) in trade facilitation. ADB's share of the total was $\$ 10.1$ billion (35\%). In addition, CAREC has financed a total of $\$ 466$ million in technical assistance, of which ADB's share was $\$ 152$ million (33\%).CAREC, 2016 a.

12 The first Transport and Trade Facilitation Strategy has three components: customs reform and modernization, integrated trade facilitation, and developing efficient regional logistics. 
Trade facilitation is having a positive effect. ADB estimates the average time needed to clear a bordercrossing along CAREC transport corridors-by rail and road - was reduced by an hour in 2015 from 2014 (ADB 2016). Travel time by rail dropped by 5.2 hours, while average train speed increased $20 \%$. Crossborder clearance time by road declined $6.1 \%$ in 2015. Similarly, costs have declined-average border costs fell to $\$ 161$ in 2015 from $\$ 172$ in 2014 (road transport costs declined from \$177 to \$149). Intraregional trade volume grew 49\% from 2005 to 2013, exceeding the planned 25\% target (ADB and CAREC 2014). And road transport costs fell by $9.3 \%$ in 2015, mostly due to progress along the Trans-Mongolian Corridor (CAREC 2016b) (Table 4).

\subsubsection{Greater Mekong Subregion Program}

\section{Overview}

The Greater Mekong Subregion (GMS) Program was established in 1992 with Cambodia, the PRC (Yunnan Province and Guangxi Zhuang Autonomous Region), the Lao People's Democratic Republic (Lao PDR), Myanmar, Thailand, and Viet Nam as members (Figure 10).

The subregion's aggregate GDP expanded from $\$ 796$ billion in 2010 to $\$ 1.2$ trillion in 2015. Robust GDP per capita growth lifted incomes across the GMS, led by Guangxi and Yunnan provinces in the PRC. Poverty incidence declined in all GMS economies from the early to mid-1990s to the early 2000s.

Having started earlier than other subregional programs, GMS members are more integrated. Intra-GMS trade shares increased from 2\% in 1992 (\$5 billion) to 9.3\% in 2015 ( $\$ 444$ billion). Aggregate intra-GMS foreign direct investment increased from $\$ 8.3$ billion in 2001-2006 to $\$ 29.2$ billion in 2010-2015. Physical connectivity among members also improved. In 2015, the PRC's liner shipping bilateral connectivity index was highest with Viet Nam (0.59) and Thailand (0.58). Viet Nam's connectivity with Cambodia (0.29) and Myanmar (0.22) was more modest.

GMS uses a three-pronged strategy to enhance cooperation and integration: (i) increasing connectivity through infrastructure and economic corridors; (ii) improving competitiveness through efficient facilitation of cross-border movement and market integration; and (iii) building a sense of community through projects and programs. GMS employs a 10-year Strategic Framework to guide the program. The Strategic Framework covering 2012-2022 "expands the GMS Program from the conventional infrastructure to multi-sector investments designed to foster economic corridor development" (ADB 2013).

\section{Trade facilitation in the Greater Mekong Subregion}

A Cross-Border Transport Facilitation Agreement uses a single legal instrument for "key nonphysical measures for efficient cross-border land transport" (ADB 2011) to further increase and facilitate traffic and to promote transport and trade facilitation. In addition, a Transport and Trade Facilitation Action Program provides advisory support and capacity building. It "supports the development of a more integrated GMS market that can serve as a vibrant subregional production base" by focusing on (i) expanding transport and traffic rights, (ii) simplifying and modernizing customs procedures and border management, (iii) supporting enhanced transport and logistics, and (iv) strengthening the capacity of SPS agencies (ADB 2015b).

The Transport and Trade Facilitation Action Program has extended the East-West Economic Corridor between GMS capitals (Bangkok, Ha Noi, Vientiane), streamlined Single-Stop Customs Inspection Mechanisms at key border crossings, and implemented bilateral traffic rights exchanges between the Cambodia, the PRC, Thailand and Viet Nam, and between Cambodia and Viet Nam. Challenges remain in strengthening the institutional framework and improving coordination among stakeholders.

Thus far, projects pursued under the GMS program have yielded positive results. At key border crossings, new infrastructure and greater border efficiency cut travel time between Bavet (Cambodia) and Moc Bai (Viet Nam) in half-from about 10 hours in 1999 to 5 hours in 2013. Cross-border trade increased from $\$ 10$ million in 1999 to \$708 million in 2013. In the Moc Bai border economic zone, 41 projects totaling $\$ 270$ million were implemented and nearly 3,000 jobs created (Table 4). 
Figure 10: The Greater Mekong Subregion Economic Corridors

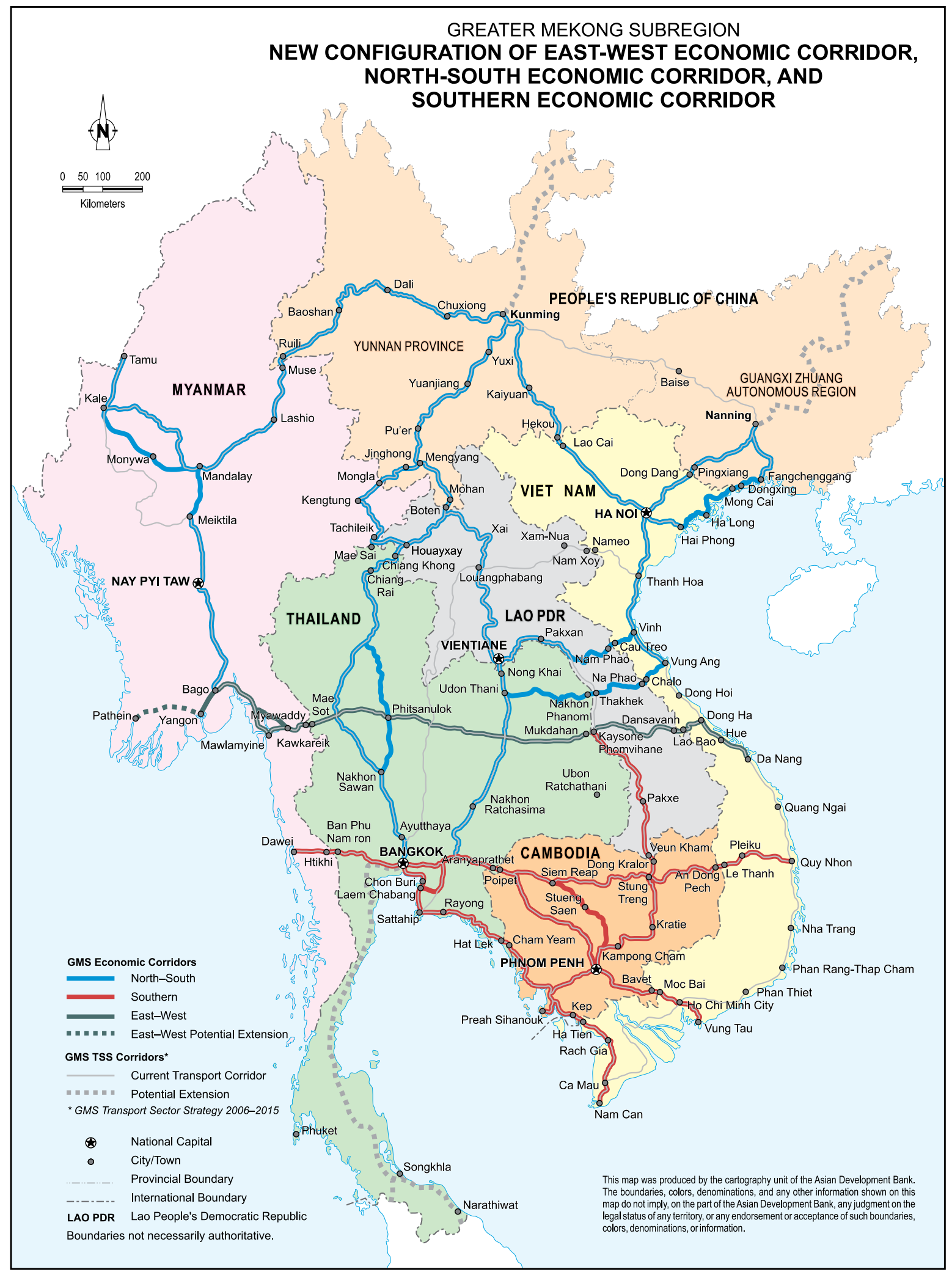

17-0264B 16GMS ABV 
Table 4: Impact of Trade Facilitation Measures at the Subregional Level

\begin{tabular}{|c|c|}
\hline Trade Facilitation Measure & Impact \\
\hline $\begin{array}{l}\text { Border-crossing improvement (Central Asia Regional } \\
\text { Economic Cooperation [CAREC]) }\end{array}$ & $\begin{array}{l}\text { Drop in average time to clear border-crossing point along } \\
\text { CAREC transport corridors in } 2015 \text { : } \\
\text { (i) by rail, down to } 5.2 \text { hours with train } \\
\text { travel speed up by } 20 \% \\
\text { (ii) by road, declined by } 6.1 \% \\
\text { Reduced costs in } 2015 \text { from } 2014 \text { : } \\
\text { (i) average border-crossing cost by } \$ 11 \\
\text { (ii) road transport cost by } \$ 23 \\
\text { Increase volume of intra-regional trade exceeding target by } \\
24 \% \text { in } 2013\end{array}$ \\
\hline Corridor improvement (CAREC) & Reduced road transport cost by $9.3 \%$ in 2015 from 2014 \\
\hline $\begin{array}{l}\text { Hardware and software improvements at key border crossing } \\
\text { points (Greater Mekong Subregion) }\end{array}$ & $\begin{array}{l}\text { Reduced travel time between Bavet, Cambodia and and Moc } \\
\text { Bai (Viet Nam) from about } 10 \text { hours in } 1999 \text { to half in } 2013 \\
\text { Increased cross-border trade from } \$ 10 \text { million in } 1999 \text { to } \$ 708 \\
\text { million in } 2013 \\
\text { Created 3,000 jobs and implemented } 41 \text { projects worth } \$ 270 \\
\text { million in Moc Bai border economic zone }\end{array}$ \\
\hline
\end{tabular}

Sources: ADB 2016, ADB and CAREC 2014, CAREC 2016a.

\subsubsection{South Asia Subregional Economic Cooperation Program}

\section{Overview}

The South Asia Subregional Economic Cooperation (SASEC) includes Bangladesh, Bhutan, India, Maldives, Nepal, Sri Lanka, and (since March 2017) Myanmar. Since 2001, SASEC has been helping members improve cross-border connectivity and increase trade using a pragmatic, results-oriented framework focused on transport, trade facilitation, and energy. Priority areas include (i) improving international corridors to expand trade and commerce; (ii) modernizing customs operations, improving border facilities, and facilitating trade through transport; and (iii) improving cross-border power transmission to boost energy security and reliability (Figure 11). Changing global economic and trade landscapes prompted SASEC to develop a new vision to meet the subregion's collective growth and development objectives.

SASEC was created with the understanding that regional cooperation can help address members' constraints of size, geography, and institutional capacity. SASEC economies individually lack the factors that typically drive faster integration while facing high costs to trade, inadequate infrastructuresmaller Bhutan and Nepal are also landlocked. ADB is SASEC's lead financier, provides the Secretariat, and generally acts as development partner. ADB support covers capacity building and institutional strengthening, various regional initiatives, and financing for projects and technical assistance (ADB 2016). 


\section{Figure 11: The South Asia Subregional Economic Cooperation Economic Corridors}

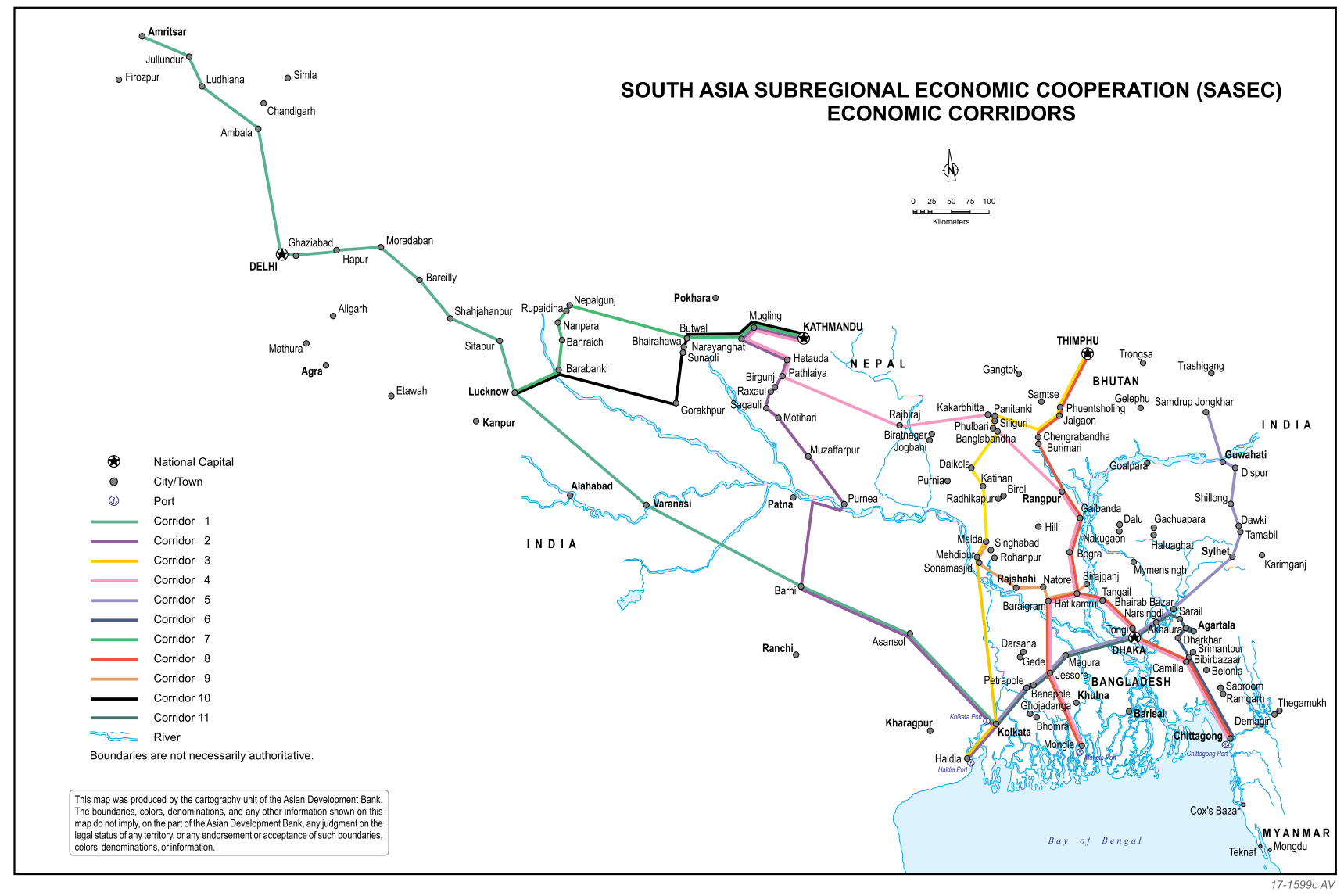

Source: Asian Development Bank.

\section{Trade facilitation in South Asia Subregional Economic Cooperation}

SASEC's Trade Facilitation Strategic Framework 2014-2018 covers national and subregional projects in five priority areas: (i) customs modernization and harmonization; (ii) standards and conformity assessments focusing on SPS measures; (iii) improving cross-border facilities, (iv) transport facilitation, and (v) institutional capacity building. It provides support to Bangladesh, Bhutan, Maldives, and Nepal for policy-based and regulatory reforms, streamlining processes and procedures, and planning institutional arrangements to establish national single windows (ADB and CAREC 2014). The Trade Facilitation Strategic Framework (through the SASEC Customs Subgroup) oversees subregional and national projects, including document exchange at major border crossings and transit process automation.

At the SASEC trade facilitation and transport working group meetings in 2010-2012, the governments of Bangladesh, Bhutan, India, and Nepal requested ADB to continue its support for SASEC trade facilitation. ADB approved SASEC Trade Facilitation Program loans and grants to Bangladesh, Bhutan, and Nepal in November 2012 to help develop modern customs administrations, streamline regulations and procedures, and provide improved services and information to traders. In addition, at the trade facilitation and transport working group meeting held in the same period, SASEC delegations agreed to expand assistance to trade facilitation further through additional technical assistance and asked ADB to explore the possibility of providing assistance to help cover specific trade facilitation needs of SASEC members. The technical assistance supports more efficient, transparent, secure, and service-oriented processing of cross-border trade across South Asia. 
Through 2025, SASEC's agenda will be framed within wider integration processes taking place in Asia. This means enhancing economic links with East Asia and Southeast Asia, among others. SASEC's connectivity agenda will be better aligned within the frameworks of SAARC and the Bengal Initiative for Multi-Sectoral Technical and Economic Cooperation (BIMSTEC) to create greater synergy with these other subregional initiatives. The SASEC Operational Plan for 2016-2025 underscores these priorities, with the current project pipeline reflecting those identified by SAARC and BIMSTEC studies-supplemented with projects that will meet the subregion's emerging needs.

To establish a trade and transport facilitation monitoring mechanism, Bangladesh, Bhutan and Nepal conducted baseline studies in 2016-2017.13 They review trade and transport procedures, report relevant indicators, analyze bottlenecks, and recommend options going forward. The mechanism baseline data will be used as the basis for benchmarking trade and transport facilitation performance over time (Box 4).

\subsubsection{The Pacific}

\section{Overview and trade facilitation}

ADB has 14 developing member countries in the Pacific. ${ }^{14}$ The countries in the region are more remote from major markets (using GDP-weighted distance) than other small island countries in the Caribbean, for example. Many Pacific island countries are also internally dispersed, with small populations spread out over vastly distant islands.

Small, remote, and dispersed populations contribute to high trade costs that undermine economic competitiveness. Summary indicators on the time and cost required for compliance with border and documentary procedures suggest that the Pacific Island trade facilitation performance is broadly comparable with countries at similar income levels. However, Figures 4 and 5 show, developing countries in the Pacific lag the rest of Asia in implementing trade facilitation reforms. Six of ADB's 14 Pacific developing member countries are full WTO members and a seventh has observer status. However, none of these countries has yet submitted a protocol of acceptance for the WTO TFA.

Improving connectivity is a key pillar of ADB's Pacific Approach 2016-2020 and ADB Country Partnership Strategies for Fiji, Papua New Guinea, and Timor-Leste. ADB has been one of the leading supporters of investments that improve transport connectivity through shipping, aviation, and road transport. ADB has also financed undersea telecommunications cables. It is currently implementing a regional technical assistance on trade and transport facilitation to identify and prioritize investments that support improved transport and trade links, both physical and soft infrastructure. The project includes creating trade forecasts, assessing transport demand and existing bottlenecks, and implementing a trade and transport monitoring mechanism in selected countries. Trade facilitation assessments are done using a participatory approach to build national capacity. Where relevant, there are also alignment with country level technical assistance programs.

Given the natural disadvantages of small and remote markets, it is essential Pacific members minimize policy-induced constraints to trade. ESCAP's analysis suggests that Pacific island countries can significantly reduce trade costs through better trade facilitation. ADB's project will help develop a richer baseline on trade facilitation performance in the Pacific and prioritize the investments that improve connectivity. Moving forward, ADB has an important role to play in helping access the financing and technical expertise needed to strengthen trade facilitation across the subregion. Given the potentially economy-wide benefits from improved trade facilitation, there may be scope for ADB to provide financing support for trade facilitation through policy-based lending operations (ADB 2017b).

13 The first set of the study reports for Bangladesh have been published and can be seen at https://www.adb.org/publications/ttfmm-baseline-studybangladesh. The other two reports, for Bhutan and Nepal, will be released in 2017.

14 The Cook Islands, the Federated States of Micronesia, Fiji, Kiribati, the Marshall Islands, Nauru, Papua New Guinea, Palau, Samoa, Solomon Islands, Timor-Leste, Tonga, Tuvalu, and Vanuatu. 


\section{Box 4: Toward a National Integrated and Sustainable Trade and Transport Facilitation Monitoring Mechanism}

Despite the efforts made by many developing countries to facilitate trade and transport, few have effective mechanisms in place to monitor the actual effectiveness of their trade and transport facilitation reforms and identify the trade and transport process and procedures that should be prioritized for simplification or streamlining. To bridge the gap, the Economic and Social Commission for Asia and the Pacific and the Asian Development Bank have jointly developed a guide on establishing a national integrated and sustainable Trade and Transport Facilitation Monitoring Mechanism to enable countries to monitor progress in trade facilitation and adapt strategies to changing national, regional and global environments.

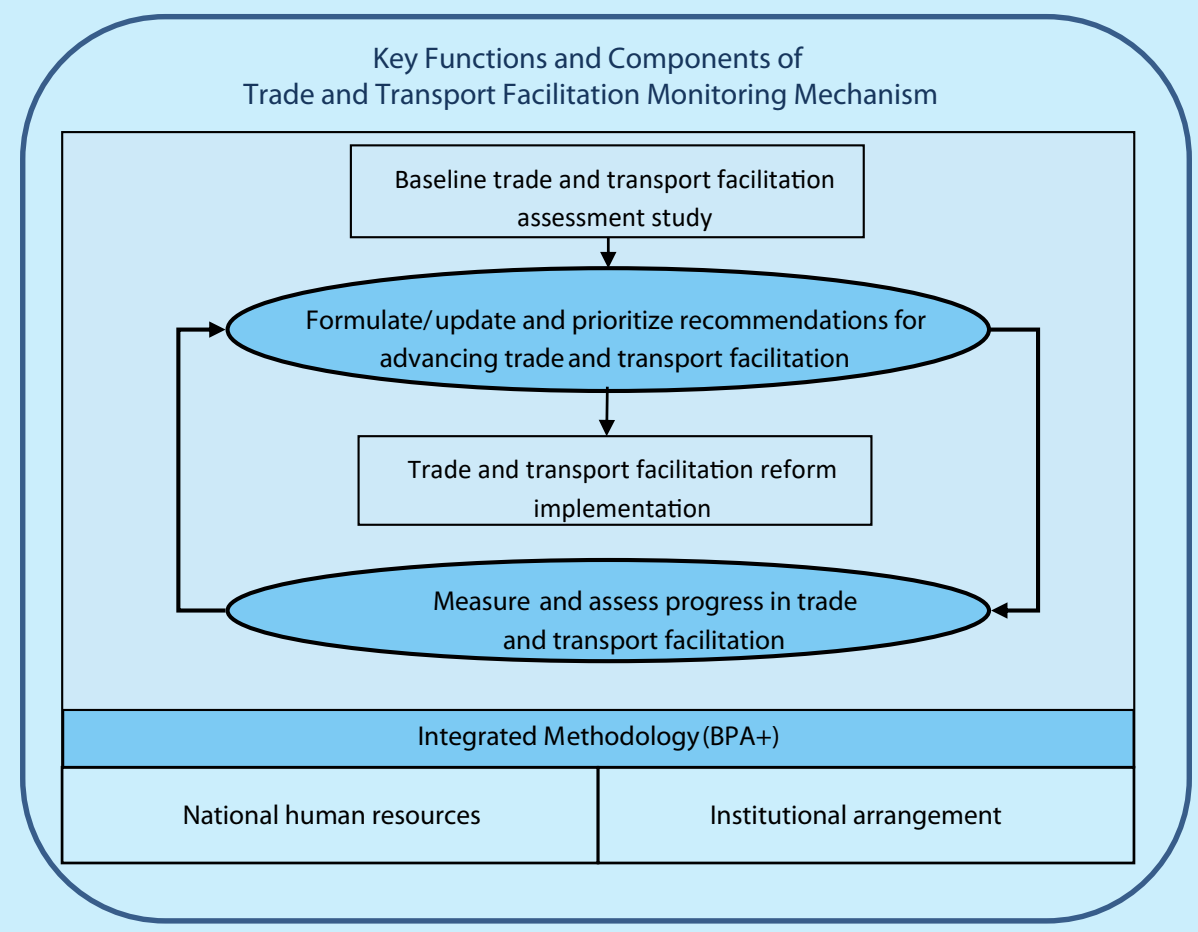

$\mathrm{BPA}+=$ Business Process Analysis Plus.

Source: ESCAP and ADB 2014

The key functions of the Trade and Transport Facilitation Monitoring Mechanism are two-fold: (i) to formulate/update and prioritize recommendations for advancing trade facilitation; and (ii) to measure and assess progress in trade facilitation. It is emphasized that mechanism should be anchored with national trade and transport facilitation committee (or an equivalent institution) and rely upon national resources to make it sustainable and affordable. Underpinning the mechanism is the methodology called Business Process Analysis Plus, which is built on the Business Process Analysis methodology, supplemented by time release studies and time-cost-distance methodologies.

The Trade and Transport Facilitation Monitoring Mechanism is being implemented in Bangladesh, Bhutan and Nepal. The baseline studies have been completed (the report for Bangladesh is available from https://www.adb.org/publications/ttfmm-baseline-study-bangladesh). The initial work of ADB and ESCAP led to the development of the United Nations Centre for Trade Facilitation and Electronic Business Recommendation 42 on Trade and Transport Facilitation Monitoring Mechanism.

Sources: ESCAP and ADB 2014, UN/CEFACT 2017. 


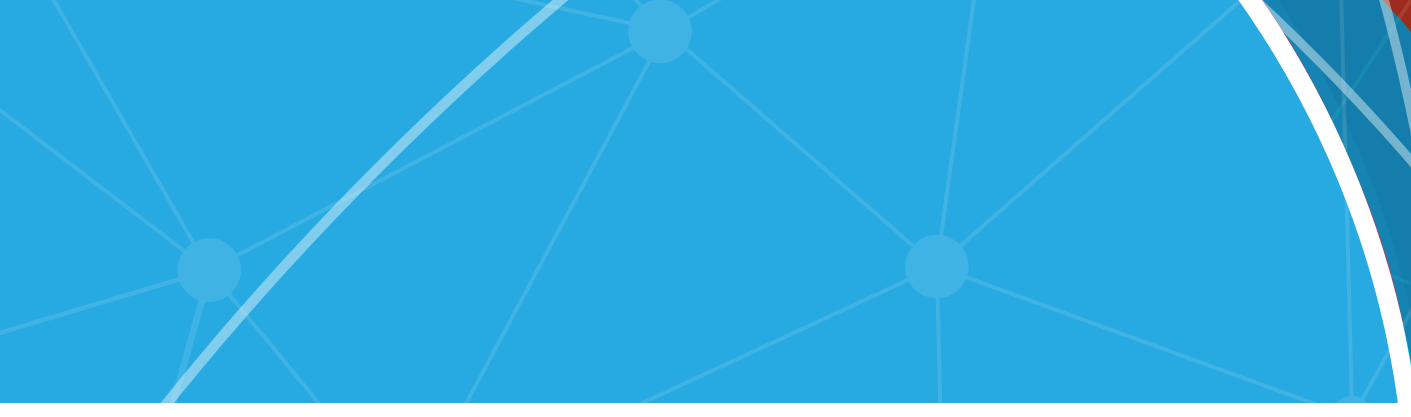

\section{ASSESSING IMPACTS OF TRADE FACILITATION}

\subsection{Trade Facilitation Impact on Trade Costs: Evidence from Asia and the Pacific*}

This section investigates the effect of trade facilitation on trade costs using regression analysis. The explanatory variables in the model include trade facilitation measures featured in the WTO TFA as well as more advanced paperless and cross-border paperless trade measures.

\subsubsection{Trade cost model and data}

Overall, or comprehensive, trade costs can be modelled as a function of natural geographic factors (distance, "landlockedness", and contiguity), cultural and historical distance (common official language, common unofficial language, former colonial relationships, and formerly same country), and the presence of regional trade agreements and liner shipping connectivity index (LSCI) (see Arvis et al. 2013). In addition to trade facilitation implementation indicators, an index of credit information quality and availability is included to capture the impact of the domestic business environment on trade costs in general as well as access to and cost of financial services, in particular. The trade cost model is specified as:

$$
\begin{aligned}
\ln \left(\tau_{\mathrm{ij}}\right)= & \beta_{0}+\beta_{1} \ln \left(\text { gtariff }_{\mathrm{ij}}\right)+\beta_{2} \ln \left(\text { dist }_{\mathrm{ij}}\right)+\beta_{3}\left(\operatorname{contig}_{\mathrm{ij}}\right)+\beta_{4}\left(\text { comlang_off }_{\mathrm{ij}}\right) \\
& +\beta_{5}\left(\text { comlang_ethno }_{\mathrm{ij}}\right)+\beta_{6}\left(\text { colony }_{\mathrm{ij}}\right)+\beta_{8}\left(\operatorname{comcol}_{\mathrm{ij}}\right)+\beta_{8}\left(\text { smctry }_{\mathrm{ij}}\right)+\beta_{8}\left(\text { rta }_{\mathrm{ij}}\right) \\
& \left.+\beta_{10} \text { (landlocked }_{\mathrm{ij}}\right)+\beta_{11} \ln \left(\operatorname{credit}_{\mathrm{i}}\right)+\beta_{12} \ln \left(\operatorname{LSCI}_{\mathrm{i}}\right)+\beta_{13} \ln \left(\mathrm{TF}_{\mathrm{i}}\right)+\mathrm{D}_{\mathrm{j}}+\varepsilon_{\mathrm{ij}}
\end{aligned}
$$

Table 5 summarizes the definition, data sources, and expected signs of all the factors included in the model. Data on trade facilitation implementation rates are calculated based on the first global survey conducted in 2015. ${ }^{15}$ Thirty-one common trade facilitation measures are included for analysis. ${ }^{16}$ Fixedeffects for partner countries (Dj) are included to account for cross-country heterogeneity as well as to increase estimation efficiency. Robust standard errors are also clustered by country pairs. The model is estimated using ordinary least squares (OLS) across a cross-section of 90 reporting countries.

\subsubsection{Regression analysis results}

Panel regression estimates of the trade cost model are shown in Table 6. The model was estimated using three different specifications of trade facilitation reform: The first model (1) is estimated using the average trade facilitation implementation rate across all 31 trade facilitation measures; model (2) features the average trade implementation rate for general trade facilitation measures (that is, measures that need to be implemented as part of WTO TFA commitments, including transparency measures, formalities measures and institutional measures) as well as the average implementation rates for paperless trade measures (i.e., measures that typically go beyond the WTO TFA commitments including paperless and cross-border paperless measures); Model (3) distinguishes between the effects of the four groups of trade facilitation measures defined in Table 5-transparency measures, formalities measures, institutional measures, and paperless and cross-border paperless trade measures.

\footnotetext{
Section 3.1 draws from the previous study of ESCAP (ESCAP 2015) and updates it using the latest available data.

15 This is to be in line with the ESCAP-World Bank trade cost database, of which the latest data were year 2015.

16 Detailed information about the 31 indicators used for calculation is shown in Table 2.
} 


\section{Table 5: Description of Variables in the Model}

\begin{tabular}{|c|c|c|c|c|}
\hline Variable & Definition & $\begin{array}{l}\text { Data } \\
\text { Treatment }\end{array}$ & Source & $\begin{array}{l}\text { Expected } \\
\text { Sign }\end{array}$ \\
\hline$\tau_{i j}$ & Comprehensive trade costs. & $\begin{array}{l}\text { Average of } \\
2013-2015\end{array}$ & $\begin{array}{l}\text { World Bank-ESCAP } \\
\text { Trade Cost Databank }\end{array}$ & $\ldots$ \\
\hline $\operatorname{gtariff}_{i j}$ & $\begin{array}{l}\text { Geometric average tariff factor }(1+\text { rate }) \text { that each } \\
\text { reporting country (i) charges to its trade partner } \\
\text { (j) and vice versa, which can be expressed by } \\
\text { gtariff }_{i j t}=\sqrt{\text { tariff }} f_{i j t} \times \text { tariff } \\
\text { ijt }\end{array}$ & $\begin{array}{l}\text { Average of } \\
2013-2015\end{array}$ & $\begin{array}{l}\text { World Integrated } \\
\text { Trade Solution }\end{array}$ & + \\
\hline dist $_{i j}$ & Geographical distance between country i and j. & $\ldots$ & CEPII & + \\
\hline contig $_{i j}$ & $\begin{array}{l}\text { Dummy variable of contiguity equal to } 1 \text { if country } i \\
\text { and } j \text { share a common border and zero otherwise. }\end{array}$ & $\ldots$ & CEPII & - \\
\hline comlang_off $_{i j}$ & $\begin{array}{l}\text { Dummy variable of common language equal to } \\
1 \text { if country } i \text { and } j \text { use the same common official } \\
\text { language and zero otherwise. }\end{array}$ & $\ldots$ & CEPII & - \\
\hline comlang_ethno $i j$ & $\begin{array}{l}\text { Dummy variable of common language equal to } 1 \text { if a } \\
\text { language is spoken by at least } 9 \% \text { of the population } \\
\text { in both countries and zero otherwise. }\end{array}$ & $\ldots$ & CEPII & - \\
\hline colony $_{i j}$ & $\begin{array}{l}\text { Dummy variable equal to } 1 \text { if country } i \text { and } j \text { were } \\
\text { ever in colonial relationship and zero otherwise. }\end{array}$ & $\ldots$ & CEPII & - \\
\hline comcol $_{i j}$ & $\begin{array}{l}\text { Dummy variable equal to } 1 \text { if country } i \text { and } j \text { had a } \\
\text { common colonizer after } 1945 \text { and zero otherwise. }\end{array}$ & $\ldots$ & CEPII & - \\
\hline smctry $_{i j}$ & $\begin{array}{l}\text { Dummy variable equal to } 1 \text { if country } i \text { and } j \text { were or } \\
\text { are the same country and zero otherwise. }\end{array}$ & $\ldots$ & CEPII & - \\
\hline$r t a_{i j}$ & $\begin{array}{l}\text { Dummy variable equal to } 1 \text { if country } i \text { and } j \text { are } \\
\text { members of the same regional trade agreement and } \\
\text { zero otherwise. }\end{array}$ & $\begin{array}{l}\text { Latest definition } \\
\text { in } 2015\end{array}$ & De Sousa, J. (2012) & - \\
\hline landlocked $_{i j}$ & $\begin{array}{l}\text { Dummy variable equal to } 1 \text { if either country i or } j \text { is } \\
\text { landlocked and zero otherwise. }\end{array}$ & $\ldots$ & CEPII & + \\
\hline credit $_{i}$ & Average access to credit index of country i.. & $\begin{array}{l}0.0001 \\
\text { replacement/ } \\
\text { average of } \\
\text { DB2014- } \\
\text { DB2016 }\end{array}$ & $\begin{array}{l}\text { Distance to frontier in } \\
\text { Doing Business }\end{array}$ & - \\
\hline$L S C I_{i}$ & $\begin{array}{l}\text { Average scores of liner shipping connectivity index } \\
\text { of country i. }\end{array}$ & $\begin{array}{l}\text { Data filling/ } \\
\text { average of } \\
2013-2015\end{array}$ & UNCTAD & - \\
\hline$T F I_{i}$ & $\begin{array}{l}\text { Percentage of TF implementation of country i, } \\
\text { modelled as: (a) overall TF;, (b) general TF + } \\
\text { paperless trade; or (ci) transparency + formalities + } \\
\text { institutional arrangements + paperless and cross- } \\
\text { border paperless trade). }\end{array}$ & $\begin{array}{l}0.0001 \\
\text { replacement } \\
\text { data in } \\
2014-2015\end{array}$ & $\begin{array}{l}\text { Global Survey on } \\
\text { Trade Facilitation } \\
\text { and Paperless Trade } \\
\text { Implementation: 2014- } \\
2015\end{array}$ & - \\
\hline
\end{tabular}

CEPII = Centre d'Études Prospectives et d'Informations Internationales, LSCI = liner shipping connectivity index of country, TFI = trade facilitation implementation, UNCTAD = United Nations Conference on Trade and Development.

Note: Where available, the average of the most recent data from 2012 onwards is used in the estimation. Data filling for LSCI is required to ensure inclusion of landlocked economies. Port countries are used as proxies for landlocked countries' portal performance. For the TF components and credit information index, zeros are replaced by 0.0001 to prevent observations being omitted from the estimation.

${ }^{1}$ Data for access to credit from the Doing Business Report is lagged one year, that is, data from the Doing Business Report 2014 are from 2013. 
Trade Facilitation and Better Connectivity for an Inclusive Asia and Pacific

Table 6: Trade Cost Model Results

\begin{tabular}{|c|c|c|c|c|c|c|}
\hline \multirow[b]{2}{*}{ Dependent variable: In_ctcij } & \multicolumn{3}{|c|}{ Beta coefficient } & \multicolumn{3}{|c|}{ Standardized beta coefficient } \\
\hline & $\begin{array}{l}\text { (1) } \\
\text { overall } \\
\text { TFI }\end{array}$ & $\begin{array}{l}\text { (2) } \\
\text { general } \\
\text { TFI }\end{array}$ & $\begin{array}{c}\text { (3) } \\
\text { TFI } \\
\text { indicators }\end{array}$ & $\begin{array}{l}\text { (1) } \\
\text { overall } \\
\text { TFI }\end{array}$ & $\begin{array}{c}\text { (2) } \\
\text { general } \\
\text { TFI }\end{array}$ & $\begin{array}{c}\text { (3) } \\
\text { TFI } \\
\text { indicators }\end{array}$ \\
\hline In_tariff & $\begin{array}{l}0.558^{* * *} \\
(6.337)\end{array}$ & $\begin{array}{l}0.552^{* * *} \\
(6.242)\end{array}$ & $\begin{array}{l}0.477^{* * *} \\
(5.280)\end{array}$ & $\begin{array}{l}0.0618^{* * *} \\
(6.337)\end{array}$ & $\begin{array}{l}0.0612^{* * *} \\
(6.242)\end{array}$ & $\begin{array}{l}0.0527^{* * *} \\
(5.280)\end{array}$ \\
\hline In_dist & $\begin{array}{l}0.193^{* * *} \\
(45.67)\end{array}$ & $\begin{array}{l}0.192^{* * *} \\
(45.34)\end{array}$ & $\begin{array}{l}0.195^{* * *} \\
(45.12)\end{array}$ & $\begin{array}{l}0.383^{* * *} \\
(45.67)\end{array}$ & $\begin{array}{l}0.380^{* * *} \\
(45.34)\end{array}$ & $\begin{array}{l}0.387^{* * *} \\
(45.12)\end{array}$ \\
\hline contig & $\begin{array}{l}-0.133^{* * *} \\
(-6.543)\end{array}$ & $\begin{array}{l}-0.135^{* * *} \\
(-6.636)\end{array}$ & $\begin{array}{l}-0.131^{* * *} \\
(-6.276)\end{array}$ & $\begin{array}{l}-0.0545^{* * *} \\
(-6.543)\end{array}$ & $\begin{array}{l}-0.0552^{* * *} \\
(-6.636)\end{array}$ & $\begin{array}{l}-0.0536^{* * *} \\
(-6.276)\end{array}$ \\
\hline comlang_off & $\begin{array}{l}-0.0463^{* * *} \\
(-3.302)\end{array}$ & $\begin{array}{l}-0.0474^{* * *} \\
(-3.353)\end{array}$ & $\begin{array}{l}-0.0445^{* * *} \\
(-3.154)\end{array}$ & $\begin{array}{l}-0.0409^{* * *} \\
(-3.302)\end{array}$ & $\begin{array}{l}-0.0418^{* * *} \\
(-3.353)\end{array}$ & $\begin{array}{l}-0.0393^{* * *} \\
(-3.154)\end{array}$ \\
\hline comlang_ethno & $\begin{array}{l}-0.00833 \\
(-0.621)\end{array}$ & $\begin{array}{l}-0.00698 \\
(-0.516)\end{array}$ & $\begin{array}{l}-0.00544 \\
(-0.403)\end{array}$ & $\begin{array}{l}-0.00754 \\
(-0.621)\end{array}$ & $\begin{array}{l}-0.00632 \\
(-0.516)\end{array}$ & $\begin{array}{l}-0.00494 \\
(-0.403)\end{array}$ \\
\hline colony & $\begin{array}{l}-0.150^{* * *} \\
(-7.254)\end{array}$ & $\begin{array}{l}-0.149^{* * *} \\
(-7.209)\end{array}$ & $\begin{array}{l}-0.153^{* * *} \\
(-7.280)\end{array}$ & $\begin{array}{l}-0.0511^{* * *} \\
(-7.254)\end{array}$ & $\begin{array}{l}-0.0508^{* * *} \\
(-7.209)\end{array}$ & $\begin{array}{l}-0.0525^{* * *} \\
(-7.280)\end{array}$ \\
\hline comcol & $\begin{array}{l}-0.0805^{* * *} \\
(-6.901)\end{array}$ & $\begin{array}{l}-0.0775^{* * *} \\
(-6.655)\end{array}$ & $\begin{array}{l}-0.0844^{* * *} \\
(-7.112)\end{array}$ & $\begin{array}{l}-0.0579^{* * *} \\
(-6.901)\end{array}$ & $\begin{array}{l}-0.0558^{* * *} \\
(-6.655)\end{array}$ & $\begin{array}{l}-0.0607^{* * *} \\
(-7.112)\end{array}$ \\
\hline smctry & $\begin{array}{l}-0.0652^{* *} \\
(-2.276)\end{array}$ & $\begin{array}{l}-0.0682^{* *} \\
(-2.387)\end{array}$ & $\begin{array}{l}-0.0646^{* *} \\
(-2.176)\end{array}$ & $\begin{array}{l}-0.0181^{* *} \\
(-2.276)\end{array}$ & $\begin{array}{l}-0.0190^{* *} \\
(-2.387)\end{array}$ & $\begin{array}{l}-0.0179^{* *} \\
(-2.176)\end{array}$ \\
\hline landlocked_ij & $\begin{array}{l}0.273^{* * *} \\
(28.35)\end{array}$ & $\begin{array}{l}0.275^{* * *} \\
(28.45)\end{array}$ & $\begin{array}{l}0.281^{* * *} \\
(28.25)\end{array}$ & $\begin{array}{l}0.313^{* * *} \\
(28.35)\end{array}$ & $\begin{array}{l}0.314^{* * *} \\
(28.45)\end{array}$ & $\begin{array}{l}0.321^{* * *} \\
(28.25)\end{array}$ \\
\hline rta & $\begin{array}{l}-0.0847^{* * *} \\
(-10.65)\end{array}$ & $\begin{array}{l}-0.0858^{* * *} \\
(-10.77)\end{array}$ & $\begin{array}{l}-0.0849^{* * *} \\
(-10.46)\end{array}$ & $\begin{array}{l}-0.0883^{* * *} \\
(-10.65)\end{array}$ & $\begin{array}{l}-0.0895^{* * *} \\
(-10.77)\end{array}$ & $\begin{array}{l}-0.0887^{* * *} \\
(-10.46)\end{array}$ \\
\hline In_credit_i & $\begin{array}{l}-0.0457^{* * *} \\
(-8.103)\end{array}$ & $\begin{array}{l}-0.0468^{* * *} \\
(-8.240)\end{array}$ & $\begin{array}{l}-0.0454^{* * *} \\
(-7.223)\end{array}$ & $\begin{array}{l}-0.0569^{* * *} \\
(-8.103)\end{array}$ & $\begin{array}{l}-0.0583^{* * *} \\
(-8.240)\end{array}$ & $\begin{array}{l}-0.0541^{* * *} \\
(-7.223)\end{array}$ \\
\hline In_Isci_i & $\begin{array}{l}-0.122^{* * *} \\
(-32.68)\end{array}$ & $\begin{array}{l}-0.121^{* * *} \\
(-32.24)\end{array}$ & $\begin{array}{l}-0.120^{* * *} \\
(-31.93)\end{array}$ & $\begin{array}{l}-0.259^{* * *} \\
(-32.68)\end{array}$ & $\begin{array}{l}-0.256^{* * *} \\
(-32.24)\end{array}$ & $\begin{array}{l}-0.256^{* * *} \\
(-31.93)\end{array}$ \\
\hline In_transparency_i & & & $\begin{array}{l}-0.0703^{* * *} \\
(-5.900)\end{array}$ & & & $\begin{array}{l}-0.0558^{* * *} \\
(-5.900)\end{array}$ \\
\hline In_formalities_i & & & $\begin{array}{l}-0.0630^{* * *} \\
(-5.347)\end{array}$ & & & $\begin{array}{l}-0.0554^{* * *} \\
(-5.347)\end{array}$ \\
\hline In_institution_i & & & $\begin{array}{l}-0.0342^{* * *} \\
(-4.560)\end{array}$ & & & $\begin{array}{l}-0.0358^{* * *} \\
(-4.560)\end{array}$ \\
\hline In_generaltf_i & & $\begin{array}{l}-0.188^{* * *} \\
(-13.50)\end{array}$ & & & $\begin{array}{l}-0.128^{* * *} \\
(-13.50)\end{array}$ & \\
\hline In_pxbptf_i & & $\begin{array}{l}-0.0566^{* * *} \\
(-7.340)\end{array}$ & $\begin{array}{l}-0.0882^{* * *} \\
(-10.33)\end{array}$ & & $\begin{array}{l}-0.0698^{* * *} \\
(-7.340)\end{array}$ & $\begin{array}{l}-0.103^{* * *} \\
(-10.33)\end{array}$ \\
\hline In_tfi_i & $\begin{array}{l}-0.234^{* * *} \\
(-21.84)\end{array}$ & & & $\begin{array}{l}-0.184^{* * *} \\
(-21.84)\end{array}$ & & \\
\hline Constant & $\begin{array}{l}1.361^{* * *} \\
(15.73)\end{array}$ & $\begin{array}{l}1.264^{* * *} \\
(14.62)\end{array}$ & $\begin{array}{l}1.320^{* * *} \\
(10.98)\end{array}$ & & & \\
\hline Observations & 9,093 & 9,093 & 8,801 & 9,093 & 9,093 & 8,801 \\
\hline R-squared & 0.624 & 0.624 & 0.626 & 0.624 & 0.624 & 0.626 \\
\hline Reporter FE & No & No & No & No & No & No \\
\hline Partner FE & Yes & Yes & Yes & Yes & Yes & Yes \\
\hline Clustered SE & Pair & Pair & Pair & Pair & Pair & Pair \\
\hline Adjusted R-squared & 0.618 & 0.617 & 0.619 & 0.618 & 0.617 & 0.619 \\
\hline
\end{tabular}

$\mathrm{FE}=$ fixed effects, $\mathrm{LSCl}=$ liner shipping connectivity index of country, $\mathrm{RTA}=$ regional trade agreement, $\mathrm{SE}=$ standard error, $\mathrm{TFI}=$ trade facilitation indicators. ${ }^{* * *} \mathrm{p}<0.01,{ }^{* *} \mathrm{p}<0.05,{ }^{*} \mathrm{p}<0.1$; t values in parentheses.

Source: ESCAP calculations using data from sources identified in Table 5. 
In terms of policy factors, tariffs, regional trade agreements, maritime connectivity, ease of financing and trade facilitation implementation indicators all have the expected and statistically significant impact on trade costs. Although tariffs have fallen considerably during the past decade, further reducing them globally remains an effective way to reduce trade costs. Indeed, the models suggest that a $10 \%$ change in tariff may be expected to reduce overall trade costs by more than $4 \%$ on average. The results also show a $10 \%$ increase in the overall implementation of trade facilitation measures will lead to $2.3 \%$ reduction in trade costs. This is nearly twice the trade cost reduction that may be expected by a $10 \%$ improvement in maritime connectivity (1.2\%).

\subsubsection{Simulation analysis}

Based on the trade cost model estimated earlier, this study investigated in greater detail the potential of trade facilitation measures in reducing trade costs across countries by conducting counterfactual simulations ("what if" analyses). In doing so, three groups of trade facilitation measures were considered: (a) measures that are binding under the WTO TFA; (b) measures that are binding under the WTO TFA as well as those included in the WTO TFA but are nonbinding; and (c) binding and nonbinding WTO TFA measures as well as other paperless trade measures not specifically included in the WTO TFA. ${ }^{17}$ The following two scenarios are considered for each group:

- Scenario 1: Partial trade facilitation implementation scenario. All countries that have either "not implemented" the trade facilitation measures considered or have implemented them "on a pilot basis", take action and achieve at least partial implementation;

- Scenario 2: Full trade facilitation implementation scenario. All countries that have not achieved full implementation of the trade facilitation measures considered take action and achieve full implementation.

Results of the simulations are shown in Table 7 for Asia and Pacific economies. Implementation of binding and nonbinding WTO TFA measures results in a $5 \%$ reduction in trade costs, on average, under a partial implementation scenario, and an $9 \%$ reduction under the more ambitious full implementation scenario. In contrast, implementing only binding WTO TFA measures results, at best, in about a $6 \%$ decrease in trade costs on average in these countries. Under a WTO TFA plus scenario, where paperless and crossborder paperless trade measures not included in the WTO TFA are implemented, the average trade cost reduction across countries increases to more than $16 \%$.

Table 7 also shows the average trade costs reduction of Asia and Pacific economies and the rest of the world associated with the different types of trade facilitation measures identified above. Both the partial and full implementation scenarios suggest that, among WTO TFA measures, those related to formalities will have the highest impact on trade costs on average, both in the case of binding and nonbinding measures. The largest reduction of trade costs, however, is achieved through partial or full implementation of paperless trade measures beyond those required or specified in the WTO TFA.

A useful finding from the counterfactual simulation is that many developing economies in Asia and the Pacific can expect only limited trade cost reductions from their own WTO TFA implementation, essentially because they have already implemented most of the measures featured in the agreement. This is particularly true for ASEAN and East Asian economies, where implementation of some of the most advanced measures featured in the WTO TFA — such as Single Windows-had been initiated well before the WTO TFA was concluded. For those countries, making significant progress in reducing trade costs through trade facilitation necessarily implies implementation of WTO TFA+ measures, such as those aimed at enabling electronic exchange of data and documents across countries and along international supply chains (i.e., cross-border paperless trade).

17 Details regarding allocation of the 31 trade facilitation measures included in this study to each of the three groups are provided in the Appendix. 
Table 7: International Trade Cost Changes in Asia and the Pacific Resulting from World Trade Organization Trade Facilitation Agreement Implementation

\begin{tabular}{|c|c|c|c|c|c|c|}
\hline \multirow[t]{2}{*}{ Asia and Pacific } & \multicolumn{2}{|c|}{$\begin{array}{l}\text { WTO TFA } \\
\text { (binding only) }\end{array}$} & \multicolumn{2}{|c|}{$\begin{array}{c}\text { WTO TFA } \\
\text { (binding + non binding) }\end{array}$} & \multicolumn{2}{|c|}{$\begin{array}{l}\text { WTO TFA+ } \\
\text { (binding + non binding + other } \\
\text { paperless and cross-border } \\
\text { paperless trade) }\end{array}$} \\
\hline & $\begin{array}{c}\text { Partially } \\
\text { implemented }\end{array}$ & $\begin{array}{c}\text { Fully } \\
\text { implemented }\end{array}$ & $\begin{array}{c}\text { Partially } \\
\text { implemented }\end{array}$ & $\begin{array}{c}\text { Fully } \\
\text { implemented }\end{array}$ & $\begin{array}{c}\text { Partially } \\
\text { implemented }\end{array}$ & $\begin{array}{c}\text { Fully } \\
\text { implemented }\end{array}$ \\
\hline \multicolumn{7}{|l|}{ Model 1} \\
\hline Overall TFI & $-2.70 \%$ & $-5.74 \%$ & $-4.64 \%$ & $-9.45 \%$ & $-10.37 \%$ & $-16.37 \%$ \\
\hline \multicolumn{7}{|l|}{ Model 3} \\
\hline Transparency & $-0.81 \%$ & $-1.74 \%$ & $-1.29 \%$ & $-3.27 \%$ & $-1.29 \%$ & $-3.27 \%$ \\
\hline Formalities & $-1.67 \%$ & $-2.93 \%$ & $-2.26 \%$ & $-4.00 \%$ & $-2.26 \%$ & $-4.00 \%$ \\
\hline Institution & $-0.41 \%$ & $-1.35 \%$ & $-0.41 \%$ & $-1.35 \%$ & $-1.37 \%$ & $-2.44 \%$ \\
\hline $\begin{array}{l}\text { Paperless and cross- } \\
\text { border paperless }\end{array}$ & - & - & $-1.39 \%$ & $-2.24 \%$ & $-6.73 \%$ & $-9.26 \%$ \\
\hline
\end{tabular}

TFI = trade facilitation implementation. WTO TFA = World Trade Organization Trade Facilitation Agreement.

Note: See appendix for nature and relationships between selected trade facilitation measures considered and the WTO TFA provisions

Source: ESCAP calculations using data from sources identified in Table 5.

To put these results into perspective, it is useful to contrast them with the trade costs reductions that may be associated with broader trade facilitation reforms, which often encompass measures aimed at improving trade-related infrastructure and services, and the overall business environment (World Trade Organization, 2015). In that context, the following additional counterfactual simulation was conducted as part of this study using the results of model 1 :

- Scenario 3: Improvement in maritime connectivity. All countries with $\mathrm{LSCl}$ scores below the developing country average/high income average act and bring their $\mathrm{LSCl}$ score to that level.

- Scenario 4: Improvement in access to financing. All countries with the Air Connectivity Index scores below the developing country average/high income average act and bring their index score to that level.

\section{Table 8: Trade Cost Changes in Asia and the Pacific Resulting from Port Connectivity and Trade} Finance Improvement

\begin{tabular}{|c|c|c|}
\hline Asia and Pacific & $\begin{array}{l}\text { Improve to Developing Economies' } \\
\text { Average }\end{array}$ & $\begin{array}{l}\text { Improve to High Income Economies' } \\
\text { Average }\end{array}$ \\
\hline Maritime connectivity & $-5.72 \%$ & $-7.80 \%$ \\
\hline Access to credit & $-0.41 \%$ & $-0.85 \%$ \\
\hline
\end{tabular}

Note: Counterfactual estimates based on Model 1 and assuming port connectivity and credit information levels are brought up to the developing economies/OECD average.

Source: ESCAP calculations using data from sources identified in Table 5. 
As Table 8 shows, the simulation results suggest that improvement in maritime connectivity, as described in scenario 3, would reduce trade costs in Asia and the Pacific by $6 \%$ and overall international trade costs of the region by nearly $8 \%$, while improved access to finance through improvement in access to credit (scenario 4) could reduce trade costs by $0.4 \%$ to $0.9 \% .^{18}$ Taken together, the size of the trade cost reductions associated with these broader trade facilitation measures appears to be very significant, although they cannot be easily compared to those associated with the narrower WTO TFA and paperless trade measures. This is not unexpected and is, in fact, consistent with earlier findings from the literature that improvements in port efficiency and the overall business environment are essential to reducing international trade costs and enabling firms to efficiently conduct international transactions.

\subsubsection{Summary}

Data analysis in this section indicates that trade cost savings for Asia and the Pacific from even partial implementation of both binding and nonbinding WTO TFA measures could reach at least $\$ 219$ billion a year. ${ }^{19}$ However, reductions in trade costs in developing countries that have long been involved in simplifying, harmonizing, and automating trade procedures at the national and subregional level may be relatively small from WTO TFA, in that trade facilitation in those countries is already advanced. Further facilitation of trade in these economies will involve developing legal and technical frameworks to support cross-border paperless trade, that is, enabling the electronic exchange and legal recognition of trade data and documents between public and private actors located in different countries along the international supply chain. However, such efforts should take place within the context of broader trade facilitation programs and strategies encompassing trade-related infrastructure and services, particularly those related to port connectivity.

\subsection{Trade Facilitation Impact on Trade Flows: Evidence from Central Asia}

\subsubsection{Background: Trade facilitation indicators in Central Asia Regional Economic Cooperation}

The Corridor Performance Measurement and Monitoring Trade Facilitation Indicators (CPMM TFI) aim to measure and monitor corridor performance by providing the time and costs indicators of trade and transport facilitation performance in the CAREC region to identify transport inefficiency and bottlenecks. The CPMM TFIs are a specific set of indicators to assess the overall performance of the six CAREC corridors. The indicators cover four areas of time-cost-distance (measured in hours or days-\$-kilometers) of trading in common economic corridors: TFI1, time taken to clear a border crossing point; TF2, costs incurred at a border crossing point; TF3, costs incurred while traveling along a corridor section; TFI4 and TFI5, speed of travel along a corridor section (ADB 2014b) (Table 9).

For empirical analysis, we used the CPMM TFIs data available at a very detailed level, that is, the level of border crossing points. Since the majority of trade occurring within Central Asia goes through either (both) road or (and) rail, it is expected that the cost/time taken at the border crossing points account for the majority of trade costs other than fuel costs for trucks and trains. To our knowledge, no study has taken advantage of the CPMM TFls, except for Tanabe et al. (2016). ${ }^{20}$ It is worth noting that even in Tanabe et al. (2016), they simply use the aggregate summary data to calibrate a transport network computable general equilibrium model.

18 These estimates are calculated based on the same group of countries as in earlier simulations. That is, they include a significant number of Asia and Pacific developing countries that see no individual cost reductions under the scenarios considered, since their maritime connectivity and credit information systems are already at or above the developing economies' average (or the even the high-income average in the case of access to credit index). A more detailed analysis at the country level reveals that the trade cost reductions from improvements in maritime connectivity for belowaverage countries are significantly larger than those from WTO TFA implementation.

19 Trade cost savings estimate rise to $\$ 1,328.4$ billion a year if full implementation of a WTO TFA+ package of measures can be achieved.

20 Unlike other global trade facilitation indexes available annually in general, the CPMM TFIs are available quarterly as well as annually, by the economic corridor (1-6) and by mode of transportation (road and rail). Furthermore, considering that the majority of trade flows within the CAREC countries are occurring through the economic corridors by land transportation, the CPMM TFIs are more representative trade facilitation measures for the landlocked countries. 


\section{Table 9: Corridor Performance Measurement and Monitoring Trade Facilitation Indicators}

\begin{tabular}{ll} 
TFI1 & $\begin{array}{l}\text { Time taken to clear a border crossing point (hours) } \\
\text { Average length of time (hours) it takes to move cargo (20 tons) across a border from the exit } \\
\text { point of one country to the entry point of another; to capture both the complexity and the } \\
\text { inefficiencies inherent in the border crossing process. }\end{array}$ \\
\hline TFI2 & $\begin{array}{l}\text { Cost incurred at border crossing clearance }(\$) \\
\text { Average total cost }(\$) \text { of moving cargo (20 tons) across a border from the exit point of one } \\
\text { country to the entry point of another; Both official and unofficial payments are included. }\end{array}$ \\
& $\begin{array}{l}\text { Cost incurred to travel a corridor section (per } 500 \text { kilometer per } 20 \text {-ton cargo) } \\
\text { Average total cost (\$) incurred for a unit of cargo (a cargo truck or train with } 20 \text { tons of goods) } \\
\text { traveling along a corridor section within a country or across borders. Both official and unofficial } \\
\text { payments are included. }\end{array}$ \\
\hline TFI3 & $\begin{array}{l}\text { Speed to travel with delay on CAREC corridors (kilometers per hour), (speed with delay) } \\
\text { Average speed (kilometers per hour) at which a unit of cargo travels along a corridor section (a } \\
\text { stretch of road } 500 \text { kilometer long) within a country or across borders. The total time taken for } \\
\text { the entire journey. Distance and time measurements include border crossings. An indicator of } \\
\text { the efficiency of border crossing points along the corridors. }\end{array}$ \\
\hline TFI4 & $\begin{array}{l}\text { Speed to travel without delay on CAREC corridors (kilometers per hour)-(speed without } \\
\text { delay) } \\
\text { Traveling speed only. A measure of the condition of physical infrastructure (such as road and } \\
\text { railways). }\end{array}$ \\
\hline TFI5 &
\end{tabular}

Source: Asian Development Bank. 2014b.

\subsubsection{Methodology: Gravity model}

To evaluate the impact of trade facilitation activities on trade in Central Asia, the gravity model of bilateral trade is used. Based on Anderson and van Wincoop (2003), we include exogenous trade costs, timevarying country fixed effects, and endogenous trade costs. In addition, to determine the trade intensities within the economic corridors in the region, "corridor" dummies are included. The following gravity model is specified as follows:

$$
\log Y_{i j t}=\alpha+\boldsymbol{\gamma} \cdot \mathbf{X}_{i j}+\boldsymbol{\theta} \cdot \mathbf{Z}_{i j t}+\boldsymbol{\delta}_{i} \cdot \mathbf{F}_{i t}+\boldsymbol{\delta}_{j} \cdot \mathbf{F}_{j t}+\sum_{i=1}^{6} \rho(k) C_{i j(k)}+v_{i j t}
$$

where $\mathbf{Y}_{i j t}$ is the exports of country $i$ to country $j$. On the right-hand side of the equation, the vector, $\mathbf{X}_{i j}$ captures the exogenous trade cost variables, which are the time-invariant variables in the gravity model such as distance, colony, language, and contiguity. On the other hand, the vector, $\mathbf{Z}_{i j t}$ consists of the endogenous variables, which are trade facilitation variables. Both $\boldsymbol{\gamma}$ and $\boldsymbol{\theta}$ are the vector of coefficients that measures the impact of the exogenous and endogenous trade costs on bilateral trade flows.

To account for time-varying characteristics of each trading partner, fixed effects interacted with year dummies are included in the model. The vectors, $\mathbf{F}$ it and $\mathbf{F} \boldsymbol{j t}$ capture all unobserved time-varying country effects that can enhance or deter trade. This effectively captures both outward and inward multilateral trade resistance factors, otherwise left out in the traditional gravity models, such as gross domestic product, population, and proximity or remoteness of countries. The corridor dummies, $\mathrm{C}_{i j}(k)$ indicate whether the pair of countries $i$ and $j$ belong to the same $k^{\text {th }}$ corridor, where $k=1,2, \ldots, 6$, representing the 6 corridors in CAREC. The pair of countries participation in the corridors is mutually exclusive, that is, a pair of countries could be part of several corridors (Table 10). 


\section{Table 10: Variables in the Gravity Model}

\begin{tabular}{l|l|l}
\hline Variable & Description & Expected Sign \\
\hline Dependent: & & \\
$\begin{array}{ll}\text { 1. Goods import or } & \text { Direction of Trade Statistics of the International Monetary } \\
\text { 2. Goods export } & \text { Fund (DOTS-IMF) }\end{array}$
\end{tabular}

Independent:

1. $\mathrm{X}_{i j}$ - vector of exogenous trade costs (CEPII)

a. Bilateral distance Measures in (natural logarithmic) terms of metric units, specifically kilometers, how far one country and its capital city is to another.

b. Contiguity

A dummy variable indicating that countries $i$ and $j$ are sharing the same border. It is expected that countries that are contiguous have higher trade flows than countries far apart.

c. Common Language

A dummy variable indicating that countries $i$ and $j$ share a common language. The costs of transactions are reduced if no language barriers exist between two trading countries.

d. Colonial relationship

A dummy variable indicating that countries $i$ and $j$ have a colonial relationship. This could reflect the historical trade between two countries.

2. $Z_{i j}$ - vector of endogenous trade costs

a. Trade Facilitation Variables under this category would show the impact of complexity and inefficiencies in facilitating trade between countries.

i. Clearing time in border Length of time it takes to move a cargo across a border crossing points (BCP) - from the exit point of country i to entry point of country inbound and outbound j. This measurement includes waiting time, unloading or loading time, and time taken to change rail gauges, among other indicators. This indicator measures complexity and inefficiencies in the border crossing process. Intuitively, if clearing time is minimal, trade would easily flow across borders.

ii. Costs incurred at Cost of moving a cargo across a border from the exit point a BCP-inbound and of country i to entry point of country j. Low costs would encourage more trade flows among countries.

outbound

Count variable of the BCPs crossed in bilateral trade. The number of points crossed can be a resistance to trade since each point can hamper speed and increase costs for trade.

\section{3. $C_{i j}(k)$ - vector of corridor dummies}

a. Corridor 1

b. Corridor 2

c. Corridor 3

d. Corridor 4

e. Corridor 5

f. Corridor 6
A dummy variable for Europe-East Asia corridor

A dummy variable for Mediterranean-East Asia corridor

A dummy variable for Russian Federation-Middle East Asia and South Asia corridor

A dummy variable for Russian Federation-East Asia corridor

A dummy variable for East Asia-Middle East Asia and South Asia corridor

A dummy variable for Europe-Middle East Asia and South Asia corridor
+ indicates more trade. High positive values indicate high trade intensity

Sources: Direction of Trade Statistics of the International Monetary Fund, CEPII, and authors' calculations based on the data provided by the CAREC program. 
Along with the OLS, the estimation of the econometric model is conducted using the Heckman method to address sample selection bias and inconsistency of estimators. The first stems from the automatic dropping of observations with zero trade flows, since logarithm of zero is undefined. The second is a consequence of the former. If the model was run using OLS, implying that the estimation considered strictly positive values of trade flows only, then there is a case of omitted variables. The lack of a variable that defines the probability of trading (i.e., including zero trade flows) results in the correlation of the error term and some independent variables (e.g. trade costs). The Heckman method begins by estimating the probability of selection variable (i.e., probability of trading with another country) using the probit method. ${ }^{21}$ The results from the selection equation will then be used to estimate the econometric specification above to correct the omitted variable bias, and produce unbiased and consistent estimates. We present the Heckman estimation together with the OLS estimation to explore the robustness of results by the choice of an estimation method.

\subsubsection{Data for analysis}

For further analysis, trade facilitation indicators should be available at least at the country level since the variable of interest, trade flow data, are generally available at the bilateral country level. Thus, time (TFI1) and cost (TFI2) measures are utilized since these are the only data available at the border-crossing points, ultimately to be aggregated by country. At each border crossing point in the CAREC countries, there exist two types information for each of average time and cost taken: in- and out-bound (Figure 12). ${ }^{22}$ There are multiple crossing points along each of the six economic corridors in CAREC. This directional information makes it possible to compile time and cost taken at the border to export and import at a given border crossing point pair.

To obtain country-paired data for time and cost taken at the border, given exporter-importer border crossing point pairs, we take the unweighted ${ }^{23}$ average of outbound time (and cost) data points within the exporting country. Likewise, means of inbound time (and cost) is calculated within the importing country. Then, the resulting out- and in-bound time and cost for the exporter-import pair can be matched with the bilateral trade flows. For non-contiguous trading partners, potential inland routes are identified first based on the corridor maps, then the same approach mentioned above is implemented for the border crossing points along the identified corridor routes. In addition to average time and costs taken at the crossing points, the number of border crossing points is also considered in the model since it tends to increase for non-contiguous countries.

To illustrate, in Figure 12, for contiguous countries, trade flows from countries B to C (blue arrows) can be matched with (1) average time taken at the exporter B's border crossing points (average of $\mathrm{t}^{\mathrm{B}}$ out and $\mathrm{t}^{\mathrm{B}}$ out 2 ); and (2) average time taken at the importer C's border crossing points (average of $\mathrm{t}^{\mathrm{C}}$ in and $\mathrm{t}^{\mathrm{C}}$ in2). For non-contiguous trade partners, two potential routes exist connecting Countries A and C: Corridors 1 and 2. Therefore, exports from A to B can be matched with (1) average time taken at the outbound border crossing points on Corridors 1 \& 2 (average of avg $\left(\mathrm{t}^{\mathrm{A}}\right.$ out, $\mathrm{t}^{\mathrm{B}}$ out 1$)$ and $\operatorname{avg}\left(\mathrm{t}^{\mathrm{A}}\right.$ out, $\mathrm{t}^{\mathrm{B}}$ out 2$)$ ); and (2) average time taken at the inbound border crossing points on Corridors $1 \& 2$ (average of avg $\left(\mathrm{t}^{\mathrm{B}} \mathrm{in}, \mathrm{t}^{\mathrm{C}} \mathrm{in1}\right)$ and $\operatorname{avg}\left(\mathrm{t}^{\mathrm{B}} \mathrm{in}, \mathrm{t}^{\mathrm{C}} \mathrm{in} 2\right)$ ).

21 In the selection equation, we use a common colonizer dummy (whether the trading partners had a common colonizer in the past) as an instrumental variable.

22 For road, out of 77 border crossing point samples in the CAREC region, we only chose 61 border crossing points with non-missing data. For rail, however, there are only 13 border crossing point samples with non-missing data, which is not sufficient for conducting further analysis. Medians of time and costs are also available, but main findings using these measures change little.

23 Arguably, transit flows at each border crossing point are more accurate weights to consider for aggregation. However, a complete set of transit flow data at all border crossing points is not available. 


\section{Figure 12: Diagram for Border Crossing Point Data Structure}

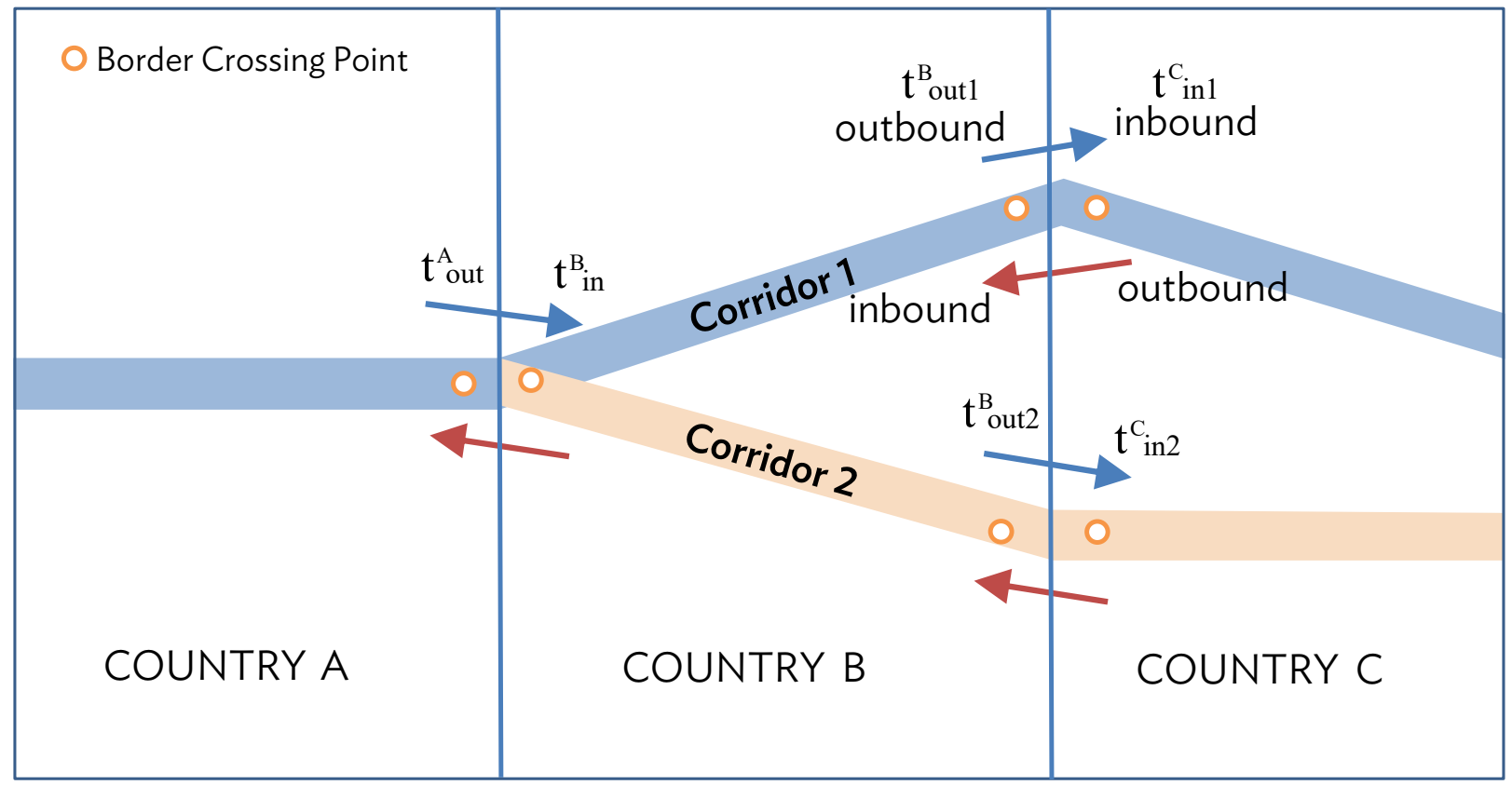

Source: Authors

\subsubsection{Estimation results}

The estimation results show that average time (hours) taken at a border crossing point are more important than average costs (US dollar) incurred at a border crossing point in determining the bilateral trade flows within the CAREC region (Table 11). ${ }^{24}$ This finding is statistically significant. One potential explanation is that the monetary measure in nominal terms may not be a representative measure for trade facilitation performance at the border since it cannot rule out the influences from inflation, ${ }^{25}$ foreign exchange rates, and unofficial border crossing fees incurred irregularly to ensure a "smooth journey". ${ }^{26}$

Average time taken at the border crossing points of importing countries (inbound border crossing point) is a more important determinant of trade flow than that at the crossing points of exporting countries (outbound border crossing point) (Col1-3, Table 11). Only the time taken at the inbound border crossing points is negative and significant (Col 1-3), while neither average time at the outbound border crossing points nor total average time taken at the border (inbound plus outbound) has any statistically significant impact on trade flows in the most preferred Heckman estimation (Col 6 and 8). Relative to outbound border crossing points, inbound crossing points are more important for the following reasons: (1) much of the cost and delay may be incurred at inbound border crossing points (GIZ2011), and (2) more safety risks and infrastructure deterioration could occur at inbound border crossing points since inbound trucks are often overloaded (UNDP 2014); and (3) the inbound logistics could directly affect local manufacturers (Arnold 2007) who are responsible for transporting their imports from the border crossing point to their factories.

24 The results shown here are for road only. The lack of data for rail prevented us from doing the same analysis. For analysis, the observations with average time taken above 60 hours - chosen from the historical maximum of average time taken which covers the majority of observations-were omitted to minimize the impact of sudden, irregular delays occurring at a few border crossing points.

25 Central Asia has been experiencing elevated inflation, including a rise from 5.9\% in 2014 to $11.1 \%$ in 2016 - compared to that of developing Asia, which declined from 3.0\% in 2014 to 2.5\% in 2016 (ADB 2017c). Other than inflation, oil prices subject to international supply and demand are also a crucial factor for costs measured along the economic corridors. However, the cost incurred at the border currently used in this section is not affected by oil prices.

26 The existence of these unofficial payments is frequently mentioned in the official reports of the CAREC CPMM. 
The negative coefficients in Col 1-3, Table 11 imply that reducing the time taken at the importers' border crossing points by $10 \%$ is associated with an increase in trade flows of $2 \%-3 \%$. Given the very wide range of estimated gains in interregional trade from trade facilitation in Central Asia varying by type of trade facilitation activities, our estimates could form a lower bound of trade facilitation efforts at the border. When it comes to the costs incurred at the border crossing points (Table 12), the costs at the inbound crossing points do not have any significant impact on trade, and the cost at the outbound border crossing points do even show positive signs but the magnitude becomes smaller to a large extent when the Heckman estimation is used.

Other than the above-mentioned variables of interest, traditional exogenous variables in the gravity model generally point to the same direction, consistent with the literature.

- The estimated negative relationship between distance and trade flows is very significant and consistent with other studies. Just to examine the impact of the number of border crossing points passed along the corridors, the results (Col 2 and 5, Table 11; Col 2, Table 12) confirm that an increase in the number of border crossing points passed for bilateral trade decreases trade flows, although the magnitude of the impact is not separable from the impact of distance, when the distance variable is omitted, accounting for its high correlation with the number of border crossing points.

- Being contiguous to each other is shown to create more bilateral trade, while It turns out that to have a common language is not one of the major determinants for trade among the CAREC countries, unlike what is commonly found in similar studies. Among 11 CAREC countries, only Kazakhstan and the Kyrgyz Republic use Russian as a common language (and both countries share a border). Therefore, the coefficient on the common language could be simply treated as dummy variables for these two countries.

- Lastly, one interesting finding is the negative relationship between the colonial status and trade flow, while this normally shows a positive sign in the literature. However, as for the common language, one should avoid interpreting this as generalized impact of colonial relationship, since only two countries, the PRC and Mongolia, are under this situation.

\subsubsection{Simulation exercise}

To evaluate trade gains from time reduction at the border in economic terms, a simple simulation exercise is conducted based on the Heckman model in column 3, Table 11 (Table 13).

The simulation results imply that if the time taken at the importers' border crossing points is reduced by $10 \%,{ }^{27}$ total gains in intra-CAREC trade in goods would be $\$ 1.442$ billion (based on the 2015 figures). When the economic size is considered, the economic impact of reduction in border clearance time seems minimal. The 2015 intraregional trade within the CAREC region accounts for only $0.56 \%$ of CAREC GDP (1.2\% excluding the PRC). The estimated trade gains of $\$ 1.442$ billion are equivalent to 0.01 percentage point of the CAREC GDP (0.09 percentage point excluding PRC).

It is, however, worthwhile to note that trade gains vary by individual CAREC member country. The countries with higher interregional trade shares against the GDPs tend to earn higher trade gains from time reduction at the border crossing points than the countries with lower interregional trade shares. For example, the top 3 exporters with the highest intraregional exports shares - Mongolia, Turkmenistan, and the Kyrgyz Republic - get the highest benefits, 0.73, 0.50, and 0.14 percentage of their GDPs, respectively.

27 When 2016 is used for the calculation, the total intraregional trade gain becomes $\$ 1.472$ billion, i.e. $2.2 \%$ of $\$ 62.5$ billion. 
Table 11: Gravity Model Estimation: Time Taken (hours) at Border Crossing Points (road) on Bilateral Exports

\begin{tabular}{|c|c|c|c|c|c|c|c|c|}
\hline $\begin{array}{l}\text { Dependent variable: } \\
\text { Log(exports) }\end{array}$ & $\begin{array}{l}\text { (1) } \\
\text { OLS }\end{array}$ & $\begin{array}{l}\text { (2) } \\
\text { OLS }\end{array}$ & $\begin{array}{c}\text { (3) } \\
\text { Heckman }\end{array}$ & $\begin{array}{l}\text { (4) } \\
\text { OLS }\end{array}$ & $\begin{array}{l}\text { (5) } \\
\text { OLS }\end{array}$ & $\begin{array}{c}(6) \\
\text { Heckman }\end{array}$ & $\begin{array}{l}\text { (7) } \\
\text { OLS }\end{array}$ & $\begin{array}{c}(8) \\
\text { Heckman }\end{array}$ \\
\hline Log(distance) & $\begin{array}{r}-1.483^{* * *} \\
(-5.07)\end{array}$ & & $\begin{array}{r}-1.473^{* *} \\
(-2.49)\end{array}$ & $\begin{array}{r}-1.634^{* * *} \\
(-5.46)\end{array}$ & & $\begin{array}{r}-1.625^{* * *} \\
(-2.73)\end{array}$ & $\begin{array}{r}-1.579^{* * *} \\
(-5.30)\end{array}$ & $\begin{array}{r}-2.276^{* * *} \\
(-4.25)\end{array}$ \\
\hline Colonial relationship ${ }^{1}$ & $\begin{array}{r}-6.058^{* * *} \\
(-6.95)\end{array}$ & $\begin{array}{r}-3.671^{* * *} \\
(-5.38)\end{array}$ & $\begin{array}{r}-6.028^{* * *} \\
(-3.94)\end{array}$ & $\begin{array}{r}-6.380^{* * *} \\
(-7.11)\end{array}$ & $\begin{array}{r}-3.809^{* * *} \\
(-5.34)\end{array}$ & $\begin{array}{r}-6.351^{* * *} \\
(-3.92)\end{array}$ & $\begin{array}{r}-6.324^{* * *} \\
(-7.17)\end{array}$ & $\begin{array}{r}-4.416^{* * *} \\
(-2.57)\end{array}$ \\
\hline Common language 2 & $\begin{array}{r}-1.401^{* * *} \\
(-2.77)\end{array}$ & $\begin{array}{l}0.434 \\
(1.23)\end{array}$ & $\begin{array}{l}-1.388 \\
(-1.19)\end{array}$ & $\begin{array}{r}-1.117^{* *} \\
(-2.17)\end{array}$ & $\begin{array}{r}0.920^{* *} \\
(2.40)\end{array}$ & $\begin{array}{r}-1.106 \\
(-0.95)\end{array}$ & $\begin{array}{r}-1.432^{* * *} \\
(-2.81)\end{array}$ & $\begin{array}{r}-2.286^{*} \\
(-1.92)\end{array}$ \\
\hline Contiguity & $\begin{array}{l}0.457^{* *} \\
(2.00)\end{array}$ & $\begin{array}{r}0.941^{* * *} \\
(4.99)\end{array}$ & $\begin{array}{l}0.462 \\
(0.84)\end{array}$ & $\begin{array}{l}0.439^{*} \\
(1.93)\end{array}$ & $\begin{array}{r}0.987^{* * *} \\
(5.23)\end{array}$ & $\begin{array}{l}0.444 \\
(0.81)\end{array}$ & $\begin{array}{r}0.450^{* *} \\
(1.97)\end{array}$ & $\begin{array}{r}0.760^{*} \\
(1.77)\end{array}$ \\
\hline \#BCPs passed & $\begin{array}{r}-0.0748 \\
(-1.37)\end{array}$ & $\begin{array}{r}-0.184^{* * *} \\
(-3.44)\end{array}$ & $\begin{array}{l}-0.076 \\
(-0.63)\end{array}$ & $\begin{array}{r}-0.0897 \\
(-1.63)\end{array}$ & $\begin{array}{r}-0.216^{* * *} \\
(-3.82)\end{array}$ & $\begin{array}{l}-0.090 \\
(-0.74)\end{array}$ & $\begin{array}{r}-0.0819 \\
(-1.50)\end{array}$ & $\begin{array}{l}0.024 \\
(0.24)\end{array}$ \\
\hline $\begin{array}{l}\text { Log(Avg time at } \\
\text { outbound BCPs) }\end{array}$ & & & & $\begin{array}{l}0.216^{* *} \\
(2.07)\end{array}$ & $\begin{array}{l}0.185^{*} \\
(1.71)\end{array}$ & $\begin{array}{l}0.216 \\
(1.39)\end{array}$ & & \\
\hline $\begin{array}{l}\text { Log(Avg time at } \\
\text { inbound } B C P s \text { ) }\end{array}$ & $\begin{array}{r}-0.221^{* * *} \\
(-2.60)\end{array}$ & $\begin{array}{r}-0.304^{* * *} \\
(-3.44)\end{array}$ & $\begin{array}{c}-0.220^{* *} \\
(-2.08)\end{array}$ & & & & & \\
\hline $\begin{array}{l}\text { Log(Total avg } \\
\text { time at BCPs) }\end{array}$ & & & & & & & $\begin{array}{l}-0.0563 \\
(-0.52)\end{array}$ & $\begin{array}{l}0.236 \\
(1.42)\end{array}$ \\
\hline Constant & $\begin{array}{l}24.58^{* * *} \\
(13.24)\end{array}$ & $\begin{array}{l}15.14^{* * *} \\
(24.24)\end{array}$ & $\begin{array}{r}24.53^{* * *} \\
(6.33)\end{array}$ & $\begin{array}{r}25.29^{* * *} \\
(13.53)\end{array}$ & $\begin{array}{l}14.83^{* * *} \\
(24.26)\end{array}$ & $\begin{array}{r}25.237^{* * *} \\
(6.55)\end{array}$ & $\begin{array}{r}25.10^{* * *} \\
(13.45)\end{array}$ & $\begin{array}{r}28.385^{* * *} \\
(8.07)\end{array}$ \\
\hline Corridor $\mathrm{FE}^{3}$ & Yes & Yes & Yes & Yes & Yes & Yes & Yes & Yes \\
\hline Exporter $x$ Year FE & Yes & Yes & Yes & Yes & Yes & Yes & Yes & Yes \\
\hline Importer $x$ Year FE & Yes & Yes & Yes & Yes & Yes & Yes & Yes & Yes \\
\hline Observations & 1,045 & 1,045 & 1,273 & 1,045 & 1,045 & 1,273 & 1,045 & 1,273 \\
\hline Censored observations & 228 & 228 & 228 & 228 & 228 & 228 & 228 & 228 \\
\hline
\end{tabular}

$\mathrm{BCP}=$ border crossing point, $\mathrm{FE}=$ fixed effects, $\mathrm{OLS}=$ ordinary least squares.

1 Only the People's Republic of China and Mongolia have colonial relationship.

2 Only Kazakhstan and the Kyrgyz Republic use Russian as a common language.

3 Corridor dummies $=1$ if both exporting and importing countries belong in an economic corridor.

Note:

$\mathrm{t}$ values in parentheses. Heckman selection estimation was used to account for missing bilateral economy-pair data: a common colonizer dummy

(whether the trading partners had a common colonizer in the past) was used as an instrumental variable.

${ }^{* * *} p<0.01,{ }^{* *} p<0.05,{ }^{*} p<0.1$

Source: ADB calculations using data from sources identified in Table 10. 
Table 12: Gravity Model Estimation: Impact of Average Cost (in \$) at Border Crossing Points (road) on Bilateral Exports

\begin{tabular}{|c|c|c|c|c|c|c|c|c|}
\hline $\begin{array}{l}\text { Dependent variable: } \\
\text { Log(exports) }\end{array}$ & $\begin{array}{l}\text { (1) } \\
\text { OLS }\end{array}$ & $\begin{array}{l}\text { (2) } \\
\text { OLS }\end{array}$ & $\begin{array}{c}\text { (3) } \\
\text { Heckman }\end{array}$ & $\begin{array}{l}(4) \\
\text { OLS }\end{array}$ & $\begin{array}{l}\text { (5) } \\
\text { OLS }\end{array}$ & $\begin{array}{c}(6) \\
\text { Heckman }\end{array}$ & $\begin{array}{l}\text { (7) } \\
\text { OLS }\end{array}$ & $\begin{array}{c}(8) \\
\text { Heckman }\end{array}$ \\
\hline Log(distance) & $\begin{array}{r}-1.414^{* * *} \\
(-4.97)\end{array}$ & & $\begin{array}{c}-2.257^{* * *} \\
(-4.20)\end{array}$ & $\begin{array}{r}-1.732^{* * *} \\
(-5.07)\end{array}$ & & $\begin{array}{r}-2.225^{* * *} \\
(-4.17)\end{array}$ & $\begin{array}{r}-1.503^{* * *} \\
(-4.22)\end{array}$ & $\begin{array}{r}-2.331^{* * *} \\
(-3.86)\end{array}$ \\
\hline Colonial relationship ${ }^{1}$ & $\begin{array}{r}-5.754^{* * *} \\
(-6.67)\end{array}$ & $\begin{array}{r}-3.324^{* * *} \\
(-4.90)\end{array}$ & $\begin{array}{r}-4.253^{* *} \\
(-2.50)\end{array}$ & $\begin{array}{r}-6.782^{* * *} \\
(-6.70)\end{array}$ & $\begin{array}{r}-3.765^{* * *} \\
(-5.15)\end{array}$ & $\begin{array}{r}-4.006^{* *} \\
(-2.26)\end{array}$ & $\begin{array}{r}-6.006^{* * *} \\
(-5.74)\end{array}$ & $\begin{array}{l}-4.381^{* *} \\
(-2.30)\end{array}$ \\
\hline Common language $^{2}$ & $\begin{array}{r}-1.307^{* * *} \\
(-2.62)\end{array}$ & $\begin{array}{l}0.405 \\
(1.06)\end{array}$ & $\begin{array}{l}-2.316^{*} \\
(-1.92)\end{array}$ & $\begin{array}{r}-1.133^{* *} \\
(-2.17)\end{array}$ & $\begin{array}{r}0.985^{* * *} \\
(2.61)\end{array}$ & $\begin{array}{l}-2.143^{*} \\
(-1.80)\end{array}$ & $\begin{array}{r}-1.273^{* *} \\
(-2.35)\end{array}$ & $\begin{array}{l}-2.261^{*} \\
(-1.74)\end{array}$ \\
\hline Contiguity & $\begin{array}{l}0.366 \\
(1.61)\end{array}$ & $\begin{array}{r}0.815^{* * *} \\
(4.36)\end{array}$ & $\begin{array}{r}0.7597^{*} \\
(1.75)\end{array}$ & $\begin{array}{r}0.313 \\
(1.26)\end{array}$ & $\begin{array}{r}0.917^{* * *} \\
(4.52)\end{array}$ & $\begin{array}{r}0.755^{*} \\
(1.76)\end{array}$ & $\begin{array}{l}0.222 \\
(0.87)\end{array}$ & $\begin{array}{l}0.630 \\
(1.40)\end{array}$ \\
\hline \#BCPs passed & $\begin{array}{r}-0.0698 \\
(-1.30)\end{array}$ & $\begin{array}{r}-0.154^{* * *} \\
(-2.85)\end{array}$ & $\begin{array}{l}0.031 \\
(0.31)\end{array}$ & $\begin{array}{l}-0.0331 \\
(-0.60)\end{array}$ & $\begin{array}{c}-0.135^{* *} \\
(-2.24)\end{array}$ & $\begin{array}{l}0.038 \\
(0.39)\end{array}$ & $\begin{array}{r}-0.00467 \\
(-0.09)\end{array}$ & $\begin{array}{l}0.032 \\
(0.31)\end{array}$ \\
\hline $\begin{array}{l}\text { Log(Avg cost at } \\
\text { outbound BCPs) }\end{array}$ & & & & $\begin{array}{r}0.318^{* * *} \\
(3.06)\end{array}$ & $\begin{array}{r}0.351^{* * *} \\
(3.26)\end{array}$ & $\begin{array}{c}0.037^{*} \\
(1.65)\end{array}$ & & \\
\hline $\begin{array}{l}\text { Log(Avg cost at } \\
\text { inbound BCPs) }\end{array}$ & $\begin{array}{r}-0.0346 \\
(-0.24)\end{array}$ & $\begin{array}{r}-0.0841 \\
(-0.55)\end{array}$ & $\begin{array}{l}-0.007 \\
(-0.51)\end{array}$ & & & & & \\
\hline $\begin{array}{l}\text { Log(Total avg } \\
\text { cost at BCPs) }\end{array}$ & & & & & & & $\begin{array}{l}0.194 \\
(1.22)\end{array}$ & $\begin{array}{l}0.263 \\
(1.06)\end{array}$ \\
\hline Constant & $\begin{array}{r}24.21^{* * *} \\
(12.91)\end{array}$ & $\begin{array}{r}15.34^{* * *} \\
(15.79)\end{array}$ & $\begin{array}{r}28.708^{* * *} \\
(8.06)\end{array}$ & $\begin{array}{r}23.99^{* * *} \\
(11.21)\end{array}$ & $\begin{array}{r}12.70^{* * *} \\
(15.64)\end{array}$ & $\begin{array}{r}28.368^{* * *} \\
(8.08)\end{array}$ & $\begin{array}{r}22.80^{* * *} \\
(9.29)\end{array}$ & $\begin{array}{r}27.877^{* * *} \\
(6.95)\end{array}$ \\
\hline Corridor $\mathrm{FE}^{3}$ & Yes & Yes & Yes & Yes & Yes & Yes & Yes & Yes \\
\hline Exporter $\mathrm{x}$ Year FE & Yes & Yes & Yes & Yes & Yes & Yes & Yes & Yes \\
\hline Importer x Year FE & Yes & Yes & Yes & Yes & Yes & Yes & Yes & Yes \\
\hline Observations & 1035 & 1035 & 1273 & 1023 & 1023 & 1273 & 1013 & 1216 \\
\hline Censored observations & 228 & 228 & 228 & 228 & 228 & 228 & 203 & 203 \\
\hline
\end{tabular}

$\mathrm{BCP}=$ border crossing point, $\mathrm{FE}=$ fixed effects, $\mathrm{OLS}=$ ordinary least squares.

1 Only the People's Republic of China and Mongolia have colonial relationship.

2 Only Kazakhstan and the Kyrgyz Republic use Russian as a common language.

3 Corridor dummies $=1$ if both exporting and importing countries belong in an economic corridor.

Note:

$\mathrm{t}$ values in parentheses. Heckman selection estimation was used to account for missing bilateral economy-pair data: a common colonizer dummy (whether the trading partners had a common colonizer in the past) was used as an instrumental variable.

${ }_{* * *} p<0.01,{ }^{* *} p<0.05,{ }^{*} p<0.1$

Source: ADB calculations using data from sources identified in Table 10. 
Table 13: Trade Gains from Time Reduction at Border Crossing Points

\begin{tabular}{|c|c|c|c|c|c|}
\hline CAREC Country & $\begin{array}{l}2015 \text { GDP at } \\
\text { Current Prices (\$ } \\
\text { billion) }\end{array}$ & $\begin{array}{l}2015 \text { Goods } \\
\text { Exports to CAREC } \\
\text { Countries } \\
\text { (\$ billion) }\end{array}$ & $\%$ GDP & $\begin{array}{l}\text { Trade Gains } \\
\text { from 10\% Time } \\
\text { Reduction at } \\
\text { Importer Border } \\
\text { Crossing Point (\$ } \\
\text { billion) }\end{array}$ & $\%$ GDP \\
\hline Afghanistan & 19.33 & 0.253 & 1.31 & 0.006 & 0.03 \\
\hline Azerbaijan & 53.05 & 0.676 & 1.28 & 0.015 & 0.03 \\
\hline Kazakhstan & 184.39 & 8.035 & 4.36 & 0.177 & 0.10 \\
\hline Kyrgyz Republic & 6.57 & 0.407 & 6.19 & 0.009 & 0.14 \\
\hline Mongolia & 11.74 & 3.902 & 33.23 & 0.086 & 0.73 \\
\hline Pakistan & 271.05 & 3.734 & 1.38 & 0.082 & 0.03 \\
\hline Tajikistan & 7.85 & 0.256 & 3.26 & 0.006 & 0.07 \\
\hline Turkmenistan & 35.86 & 8.163 & 22.77 & 0.180 & 0.50 \\
\hline Uzbekistan & 66.73 & 2.405 & 3.60 & 0.053 & 0.08 \\
\hline Georgia & 13.97 & 0.537 & 3.85 & 0.012 & 0.08 \\
\hline PRC & $11,065.00$ & 37.182 & 0.34 & 0.818 & 0.01 \\
\hline Total & 11735.54 & 65.55 & 0.56 & 1.442 & 0.01 \\
\hline Total excl. PRC & 670.535 & $8.061^{a}$ & 1.202 & 0.624 & 0.093 \\
\hline
\end{tabular}

CAREC = Central Asia Regional Economic Cooperation, GDP = gross domestic product, PRC = People's Republic of China.

a Excluding the PRC if it is exporting or importing.

Source: International Monetary Fund (World Economic Outlook Database; http://www.imf.org/external/pubs/ft/weo/2017/01/weodata/weoselgr.aspx ; accessed June 2017); Authors' calculations.

\subsubsection{Summary}

The main empirical findings and implications from the estimated gravity models are as follows:

- The time taken at the importers' border is a more important factor to facilitate bilateral trade among the CAREC countries, compared to the time taken at the exporters' border. Much of the duration and cost of road activities at the CAREC border crossing points take place during customs clearing and waiting or queuing, among other activities at the crossing points. ${ }^{28} \mathrm{It}$ is usually the case that duration and cost at inbound border crossing points tend to be larger than those at the outbound points. This suggests that potential targeted areas for further improvement should consider the time taken during customs clearing and waiting and queueing at the border crossing points of importers.

- More specifically, the model suggests that a 10\% reduction in time at the importers' border leads to an increase in intra-CAREC trade of 2\%-3\%. This amounts to an increase in intraregional trade of \$1.4 billion.

These findings are encouraging in that the CPMM TFIs, particularly TFI1, are quite accurate in representing the performance of CAREC's trade facilitation at the border. Despite the recent recognition of the limited achievement in trade facilitation in the CAREC region, ${ }^{29}$ the findings support the usefulness of the CPMM TFIs, and even suggest which indicators should be highlighted. Indeed, trade expansion, as one of the CAREC's mandates, can be achieved by trying to reduce the time taken at the importers' borders, as the empirical evidence suggests.

28 Border security/control; customs clearance; health/quarantine; phytosanitary; veterinary inspection; visa/immigration; State Traffic Inspectorate (GAI)/traffic inspection; police checkpoint/stop; transportation inspection; weight/standard inspection; vehicle registration; emergency repair; escort/convoy; loading/unloading; road toll; waiting/queuing.

29 CAREC 2020 Midterm Review (2016a) states that "Progress has been made in some areas of trade facilitation, but this has not yet effectively been translated into results on the transport corridors. The CPMM indicators show an improvement between 2014 and 2015, but compared with the 2010 baseline figures there has been little improvement in performance indicators. Due to the close link between transport infrastructure and border crossings, the limited achievements in trade facilitation have likely had a negative impact on the effectiveness of investments in transport infrastructure." 
The simulation exercise, however, reveals that the enhanced trade facilitation taking place only at the border crossing points may not suffice to bring about broader economic impacts in the CAREC economies. One potential explanation for the limited economic impact of time taken at the border is that the behind-the-border issues, while not fully captured in the CPMM measures, such as structural reforms including standard agencies, SPS laboratory capacity, trade-facilitation-related regulations would also be relevant measures in determining the trade flows in the CAREC countries. It is also essential to have a certain level of integration within CAREC countries to guarantee complementarity between soft and hard infrastructure, not only within the countries, but also with all other transit countries. Such complementarity ensures efficiency of goods movement from the country of origin, transit countries, and country of destination. 


\section{CHALLENGES AND THE WAY FORWARD*}

With the entry into force of the WTO TFA, which focuses on conventional trade facilitation measures, the challenge is putting the Agreement into practice. Developing and least developed countries are at various stages of setting up trade facilitation measures, with the cost of implementation differing in accordance with the measure being considered and the country circumstances. For trade facilitation to drive inclusive growth and poverty reduction, it must enable not only countries in different stages of development, but also different industries and enterprises.

Implementing facilitation measures is by nature more challenging than implementing physical infrastructure projects. For example, the impact of delays is greatest on routes crossing multiple borders. But the measures that reduce delays are complex and difficult to implement due to multiple layers of agents and nations. A key challenge is thus to adopt a more integrated approach to transport and trade facilitation that improves efficiency alongside new physical infrastructure.

The success of subregional programs - that serve as mutually beneficial platforms for formulating reform policies (similar to the one-vessel scheme of the Pacific)—rests exclusively with the group's member countries. Institutional coordination is essential for successful trade facilitation. Implementing trade facilitation requires coordinated efforts of both public and private stakeholders involved in multiple dimensions of trade and transaction activities. Commitment and consistency are required-for all stakeholders on policies, systems, and institutions. Improving the business climate and governance are critical prerequisite to maximize trade facilitation results. Sustaining institutional changes requires a longterm commitment from all national governments involved in subregional programs. ${ }^{30}$

The assessment from the 2017 global survey on trade facilitation and paperless trade confirms that most countries in the region are actively engaged in implementing measures to improve transparency, enhance interagency coordination and cooperation, and streamline fees and formalities associated with trade. While customs services in virtually all countries have been actively developing paperless systems to speed up clearance while improving control, nearly $40 \%$ of these economies are also working on more advanced national multiagency paperless systems, such as national electronic single windows.

However, implementing cross-border (bilateral, subregional, or regional) paperless trade systems remains mostly at the pilot stage. This is because: (i) many developing countries are at an early stage of developing paperless systems and that, (ii) more advanced countries have paperless systems not sufficiently harmonized with each other. Given the large potential benefits associated with implementing nextgeneration trade facilitation measures, ${ }^{31}$ countries from all groups must work together to develop the legal and technical protocols needed for the seamless exchange of regulatory and commercial data and documents. Some bilateral work has been done as well as cooperative efforts in several Asian subregions (in ASEAN as part of the ASEAN Single Window initiative, for example).

Implementation of trade facilitation and paperless trade measures will bring substantial benefits to the countries in Asia and the Pacific. The impact assessment of trade facilitation implementation on reducing trade costs in Asia and the Pacific reveals that implementation of binding and nonbinding WTO TFA measures results in a 5\% reduction in trade costs, on average, under a partial implementation scenario,

\footnotetext{
Chapter 4 draws mostly on ESCAP (2015), and the latest data available were updated or added.

30 In CAREC, for instance, countries need to revitalize and strengthen national joint transport and trade facilitation committees. These are considered critical for the effective coordination and implementation of CAREC transport and trade-facilitation initiatives at the national level.

31 See ESCAP (2014) at http://www.unescap.org/resources/estimating-benefits-cross-border-paperless-trade
} 
and an 9\% reduction under the more ambitious full implementation scenario. Under a WTO TFA + scenario, where paperless and cross-border paperless trade measures not included in the WTO TFA are implemented, the average trade cost reduction across countries increases to more than $16 \%$. Similarly, impact assessments of corridor performance on increasing trade in the CAREC region shows that average time (hours) taken at a border crossing point is a more significant factor than average costs (US dollar) incurred in determining the bilateral trade flows. The trade flow model implies that a $10 \%$ reduction in time at the importers' border leads to an increase in intra-CAREC trade of $2 \%-3 \%$, amounting to an increase in intraregional trade of $\$ 1.4$ billion.

Moving forward, digitalization can offer great potential to improve trade facilitation implementation and further reduced trade costs. Figure 13 shows implementation of trade facilitation as a step-by step process, based on the groups of measures included in this survey. Trade facilitation begins with the setting up of the institutional arrangement needed to prioritize and coordinate implementation of trade facilitation measures. The next step is to make the trade processes more transparent by sharing information on existing laws, regulations, and procedures as widely as possible and consulting with stakeholders when developing new ones. Designing and implementing simpler and more efficient trade formalities is next. The reengineered and streamlined processes may first be implemented based on paper documents, but can then be further improved through information and communications technology and the development of paperless trade systems. ${ }^{32}$

\section{Figure 13: Moving up the Trade Facilitation Ladder Toward Seamless International Supply Chains}

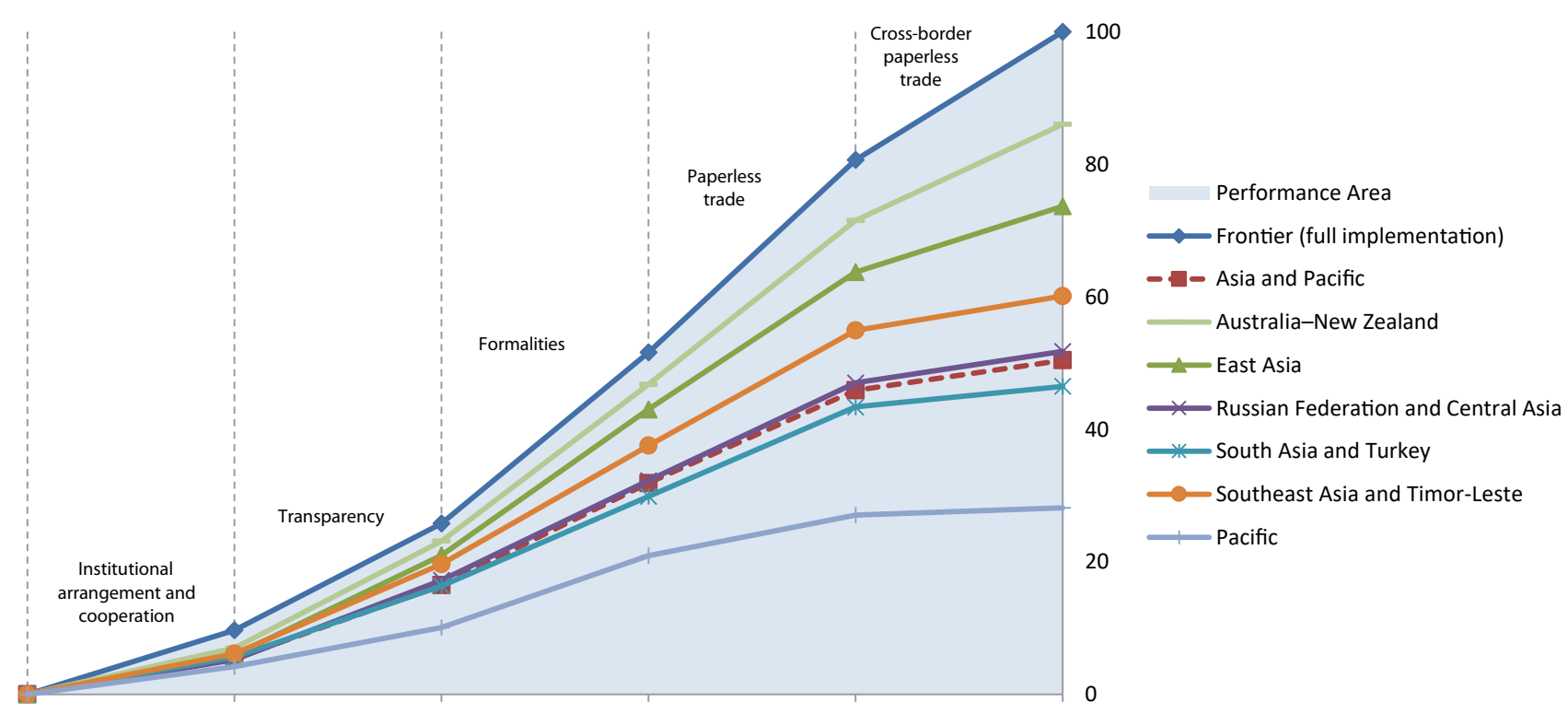

Note: The figure shows cumulative trade facilitation implementation scores of Asia and Pacific subregions for five groups of trade facilitation measures included in the survey. Full implementation of all measures $=100$.

Source: United Nations Regional Commissions. 2017.

To this end, the countries in Asia and the Pacific should not only continue to implement the TFA-related measures, but also need to gradually move towards digital trade facilitation. In this respect, the Framework Agreement on Facilitation of Cross-Border Paperless Trade in Asia and the Pacific under the auspices of ESCAP can be a good start. Complementing the WTO TFA, the Agreement provides a unique opportunity for member states to adopt the framework for cross-border paperless trade and facilitate the operation of single window systems. Negotiated as an inclusive and flexible intergovernmental platform to enable the electronic exchange of trade-related data and documents across borders among Parties, the Framework Agreement is set to benefit all parties regardless of their current state of implementation of paperless trade. Therefore, all countries in the region are encouraged to become a party of the treaty as soon as possible to take advantage of what the party offers, especially in terms of access to capacity building and technical assistance.

32 This step-by-step process is inspired from and generally consistent with the UN/CEFACT step-by-step approach to trade facilitation towards a single window environment. 


\section{APPENDIX}

\section{Nature and Relationships between Selected Trade Facilitation Measures Considered and the World Trade Organization Trade Facilitation Agreement Provisions ${ }^{\mathrm{a}}$}

\begin{tabular}{|c|c|c|}
\hline Trade Facilitation Measure & Corresponding WTO TFA Article & $\begin{array}{l}\text { Binding or Non-Binding Nature of } \\
\text { the WTO TFA Article }\end{array}$ \\
\hline \multicolumn{3}{|l|}{ Institutional arrangement } \\
\hline $\begin{array}{l}\text { 1. Establishment of a national trade } \\
\text { facilitation committee or similar body }\end{array}$ & $\begin{array}{l}\text { Section 3, Article 23: Institutional } \\
\text { Arrangements }\end{array}$ & Binding \\
\hline $\begin{array}{l}\text { 31. Cooperation between agencies on } \\
\text { the ground at the national level }\end{array}$ & $\begin{array}{l}\text { Section 1, Article 8: Border Agency } \\
\text { Cooperation }\end{array}$ & Binding \\
\hline
\end{tabular}

\section{Transparency}

2. Publication of existing import-export Section 1, Article 1.2: Information regulations on the Internet

3. Stakeholder consultation on new draft regulations (prior to their finalization)

4. Advance publication/ notification of new regulation before their implementation (e.g., 30 days prior)

5. Advance ruling (on tariff classification)

9. Independent appeal mechanism (for traders to appeal Customs and other relevant trade control agencies' rulings)
Section 1, Article 2: Opportunity to Comment, Information Before Entry into Force, and Consultations

Section 1, Article 2.1: Opportunity to Comment and Information Before Entry into Force

Section 1, Article 3: Advance Rulings

Section 1, Article 4: Procedures for Appeal and Review
Non-binding

(Phrasing: shall, to the extent practicable and in a manner consistent with its domestic law and legal system)

\section{Non-binding}

(Phrasing: shall, to the extent practicable and in a manner consistent with its domestic law and legal system)

Non-binding

(Phrasing: shall, to the extent practicable and in a manner consistent with its domestic law and legal system)

Binding

Binding

\section{Formalities}

6. Risk management (as a basis for deciding whether a shipment will be or not physically inspected)

Section 1, Article 7.4: Risk Management

Non-binding

(Phrasing: shall, to the extent possible)

7. Pre-arrival processing

Section 1, Article 7.1: Pre-arrival

Binding Processing

8. Post-clearance audit

Section 1, Article 7.5: Post-Clearance Audit
Binding 


\begin{tabular}{|c|c|c|}
\hline Trade Facilitation Measure & Corresponding WTO TFA Article & $\begin{array}{l}\text { Binding or Non-Binding Nature of } \\
\text { the WTO TFA Article }\end{array}$ \\
\hline $\begin{array}{l}\text { 10. Separation of Release from final } \\
\text { determination of customs duties, taxes, } \\
\text { fees and charges }\end{array}$ & $\begin{array}{l}\text { Section 1, Article 7.3: Separation of } \\
\text { Release from Final Determination } \\
\text { of Customs Duties, Taxes, Fees and } \\
\text { Charges }\end{array}$ & Binding \\
\hline $\begin{array}{l}\text { 11. Establishment and publication of } \\
\text { average release times }\end{array}$ & $\begin{array}{l}\text { Section 1, Article 7.6: Establishment and } \\
\text { Publication of Average Release Times }\end{array}$ & $\begin{array}{l}\text { Non-binding } \\
\text { (Phrasing: members are encouraged) }\end{array}$ \\
\hline $\begin{array}{l}\text { 12. Trade facilitation measures for } \\
\text { authorized operators }\end{array}$ & $\begin{array}{l}\text { Section 1, Article 7.7: Trade Facilitation } \\
\text { Measures for Authorized Operators }\end{array}$ & Binding \\
\hline 13. Expedited shipments & $\begin{array}{l}\text { Section 1, Article 7.7: Expedited } \\
\text { Shipments }\end{array}$ & Binding \\
\hline $\begin{array}{l}\text { 14. Acceptance of paper or electronic } \\
\text { copies of supporting documents } \\
\text { required for import, export or transit } \\
\text { formalities. }\end{array}$ & $\begin{array}{l}\text { Section 1, Article 10.2: Acceptance of } \\
\text { Copies }\end{array}$ & $\begin{array}{l}\text { Non-binding } \\
\text { (Phrasing: shall endeavor to accept) }\end{array}$ \\
\hline
\end{tabular}

\section{Paperless trade facilitation}

15. Electronic/automated Customs

System (e.g., ASYCUDA)

16. Internet connection available to

Customs and other trade control agencies at border-crossings

17. Electronic Single Window System

18. Electronic submission of Customs declarations

21. Electronic Submission of Air Cargo Manifests

22. Electronic Application and Issuance of Preferential Certificate of Origin

\section{E-Payment of Customs Duties and Fees}

\section{$\cdots$}

\section{Section 1, Article 10.4: Single Window}

Non-binding

(Phrasing: shall endeavor to establish)
Section 1, Article 7.2: Electronic Payment

Non-binding

(Phrasing: shall, to the extent practicable)

$\ldots=$ not.applicable.

Note: The appendix presents justifications for classing World Trade Organization Trade Facilitation Agreement (WTO TFA) measures as binding or nonbinding.

${ }^{a}$ Measures which are binding under the WTO TFA correspond to group (a) of TF measures in the counterfactual analysis presented in the report.

Group (b) consists of the measures in group (a) and nonbinding WTO TFA measures. Finally, group (c) include all measures under groups (a) and

(b) and paperless trade measures.

Source: ESCAP. 2014. 


\section{REFERENCES*}

Asian Development Bank (ADB) and ADB Institute. 2015. Pacific Opportunities: Leveraging Asia's Growth. Manila.

_- 2011. The Greater Mekong Subregion Economic Cooperation Program Strategic Framework 2012-2022. Manila.

-_- 2012. CAREC 2020: A Strategic Framework for the Central Asia Regional Economic Cooperation Program 2011-2020. Manila.

-_- 2013. GMS Regional Investment Framework 2013-2022. Manila.

-_- 2014a. SASEC Trade Facilitation Strategic Framework 2014-2018. Manila.

-_- 2014b. Central Asia Regional Economic Cooperation Corridor Performance Measurement and Monitor: A Forward-Looking Retrospective. Manila

- - . 2015a. Energy Strategy and Work Plan (2016-2020) for Regional Cooperation in the Energy Sector of CAREC Countries. Background paper for the CAREC Senior Officials' Meeting. Ulaanbaatar. 23-25 September 2015.

——_. 2015b. TTF Newsletter. https://www.adb.org/sites/default/files/publication/179782/ttf-01.pdf

_- - 2016. Asian Economic Integration Report 2016. Manila

- - 2017a. Trade Facilitation for a More Inclusive and Connected Asia and Pacific Region: Progress and Way Forward. Manila.

- - 2017b. Presentation Summary for Trade Facilitation in the Pacific at the Regional Workshop on Promoting Connectivity through Trade Facilitation and Aid for Trade (March 2017). Manila.

-_-.2017c. Asian Development Outlook 2017: Transcending the Middle-Income Challenge. Manila.

ADB and CAREC. 2014. CAREC Transport and Trade Facilitation Strategy 2020. Manila.

ADB and ESCAP. 2013. Designing and Implementing Trade Facilitation in Asia and the Pacific: 2013 Update. Manila. https://aric.adb.org/pdf/Trade_Facilitation_Reference_Book.pdf

Anderson, J.E. and E. Van Wincoop. 2003. Gravity with Gravitas: A Solution to the Border Puzzle. American Economic Review. 93 (1): pp.170-192.

Arnold, J., 2007. The Role of Trade Facilitation in Export Growth. Chapter 8 of SAR Integration. World Bank, Washington, D.C.

Arvis, J.-F., Y. Duval, B. Shepherd, and C. Utoktham. 2013. Trade Costs in the Developing World: 1995-2010. Policy Research Working Paper 6309, World Bank, Washington, D.C.

Central Asia Regional Economic Cooperation (CAREC). 2016a. CAREC 2020 Midterm Review. Manila. http://www.carecprogram.org/uploads/docs/CAREC-Publications/2016-CAREC-2020-MTR.pdf 


\section{References}

-_- 2016b. CPMM Annual Report 2015. Manila. http://cfcfa.net/images/downloads/CPMM_ AR20_15_\%20ENG.pdf

Daily Mirror. 2017. Can Sri Lanka Join Asian Supply Chains. 26 January. http://www.dailymirror.lk/article/ Can-Sri-Lanka-join-Asian-supply-chains--122750.html\#sthash.mQiMCLWO.dpuf

De Dios, L. C. (2009). The Impact of Information Technology in Trade Facilitation on Small and Medium Enterprises in the Philippines. Asia-Pacific Research and Training Network on Trade.

De Sousa, J., 2012. The Currency Union Effect on Trade Is Decreasing Over Time. Economics Letters 117 (3): pp. 917-920.

Deutsche Gesellschaft für Internationale Zusammenarbeit [GIZ]. 2011. Transport and Logistics Facilitation as an Effective Means of Promoting Trade and Regional Integration within the SADC. Working Paper, GIZ, Bonn.

Duval, Y. and C. Utoktham. 2014, Enabling Participation of SMEs in International Trade and Production Networks: Trade Facilitation, Trade Finance and Communication Technology. ARTNeT Working Paper Series No. 146, June 2014, ESCAP, Bangkok.

Economic and Social Commission for Asia and the Pacific (ESCAP). 2014. Estimating the Benefits of CrossBorder Paperless Trade. ESCAP, Bangkok. http://www.unescap.org/sites/default/files/Benefits\%20of\%20 Cross-Border\%20Paperless\%20Trade.pdf

-_- 2015. Trade Facilitation and Paperless Trade: State of Play and the Way Forward for Asia and the Pacific. ESCAP, Bangkok. http://www.unescap.org/resources/trade-facilitation-and-paperless-trade-stateplay-and-way-forward-asia-and-pacific

-_- 2016. Asia-Pacific Trade and Investment Report 2016: Recent Trends and Developments. ESCAP, Bangkok. http://www.unescap.org/publications/asia-pacific-trade-and-investment-report-2016recent-trends-and-developments

ESCAP and ADB. 2014. Towards a National Integrated and Sustainable Trade and Transport Facilitation Monitoring Mechanism: BPA+. ST/ESCAP/2683. Bangkok: www.unescap.org/resources/towardsnational-integrated-and-sustainable-tradeand-transport-facilitation-monitoring

Farhad, M. (2014). Trade Facilitation Reforms and Development and the Case of Bangladesh. Multi-Year Expert Meeting on Transport, Trade Logistics and Trade Facilitation. Geneva: UNCTAD.

Kituyi, M. 2016. Why Trade Matters. SDGs: The People's Agenda. 1 March. http://www.sustainablegoals.org. uk/why-trade-matters/

Lendle, Andreas, Marcelo Olarreaga, Simon Schropp, and Pierre-Louis Vézina. 2016. There Goes Gravity: eBay and the Death of Distance. Economic Journal, Royal Economic Society 126 (591): pp. 406-441.

Lim, A.H., P. Apaza, and A. Horj. 2017. Trade and Sustainable Development Goals (SDGs): How Can Trade in Education Services Contribute to the SDGs? ADBI Working paper series no. 697, ADBI, Tokyo. https://www.adb.org/sites/default/files/publication/234541/adbi-wp697.pdf

Organisation for Economic Co-operation and Development (OECD). 2005. The Costs and Benefits of Trade Facilitation. OECD Policy Brief, October 2005. http://www.oecd.org/trade/facilitation/35459690.pdf

SASEC Secretariat. 2016. SASEC Program: Operational Plan 2016-2025. Manila.

Syed S. H., U. D. September 2009. Impact of information technology in trade facilitation on small and medium-sized enterprises in Bangladesh. Asia- Pacific Research and Training Network on Trade. 
Tanabe, S., R. Shibasaki, and H. Kato. 2016. Impact Assessment Model of International Transportation Infrastructure Development: Focusing on Trade and Freight Traffic in Central Asia. Asian Transport Studies 4 (1): pp. 159-177.

United Nations Centre for Trade Facilitation and Electronic Business (UN/CEFACT). 2017. Establishment of a Trade and Transport Facilitation Monitoring Mechanism. https://www.unece.org/fileadmin/DAM/ cefact/recommendations/rec42/ECE_TRADE_C_CEFACT_2017_8E_R1_Rec42.pdf

United Nations Development Programme (UNDP). 2014. Global Event of Landlocked Developing Countries and Transit Countries on Trade and Trade Facilitation: Trade, Trade Facilitation and Transit Transport Issues for Landlocked Developing Countries. Joint publication by UNDP, United Nations Conference on Trade and Development, UN Office of the High Representative for the Least Developed Countries, Landlocked Developing Countries and Small Island Developing States, and Mission of Paraguay, Geneva.

United Nations Economic Commission for Europe (UNECE). 2012. Trade Facilitation - Principles and Benefits. UNECE, Geneva. http://tfig.unece.org/details.html

United Nations Network of Experts for Paperless Trade and Transport in Asia and the Pacific (UNNExT). (2010). Towards a Single Window Trading Environment: Best Practice in Single Window Implementation: Case of Singapore's TradeNet. http://www.unescap.org/sites/default/files/brief2.pdf

-_- 2011. Towards a Single Window Trading Environment: Japan's Development of a Single Window - Case of NACCS. http://www.unescap.org/sites/default/files/brief6.pdf

_- - 2012. "Towards a Single Window Trading Environment: Developing a National Single Window for Import, Export, and Logistics in Thailand." http://www.unescap.org/tid/UNNExT/pub/brief8.pdf

_-_. 2014. Towards an Enabling Paperless Trade Environment: Smarter Food Greece. ESCAP. http://www.unescap.org/sites/default/files/brief10.pdf

- - 2015. Towards an Enabling Paperless Trade Environment: Electronic traceability of agricultural products in India: the case of GrapeNet. ESCAP. http://www.unescap.org/sites/default/files/Brief15.pdf

United Nations Regional Commissions. 2017. Trade Facilitation and Paperless Trade Implementation Survey 2017. https://unnext.unescap.org/content/global-survey-trade-facilitation-and-paperlesstrade-implementation-2017

World Trade Organization (WTO). 2011. Trade Facilitation Implementation Case Study Risk Management: New Zealand's Experience. Retrieved from https:/www.wto.org/english/tratop_e/tradfa_e/case_ studies_e/risk_m_nzl_e.doc

- - - 2015. World Trade Report 2015 - Speeding up trade: benefits and challenges of implementing the WTO Trade Facilitation Agreement. Available at https://www.wto.org/english/res_e/booksp_e/ world_trade_report15_e.pdf.

-_- 2016. World Trade Report 2016: Levelling the Trading Field for SMEs. Geneva: WTO. pp. 108-123. https://www.wto.org/english/res_e/booksp_e/world_trade_report16_e.pdf

-_- 2017. Trade Facilitation. WTO, Geneva. https://www.wto.org/english/tratop_e/tradfa_e/tradfa_e.htm

World Bank. 2017. Trade in Transition. Washington, D.C.: World Bank. https://openknowledge.worldbank. org/bitstream/handle/10986/26497/9781464811135.pdf

Yang, J. 2009. Small and Medium Enterprises Adjustments to Information Technology (IT) in Trade Facilitation: The South Korean Experience. Asia-Pacific Research and Training Network on Trade.

*ADB recognizes "South Korea" as the Republic of Korea. 


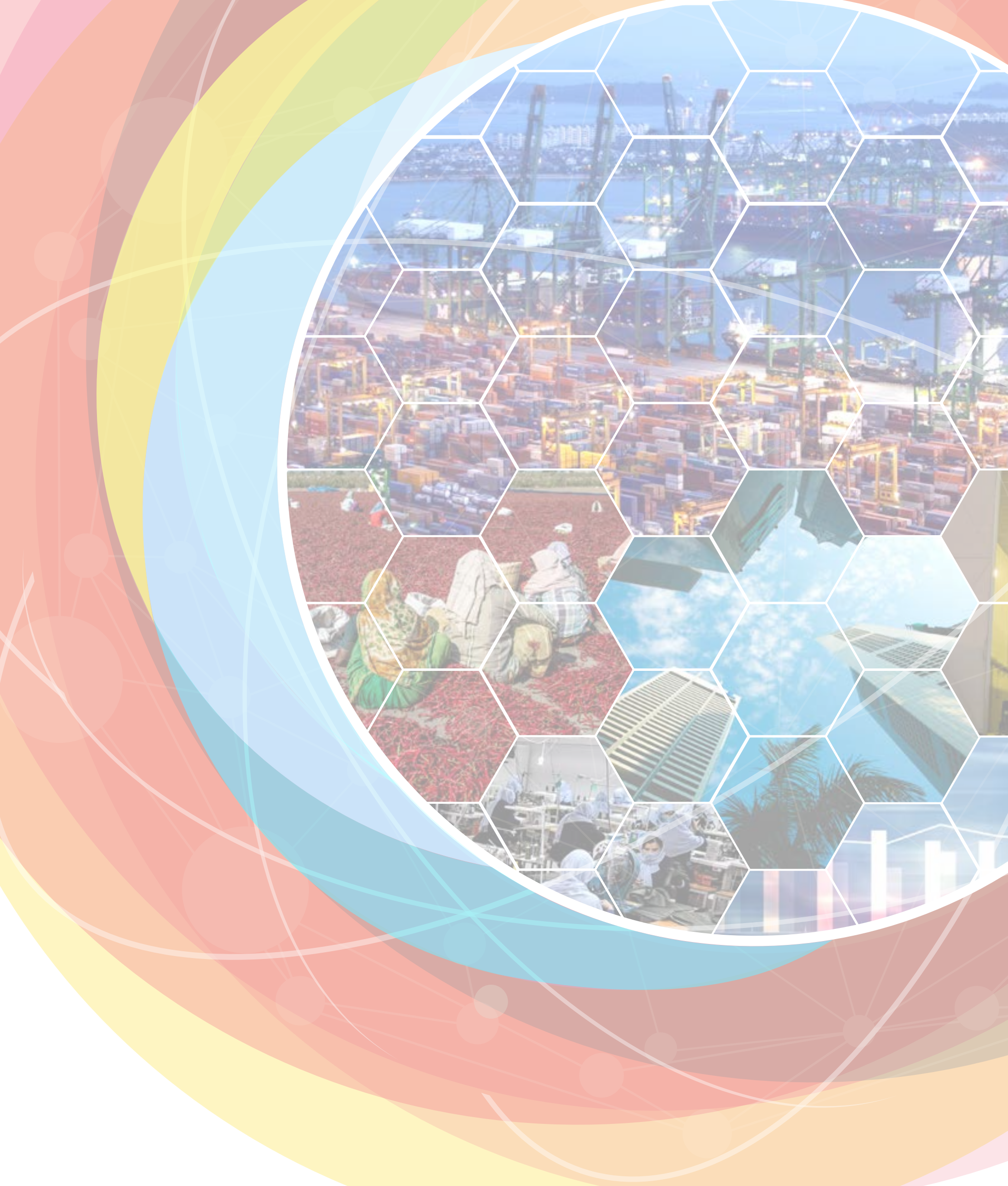




\section{Trade Facilitation and Better Connectivity for an Inclusive Asia and Pacific}

Trade facilitation increases trade flows, lowers trade cost, and ultimately contributes to sustainable and inclusive growth. This publication, jointly prepared by the Asian Development Bank and the United Nations Economic and Social Commission for Asia and the Pacific, reviews the state of play of trade facilitation and paperless trade in Asia and the Pacific. It investigates the evolution of trade costs in the region, examines trade facilitation and paperless trade implementation, and highlights the key initiatives and efforts in Central Asia, the Greater Mekong Subregion, South Asia, and the Pacific. It includes impact assessments of trade facilitation implementation and corridor performance on reducing trade costs and increasing trade.

\section{About the Asian Development Bank}

ADB's vision is an Asia and Pacific region free of poverty. Its mission is to help its developing member countries reduce poverty and improve the quality of life of their people. Despite the region's many successes, it remains home to a large share of the world's poor. ADB is committed to reducing poverty through inclusive economic growth, environmentally sustainable growth, and regional integration.

Based in Manila, ADB is owned by 67 members, including 48 from the region. Its main instruments for helping its developing member countries are policy dialogue, loans, equity investments, guarantees, grants, and technical assistance.

\section{About the United Nations Economic and Social Commission for Asia and the Pacific}

ESCAP is the regional development arm of the United Nations and serves as the main economic and social development center for the United Nations in Asia and the Pacific. Its mandate is to foster cooperation between its 53 members and 9 associate members. ESCAP provides the strategic link between global and country-level programs and issues. It supports governments of countries in the region in consolidating regional positions and advocates regional approaches to meeting the region's unique socioeconomic challenges in a globalizing world. The ESCAP office is in Bangkok, Thailand. 